\title{
O COMUSAN-SP e
}

\section{Os Paradigmas da Participação}

\author{
Roseli Lopes de Macedo Leal
}

Tese apresentada à

Faculdade de Saíde Pítrica daUtivesidadedeSãoPala,

Departamento de Prática de Saíde Púbtea, para obtencão

do Gudo de Daurar em Saide Pibica

Orientadora:Prof.DraMara Cocia Focesi Pecioni

São Paulo

2004 
FICHA CATALOGRÁFICA

\section{LEAL, Roseli Lopes de Macedo \\ O COMUSAN e os Paradigmas da Participação; São Paulo: 2004}

Tese (Doutorado em Saúde Pública)

Universidade de São Paulo

Faculdade de Saúde Pública

Bibliografia: p.

1. Conselho Municipal de Segurança Alimentar e

Nutricional de São Paulo - COMUSAN-SP 2. Paradigmas da Participação 3. Controle Social 4. Gestão Pública

Autorizada a reprodução total ou parcial, para fins pedagógicos ou científicos, desde que citada a fonte, resguardando os direitos da autora. E-mail: roseli_lealàyahoo.com.br

$$
44589 / 2004 \text { doc }
$$




\section{AGRADECIMENTOS}

\section{Agradeço}

Aos Conselheiros, do Conselho Municipal de Segurança Alimentar e Nutricional de São Paulo, que com dedicação e carinho se disponibilizaram para colaborar com esta Pesquisa.

À minha orientadora Prof ${ }^{a} \mathrm{Dr}^{\mathrm{a}}$ Maria Cecilia Focesi Pelicioni, pela paciência, atenção e dedicação.

A todas as amigas e amigos, pelo incentivo, apoio e carinho no decorrer da elaboração deste trabalho, em especial às (aos) companheiras (os) do Departamento de Inspeção Sanitária de Alimentos, da Secretaria Municipal de Saúde (ex Abastecimento), pelo caminhar conjunto, a dedicação ao trabalho e a disponibilidade de "arregaçar as mangas" e fazer acontecer. O mesmo para as (os) companheiras da Secretaria do COMUSAN-SP e aos queridos estagiários que me acompanharam (Erika e Rafael)

Aos meus pais, João e Maria, pelo amor incondicional e apoio durante toda minha caminhada.

Ao meu marido, Adalberto, pela paciência e carinho.

Aos meus filhos, Erika, Eduardo e Helena, pelo amor, carinho, paciência e auxilio nos trabalhos de digitação. 


\section{ÍNDICE}

RESUMO

SUMMARY

$\begin{array}{ll}\text { APRESENTAÇÃO } & 01\end{array}$

1 - INTRODUÇÃO

Paradigmas Dominate eEmergente 11

2 - REFERENCIAL TEÓRICO 21

2.1. Breve Histórico da Participação no Brasil 21

2.2. Participação no Contexto da Saúde 36

2.3. COMUSAN-SP 38

3 - OBJETIVOS 42

4 - METODOLOGIA 43

Metodologia Participativa $\quad 43$

4.1. Metodologia Qualitativa 44

4.2. Método da Observação Participante 48

4.3. Metodologia para Análise do Material 49

Análise de Conteúdo $\quad 49$ 
5.4. Dimensão: Processos / Cultura de Participação

6- CONCLUSÃO

7 - CONSIDERAÇÕES FINAIS

8 - REFERÊNCIAS

\section{ANEXOS}

01 - I Fórum sobre Democracia participativa

02 - Roteiro de Entrevista

03 - Categorização Preliminar de Dimensões e Categorias

04 - Tratado das ONGs de Segurança Alimentar - Rio 92

05 - Carta de Consentimento livre e esclarecido

06 - Decreto No 42.862, de 13 de Fevereiro de 2003

07 - Instituições participantes da $1^{a}$ Gestão do COMUSAN-SP

08 - Tabela A: Comissão Executiva da $1^{\mathrm{a}}$ Gestão do COMUSAN-SP

09 - Tabela B: Plano de Metas do COMUSAN-SP - 2003

10 - Propostas da I Conferência Municipal de Segurança 
12 - Consolidado das Propostas - II Conferência Municipal

de Segurança Alimentar e Nutricional de São Paulo

13 - Tabela C - Conselheiros participantes das reuniões do COMUSAN-SP, 2002

14 - Tabela D - Conselheiros participantes das reuniões do COMUSAN-SP, 2003 
LEAL, RLM. O COMUSAN-SP e os Paradigmas da Participação. São Paulo; 2003 [Tese de Doutorado - Faculdade de Saúde Pública da Universidade de São Paulo-USP]

O Conselho Municipal de Segurança Alimentar e Nutricional de São Paulo, COMUSAN-SP, o primeiro conselho municipal do gênero no pais, foi criado em Conferência, no ano de 2001.Ao estudá-lo, objetivou-se identificar como se deu a participação de seus membros e suas perspectivas, na $1^{2}$ gestão, 20012003 , tendo como referência os paradigmas da participação e os conselhos instituidos, como os de saúde. Para desenvolver a pesquisa utilizou-se a Metodologia Participativa, uma mescla de métodos e técnicas da metodologia qualitativa, com a participação direta de membros do Conselho para desenvolvela. A análise dos dados foi feita pelo método da Análise de Conteúdo, conforme BARDIN, através da categorização do material. As dimensões, categorias e indicadores abordaram a Estrutura, as Condições que Determinam a Participação, as Características e Dinâmicas da Participação e Processos e Cultura de Participação. Concluiu-se que a participação dos membros do COMUSAN-SP corresponde à fase de transição do paradigma dominante para o paradigma emergente, que preconiza a participação da sociedade na gestão pública com partilha de poder. Seus anseios convergem para a realização do principal objetivo do Conselho que é produzir políticas públicas de Segurança Alimentar e Nutricional para transformar as condições de vida da sociedade paulistana.

Palavras-chave: Conselho Municipal de Segurança Alimentar e Nutricional de São Paulo; controle social, participação popular, indicadores de participação social.. 
LEAL, RLM. COMUSAN-SP Participation Paradigms. São Paulo; 2003 [Thesis de doctor - Faculdade de Saúde Pública da Universidade de São Paulo-USP]

The Municipal Council of Nutricional and Food Security of Sao Paulo, COMUSAN-SP, the first council of this kind in Brazil, was created in a Conference in a 2001.By studying it, the objective was to identify how the Participation happened with its members and their perspectives, on the first administration, 2001-2003, using the references of participation paradigms and the councils have been created, as the health ones. To develop the search, it was used the Participate Methodology, a mix of methods and techniques of the qualitative method, with the direct participation of the Council members to develop it. The basis analysis was done with content analysis method, as BARDIN, by the categorization of material. The dimensions, categories and indicators were approached by the Structure, Participation Conditions, The Characteristics and Dynamics of the Participation, and The Process and Culture of the participation. It was concluded that Council members participation correspond from the dominant paradigm transition to the emergent paradigm, that commends society participation on public administration with power division. Their desires converge to produce Nutricional and Food Security Public Polices to transform life conditions of Sao Paulo society.

Key words: The Municipal Council of Nutricional and Food Security of Sao Paulo; social control, popular participation, social participation indicators. 


\section{OCOMUSANSPP OOS}

Paradigmas da Participação

\section{Apresentação}

"Todo ponto de vista é a vista de um po

Leonardc

A participação tem sido um tema importante para a democracia por todo o mundo. Em faça parte dos novos paradigmas da democracia ainda está em constante construção e su exaustivas discussões.

Tem-se vivenciado espaços de representação, vistos como democráticos e de al participação, mas que estão distantes de indicadores que atendam às necessidades de proposiç planejamento e, principalmente, deliberação por parte da sociedade (organizada ou não).

Os movimentos sociais são riquissimos em experiências, mas não costumam registrá-la não ser os mais organizados, como os ligados a conselhos. Seus participantes, na maior parte vezes, são capazes de fazer critica (e também autocritica) e construir seus próprios caminhos. $C$ vez mais buscam a defesa dos direitos do cidadão por todos os espaços que estiverem abertos. 0 estimula a investigação é o possivel motivo pelo qual os resultados nem sempre corresponden nivel de organização e potencial de intervenção que essas instituições ou movimentos têm.

$\mathrm{Na}$ dissertação de mestrado da autora foram estudadas as "Ações de Saúde em um Sindi، de Servidores Públicos Municipais", de São Paulo. A pesquisa realizada teve como objet Sindicato dos Servidores Públicos Municipais de São Paulo - SINDSEP, e as ações de saúde quais participou. $O$ intento foi analisar suas ações, entre 1989 e 1995, num contexto político sindi por diversas conjunturas. Dentro desses contextos foram focalizadas especificidades com participação do sindicato em espaços institucionais de representação (Conselho Municipal de Sa e outros dos quais a autora participou). Como conclusão ficou demonstrado que o Sindicato $t$ uma ação geral subordinada à conjuntura política e aos estilos diretivos que estiveram em ؛ 
mandatos. As ações de saúde "sobreviveram" na dependência das pessoas que estiveram envolvidas em cada momento, e de fatores externos que puderam dar suporte para tal (LEAL 1999a).

Relacionadas as experiências vividas no campo da saúde aos dados obtidos na pesquisa citada, surgiram algumas perguntas relativas à participação. Mesmo com todas as dificuldades que os movimentos, entidades e segmentos possam ter: $O$ que os representantes, atores sociais, pensam a respeito de participação? Que eficiência, eficácia e visibilidade têm a participação na vida ativa da sociedade? $O$ que pode ser feito, que caminhos percorrer para garantir acesso à participação com qualidade?

Além disso, a experiência de alguns anos de docência (ensino médio, superior e pósgraduação, lato senso) também contribuiu para que fosse percebido que as pessoas precisam de informação para o exercício pleno da cidadania (direitos, deveres e responsabilidades), não têm internalizado os conceitos de participação em sua essência e nem absorvem sua importância para a melhoria da própria qualidade de vida e a de suas futuras gerações, de maneira geral.

Em todos os eventos freqüentados, cujos participantes eram representantes de segmentos da sociedade civil, de trabalhadores e de governo, ouvimos queixas comuns a respeito de acesso às decisões e à participação plena. A mais recente observação desse fato ocorreu no I Fórum sobre Democracia Participativa, de 4 a 5 de julho de 2002, realizado pela Coordenadoria Especial do Orçamento Participativo (COP), do Projeto Democracia Participativa (Universidade Federal de Minas Gerais - UFMG) e Coordenadoria de Participação Popular (CPP) numa parceria entre o Municipio de Barcelona (Serviço de Participación Interactiva - SPI) e o Município de São Paulo para troca de experiências sobre participação, tendo como convidados representantes do Orçamento Participativo, das várias regiões da cidade de São Paulo e membros de Conselhos Municipais interessados. O Fórum contou com a contribuição de técnico espanhol que demonstrou a aplicação do método participativo Delibera.Info, Sistema Integral de Participació (aplicado pelo Conselho Municipal de Meio Ambiente e Sustentabilidade na Agenda 21 de Barcelona) cujos resultados (anexo-01) foram ao encontro do desejo de estudar possiveis queixas e encontrar possiveis soluções para as mesmas num Conselho em São Paulo. 
O COMUSAN-SP E OS PARADIGMAS DA PARTICIPAÇ̃̃O

Atualmente, a autora trabalha na Prefeitura do Município de São Paulo, na Secretaria Municipal de Abastecimento - SEMAB e tem tido a oportunidade de atuar junto ao Conselho Municipal de Segurança Alimentar e Nutricional de São Paulo - COMUSAN-SP.

A partir de uma revisão do referencial teórico relacionado à participação, bem como das experiências nos Conselhos de Saúde, dos quais participou, estudou o caso COMUSAN-SP para saber como se deu a participação e conhecer as facilidades e dificuldades encontradas para esse exercício no seu cotidiano. Além de buscar contribuir para soluções e progresso de seus objetivos sociais na luta por uma vida melhor e de mais qualidade para os cidadãos de São Paulo. 


\title{
1 - INTRODUÇÃO
}

\author{
... "Lembra-te que afinal te resta a vida, \\ com tudo que é insolvente e provisório \\ $e$ de que ainda tens uma saida: \\ entrar no acaso e anar o transitoriol"... \\ Carlos Pena Fitho
}

Os paradigmas da participação são resultantes de diferentes momentos sociais da história da humanidade. Nas últimas décadas o conceito de participação tem sido relacionado ao desenvolvimento social, referindo-se à participação em projetos, organizações ou comunidades. Num movimento crescente conjuga-se com os direitos do cidadão e parte imprescindivel de governos democráticos.

Vários autores apresentaram paradigmas de participação, definidos e contextualizados na geografia, no direito, nas ciências sociais, na história. Para melhor situar este tema, é preciso tratar também de conceitos como do próprio termo paradigma e outros conceitos como os de cidadania, educação e democracia associados ao estudo proposto.

KUHN (2003), fisico, foi o primeiro que intensificou a discussão sobre os paradigmas da natureza da ciência, no inicio da década de 1960. Considerou "paradigmas" as realizações científicas universalmente reconhecidas que, durante algum tempo, fornecem problemas e soluções que servem de modelo para uma comunidade cientifica. Segundo o autor, os paradigmas determinam a ciência normal (a que está sendo defendida no determinado momento que se discute) por algumas vias como: a grande dificuldade que se encontra para descobrir as regras que guiam tradições específicas dessa ciência normal; os cientistas nunca aprendem conceitos, leis e teorias de uma forma abstrata e isoladamente; uma nova teoria é sempre anunciada juntamente com suas aplicações a uma determinada gama concreta de fenômenos naturais; os problemas a enfrentar tornam-se cada vez mais complexos e os paradigmas orientam as pesquisas (direta ou indiretamente). Além das razões referidas, atribui uma prioridade aos paradigmas, a existência de grandes e pequenas revoluções, algumas afetando apenas os estudiosos de uma subdivisão de um 
campo de estudos. KUHN (2003) disse que na medida em que se avança na análise, vê-se quão cheias de consequências podem ser as diferenças de paradigma, pois a ciência normal não se propõe a descobrir novidades, quer em fatos ou teorias, e relutam às mudanças, incompativeis à vida da comunidade. Crises de paradigmas geram anomalias, que estudadas podem indicar novos caminhos e consequentemente novos paradigmas.

CAPRA (1982) traduziu paradigma como a visão de mundo e o sistema de valores que estão na base de uma cultura e dizem respeito à forma como as pessoas descrevem o mundo e todos os seus modos de pensar.

BOFF (1999) definiu paradigma como um conjunto de principios, idéias e valores compartilhados por uma comunidade servindo-lhes de referência e de orientação. Afirmou que a mudança de paradigma ocorre quando surge nova visão da realidade, o que se verifica cotidianamente.

SANTOS BS (2000) partiu da idéia de que os paradigmas sócio-culturais nascem, desenvolvem-se e morrem, sendo que ao morrer já trazem à luz um novo paradigma. Considerou que não se tem segurança de momentos exatos dessas passagens de um paradigma para outro e que alguns demoram longamente para se firmarem e que a transição paradigmática ocorre em movimentos, por nossas sociedades e culturas serem intervalares.

No dicionário LAROUSSE (1993) a participação foi definida como o ato ou efeito de participar, fazer saber, comunicar, anunciar; tomar parte em algum evento associar-se pelo sentimento, pensamento, solidarizar-se com, ter natureza semelhante ou qualidades comuns a alguém ou a algo. Também definiu cidadania como qualidade de cidadão, do indivíduo que goza dos direitos civis e políticos de um estado.

BENEVIDES (1994) resgatou a história e a etimologia da palavra, que vem de cidade (do romano antigo civitas e do grego antigo polis), na qual os cidadãos, membros livres da sociedade, se articulavam e participavam da vida pública, visando o interesse coletivo. Afirmou que, dessa forma, as palavras cidadania e cidadão referem-se à participação na vida da cidade entendida como espaço público para as decisões coletivas.Salientou que nessa democracia antiga havia clareza do termo cidadania pois consideravam cidadãos os membros ativos da sociedade, excluindo os escravos, as mulheres e os estrangeiros. Ressaltou que a concepção de cidadania tomou mais força na Revolução Francesa, quando a diferença entre o cidadão passivo e o ativo 
era justamente a participação em todos os assuntos de interesse comum. Lembrou que embora essa idèia tenha sido um dos grandes debates da revolução foi vencida pela idèia conservadora da democracia estritamente ligada à representação da nação (que mantinha o poder nas mãos de uma determinada classe, grupo, casta ou posição social).

A definição de cidadania foi sofrendo alterações ao longo dos tempos, hoje é abrangente a todos os individuos sem restrições. Reuniu o conjunto de direitos e liberdades politicas, sociais e econòmicas, estabelecido ou não pela legislação. A participação na sociedade fez parte da conquista da cidadania, foi considerada o Exercicio da Cidadania, como disseram os romanos e os gregos, a forma de fazer valer os direitos garantidos, exigida a observância dos direitos e cuidado para que não fossem desrespeitados (CNBB 1996).

FREIRE (2000) mencionou que os novos paradigmas da participação também trouxeram novos paradigmas para a educação como troca de saberes que, no enfrentamento de um problema concreto vivido pelos participantes, produz, neles e por eles, conhecimento, consciência, capacitação para a vida privada e pública. Assim, os cidadãos poderiam estar mais preparados para decidir sobre suas próprias vidas.

A participação sempre dependeu da conjuntura, e quase sempre ocorreu a partir de situações que suscitassem busca por melhor qualidade de vida, reivindicação de direitos, de igualdade de acesso e condições. A educação faz parte dos paradigmas da participação e é insubstituivel no processo em que se dê. É como realmente pode acontecer o empoderamento do cidadão, das comunidades (FASE s.n.t.).

SANTOS B S (2000) discutiu dois paradigmas sociais que elucidaram os caminhos escolhidos: o paradigma da ciência moderna: o conhecimento-regulação e o paradigma emergente: o conhecimento-emancipação. Ambos retratados numa "transição societal" entre a sociedade patriarcal, do paradigma dominante ou capitalista, do consumismo individualista e mercantil, da democracia autoritária, do desenvolvimento global, desigual e excludente e um novo paradigma ou conjunto de paradigmas, que está em formação e que pode permitir reinventar os caminhos da emancipação social. Tratou-se a participação social como um processo autônomo, ativo, próprio da sociedade, facilitada através das organizações, atores, movimentos e instituições da mesma sociedade de modo que houvesse presença em todos os âmbitos e dimensões de decisão. 
O COMUSAN-SP E OS PARADIGMAS DA PARTICIPAÇÃO

A sociedade, em todos os níveis e particularmente no local, foi desenvolvendo esforços participativos, que constituíram uma rica bagagem de realidades concretas. Estes esforços não foram convertidos em experiências disponiveis universalmente, por isso tenderam a se dispersar e a serem desperdiçados em seu enorme potencial como sementes de transformação. A evolução da participação social passou pela recuperação critica e sistemática dessas experiências, frente ao projeto maior de compreensão e transformação das relações sociais. Este processo construiu o conhecimento e serviu como uma ferramenta para materializar e viabilizar o exercício da participação social.

A participação social relacionou-se com um processo prévio e paralelo à democracia, $\mathrm{e}$, ao mesmo tempo, foi conseqüência e determinante desse. Entre participação social e democracia existe uma relação recíproca, pois a amplitude e legitimidade da democracia dependem da amplitude e força da participação social e vice-versa. Daí, a democracia e a participação social se expandirem e acontecerem concomitantemente.

A Participação Social é mais abrangente que a participação politica. Segundo TOURAINE (1989), não deve apenas reproduzir os mecanismos correntes da organização, ou simplesmente se adaptar aos mesmos, mas também estar apta a transformá-los e construí-los. A visão dos componentes da sociedade pressupõe que suas atividades e decisões orientem as estruturas sociais para o movimento (mudança) ou para a manutenção da ordem. Nessa perspectiva, a participação, em nenhum momento, deve visar à consolidação e a legitimação de estruturas sociais, mas sim, a transformação dos mecanismos que gerem as desigualdades. Deve-se pensar também na esfera decisória dos grupos sociais marginalizados de modo que estes contribuam para a modificação da lógica da sociedade, não tendo apenas como objetivo a incorporação pura e simples desses indivíduos, a qual ignoraria as possiveis contribuições advindas dos diferentes referenciais culturais e experiências dos mesmos. São as relações de dominação e poder que determinarão a receptividade, ou não, dessas contribuições.

Como já foi dito, os paradigmas da participação sempre estiveram associados à conjuntura em que aconteceram. SANTOS M (2000), em uma análise recente de conjuntura, demonstrou que o mundo capitalista, globalizante, promete igualdade, contudo, $21 \%$ da população mundial tem controlado $78 \%$ da produção mundial de bens e serviços e tem consumido $75 \%$ de toda a energia 
O CONUSAN-SP E OS PARADIGMAS DA PARTICIPAÇĀO

produzida; os trabalhadores do Terceiro Mundo, de setores importantes, tem recebido 20 vezes menos que trabalhadores da Europa e da América do Norte, na realização das mesmas tarefas e com a mesma produtividade; a divida dos paises pobres para com os paises ricos, aumentou vertiginosamente após os anos 80 , contribuindo para aumentar sua riqueza; no mesmo periodo, a alimentação para os paises de terceiro mundo foi reduzida em $30 \%$; mais pessoas morreram de fome no século $\mathrm{XX}$ que em qualquer outro momento da história e a distância entre ricos e pobres não para de aumentar.

\section{E quanto à promessa de liberdade?}

A resposta tem sido as constantes violações dos direitos humanos, mais de quinze milhões de crianças trabalham em regime de cativeiro, tem aumentado a violência em todos os sentidos, toda sorte de discriminações continua existindo, com cada vez maior número de manifestações explícitas (SANTOS M 2000).

\section{E quanto à promessa de Paz?}

Enquanto no século XVIII morreram 4,4 milhões de pessoas em 68 guerras, no século XX, 99 milhões de pessoas morreram em 237 guerras. Entre esses dois periodos a população mundial aumentou em 3,6 vezes enquanto a relação entre os números de mortos aumentou em 22,4 vezes. A dominação da natureza foi perversa, com destruições e crise ecológica, hoje um quinto da humanidade já não tem acesso à água potável (SANTOS M 2000).

A Organização Pan-americana de Saúde (OPAS 1993) também analisou a conjuntura ao discutir Participação e afirmou que no contexto da realidade daquele momento desenhava-se uma situação de crise multifacetada, que até hoje afeta todas as dimensões e aspectos da sociedade. Considerou haver crise das relações sociais, das formas de produção, das motivações, do coletivo e do individual, isto é, uma crise cultural. A vigência das crises se fez mais evidente, entre outros aspectos, na prevalência da não eqüidade materializada em múltiplas formas de exclusão, marginalização e abandono da maior parte da sociedade. Tudo isso frente ao extraordinário desenvolvimento tecnológico e com a enorme acumulação de riquezas em que tem se encontrado algumas nações ou alguns grupos sociais, como também frente ao fracasso de diferentes modelos de desenvolvimento e tentativas de melhorar a qualidade de vida das maiorias, reduzindo as diferenças e aumentando a autonomia dos povos e nações. A estrutura social que tem prevalecido, 
à medida que se define a situação econômica dos indivíduos, comunidades e nações, tem determinado $o$ acesso desigual aos benefícios sociais e às bases reais da participação social.

SILVA (2002), destacou a importância de alguns aspectos na análise da conjuntura para a participação social como o contexto político: o fortalecimento da sociedade civil, uma estrutura de classes mais flexível e com possibilidades nitidas de ascensão, bem como o surgimento de valores que permeassem o sentimento de coletividade no usufruto dos bens que possibilitam a existência de uma sociedade realmente democrática e aberta à participação, em que estivessem claros e garantidos os direitos da população. Não havendo essas condições, o engajamento de parcelas da sociedade geralmente só se dá com mobilização, atendendo aos interesses de governos totalitários e sufocando pensamentos e interesses contrários à ideologia do regime.

De acordo com MENDES (1996), na trama politico-institucional a importância do arranjo institucional e de suas conseqüências para a participação tem se reportado às determinações da Constituição Federal de 1988, que colocaram como complementares os órgãos da administração pública e os outros tipos de instâncias, visto que os primeiros resultaram da participação política, enquanto os outros puderam constituir-se no espaço da participação direta. Posto que hoje há uma orientação legal que contempla essa complementaridade, é imprescindivel que o poder municipal, o mais próximo dos cidadãos, operacionalize essas orientações, possibilitando o surgimento dos canais institucionalizados de participação.

TATAGIBA (2002) mostrou que a década de 1990 se caracterizou por um movimento muito intenso de atores e forças sociais envolvidos com o novo formato e desenho de políticas; que, o agravamento dos problemas sociais e a crise que caracterizou o poder público levaram ao questionamento da capacidade do Estado de responder às demandas colocadas. Sendo assim, o discurso da participação lançou exigências e buscou articular a democratização do processo com a eficácia dos resultados, a primeira como condição de realização da segunda. A sociedade poderia, assim, exercer um papel mais efetivo de fiscalização e controle, com efeito, direto sobre o próprio processo como um fator educacional na promoção da cidadania.

Hoje, a relevância dos âmbitos onde se localiza a participação também se estabelece nos processos decisórios, que ainda não consideram as novas orientações constitucionais e permanecem utilizando os mesmos mecanismos anteriores. A conseqüência mais provável é o 
fracasso das experiências de participação. Se os processos de decisão administrativa estiverem vinculados a regras pouco flexiveis, ou se as decisões possiveis das instâncias de participação puderem ser rediscutidas e reformuladas posteriormente por órgãos da administração pública, de pouco valerá a participação, que se levada a cabo resultará em uma "participação virtual", que não faz sentido. A relevância das decisões destinadas aos cidadãos pelo setor público quando da concepção dos órgãos de participação (ou quando da incorporação dos valores favoráveis à participação nos órgãos públicos) deve refletir o quanto realmente se abre para a população a possibilidade de interferir na definição dos objetivos da sociedade.

SILVA (2002), ainda salientou os niveis de decisão possiveis nas organizações, de acordo com a sua importância: a formulação da doutrina e da politica da instituição; determinação dos objetivos e estabelecimento de estratégias; elaboração de planos, programas e projetos; alocação de recursos e administração de operações; execução das ações; constatação dos resultados. Observou que há predisposição do corpo burocrático em assumir inteiramente os quatro primeiros niveis, ficando os dois últimos abertos a contribuições do povo. Dessa forma, fica claramente comprometido o exercício da cidadania e a visão dos membros da sociedade como construtores e transformadores ativos da mesma. Atribuiu ao setor público a incumbência de tornar-se mais permeável à interferência da sociedade, sem, no entanto, abdicar do direito que lhe foi investido, pelo voto, de propor as politicas e projetos pelos quais foram eleitos. $\mathrm{O}$ grande problema, que provoca questionamentos a respeito das políticas e projetos dos partidos, é que, como bem colocado por TOURAINE (1989), os partidos têm se orientado cada vez menos por ideologias (projetos políticos reais) e se transformado em agências de conquista de poder. Logo, a confiança em que os eleitos realmente possam cumprir o prometido decresce, urgindo então a necessidade de que a população garanta que as políticas propostas sejam executadas.

A capacidade de impacto da participação dos cidadãos tornou-se outro elemento de destaque conjuntural. Se as decisões reservadas à população se situarem em âmbitos pouco relevantes, como observado acima, a intervenção dos cidadãos nos aspectos realmente importantes não existirá, e o impacto da atuação da população ficará comprometido. Logo, a institucionalização de instâncias que promovam a aglutinação dos grupos sociais como atores participantes das decisões torna-se fundamental para que se passe de uma conjuntura em que a 
O COMUSAN-SP E OS PARADIGMAS DA PARTICIPAÇÃO

consulta à população se dá em fases irrelevantes para outra em que a influência da sociedade seja realmente decisiva.

\section{Paradigmas Dominante e Emergente}

Para destacar o antagonismo entre o Paradigma Dominante e o Paradigma Emergente, conforme a teoria de KUHN (2003), foi importante esmiuçar cada um deles.

\section{Paradigma Dominante}

SANTOS BS (2000) tratou o Paradigma Dominante como o modelo de racionalidade que presidiu à ciência moderna e que se constituiu a partir da revolução científica do século XVI e foi desenvolvido nos séculos seguintes basicamente no domínio das ciências naturais. Ainda que com alguns prenúncios no século XVIII, foi só no século XIX que este modelo de racionalidade se estendeu às ciências sociais emergentes (no século XVIII, lembrada a Declaração dos Direitos do Homem e do Cidadão, que inspirou profundas mudanças na visão de mundo e dos direitos humanos). Para CAPRA (1982), esse paradigma também percorreu várias culturas, por centenas de anos, como nos periodos da Revolução Científica do Iluminismo e da Revolução Industrial, incluindo a concepção do universo como um sistema mecânico composto de unidades materiais elementares. A concepção da vida em sociedade, como uma luta competitiva pela existência, e a crença no progresso material ilimitado, alcançada através do crescimento econômico e tecnológico, a despeito dos ideais da Revolução Francesa e das premissas de igualdade civil e liberdade individual - uma e outra foram muito revitalizadas pela desigualdade social que se consolidou no capitalismo, conforme delineou TRINDADE (1998), posto que a desigualdade nas condições econômico-sociais acabou anulando a liberdade, por mais que esta estivesse solenemente garantida e consagrada em nivel jurídico-formal.

Sendo um modelo global, a racionalidade científica é também um modelo totalitário, na medida em que nega o caráter racional a todas as formas de conhecimento que não se pautarem pelos seus princípios epistemológicos e pelas suas regras metodológicas. 
O COMUSAN-SP E OS PARADIGMAS DA PARTICIPAÇÃO

Como afirmou KUHN (2003), nesse paradigma o que não é "quantificável", é cientificamente irrelevante, o método científico ajuizou-se pela redução da complexidade. Para o autor, conhecer significa dividir e classificar e depois determinar relações sistemáticas entre o que já separou. As condições iniciais eram o reino da complicação, do acidente e onde seria necessário selecionar o que estabelece as condições relevantes dos fatos a observar; as leis da natureza seriam o reino da simplicidade e da regularidade, onde seria possivel observar e medir com rigor.

A crise do Paradigma Dominante, profunda e irreversível, foi mediada pela revolução científica (com Einstein e a mecânica quântica) e por especulações acerca desse paradigma. A identificação dos limites e das insuficiências estruturais do paradigma científico moderno foi o resultado da revolução e do grande avanço no conhecimento que ele propiciou. $\mathrm{O}$ aprofundamento do conhecimento permitiu ver a fragilidade dos pilares das teorias anteriores (KUHN 2003, SANTOS BS 2000, CAPRA 1982).

Outra importante contribuição para essa constatação foi a de CAPRA (1982) quando falou do progresso do conhecimento no campo da microfisica, da química e da biologia nos últimos trinta anos, principalmente a problematização do conhecimento científico e sua prática rumo ao conhecimento do próprio ser. A análise das condições sociais, dos contextos culturais, dos modelos organizacionais da investigação científica, antes apenas no campo da sociologia da ciência, agora em destaque na reflexão epistemológica.

Foram abertos os caminhos para o Paradigma Emergente e, como este sugeriu, para mudanças flutuantes de valores e seus efeitos sobre todos os aspectos da vida e da sociedade. Valores éticos absolutos, e padrões sobre-humanos de justiça, verdade e beleza; ainda, as representações dos conceitos espirituais (alma, Deus e outras crenças). 
O COMUSAN-SP E OS PARADIGMAS DA PARTICIPAÇÃO

\section{Paradigma Emergente}

Parte de um conhecimento retrospectivo para um futuro de imaginação, de construção coletiva, prudente, um Paradigma Social, como SANTOS BS (2000) o mencionou: o paradigma de uma vida decente, a partir de representações mais abertas, incompletas ou inacabadas do nosso tempo. As representações que a modernidade deixou no domínio da regulação (mercado, Estado e comunidade) passaram para o princípio da comunidade (marginalizada e esquecida pela regulação), no domínio da emancipação, a racionalidade estético-expressiva.

As duas principais dimensões desse paradigma foram a participação e a solidariedade. A participação, na esfera política, definida como parte da cidadania e da democracia representativa e a solidariedade, ainda na forma dominante, parte das politicas sociais do Estado-Providência. Ambas, sob esse paradigma, consideradas formas autônomas de saber, intimamente relacionadas. Saber este, do reconhecimento do outro, da intersubjetividade. O saber que, na transição paradigmática, consistiu na revalorização e reinvenção do conhecimento-emancipatório.

Para SANTOS BS (2000) os pressupostos metafísicos, os sistemas de crenças, os juízos de valor, não estiveram nem antes nem depois da explicação científica da natureza ou da sociedade. $\mathrm{O}$ conhecimento-emancipatório converteu-se num senso comum emancipatório, impondo-se ao preconceito conservador e ao conhecimento prodigioso e impenetrável, teve de ser um conhecimento prudente para aquela vida decente.

A reinvenção do senso comum foi incontornável dado o potencial desta forma de conhecimento para enriquecer a relação com o mundo. Apesar de o conhecimento do senso comum ser geralmente um conhecimento mistificado e mistificador, e apesar de na maioria das vezes ser conservador, possuiu uma dimensão utópica e libertadora que pode valorizar-se através do diảlogo com o conhecimento pós-moderno. O conhecimento-emancipação, ao tornar-se senso comum, não desprezou o conhecimento que produziu tecnologia, mas entendeu que tal como o conhecimento traduziu-se em autoconhecimento e o desenvolvimento tecnológico traduziu-se em sabedoria de vida (SANTOS BS 2000).

O novo senso comum foi construido a partir de representações mais inacabadas da modernidade ocidental: o princípio da comunidade, como visto anteriormente, nas suas duas 
O COMUSAN-SP E OS PARADIGMAS DA PARTICIPAÇÃO

dimensões, a solidariedade (dimensão ética) e a participação (dimensão política), e na racionalidade estético-expressiva (o prazer, a autoria e a artefactualidade discursiva). Esse paradigma também pressupôs um novo principio, o da responsabilidade (Santos BS 2000, mencionou que isso foi proposto por Hans Jonas, 1985). Esse principio residiu na preocupação com o outro, o ser humano, um grupo social, a natureza deve ser uma responsabilidade pelo futuro. Lembrou-se que aqui não há o principio da reciprocidade, que tanto a natureza quanto o futuro terão direitos sem ter deveres, que toda responsabilidade deve ser também coresponsabilidade, responsabilidade partilhada na quota de conseqüências. A redução da participação, no seu aspecto político, pode enfraquecer essa prática social. Quanto maior for o dominio da prática política na participação, maior a liberdade. Partindo desses pressupostos, Santos evocou Foucault para concluir a transição paradigmática do dominante para o emancipatório: todas as relações de poder são políticas - pressupondo que a participação seja instância de poder (SANTOS BS 2000).

CAPRA (1982), ao tratar do "novo paradigma", mencionou a transferência da concepção mecanicista da realidade para a holística, exemplificando com os movimentos sociais, aparecidos entre os anos de 1960 e 1970, que enfatizaram essa nova visão e deu força a mudança social: emergente visão sistêmica de vida, pensamento, consciência de evolução; a correspondente abordagem holística da saúde e da cura; a integração dos enfoques ocidental e oriental da psicologia e da psicoterapia; uma nova estrutura conceitual para a economia e a tecnologia; e uma perspectiva ecológica e feminista (que se contrapõe à visão sexista do movimento mecanicista), que foi espiritualizada em sua natureza essencial acarretando profundas mudanças em nossas estruturas sociais e politicas. Contrariando MARX (1987), afirmou que as transformações que ocorrem na sociedade não se esgotam em suas contradições internas. GRACIANO e ARZABE (1998) contribuíram com a observação, à luz do conceito dos direitos humanos, de que o individuo possui uma dignidade absoluta e irredutível que tem de ser defendida da sociedade ou do Estado; a autonomia do individuo exige que a sociedade esteja organizada de forma não hierárquica, como soma de individuos livres.

Bem cabe no paradigma emergente, a preocupação de REIGOTA (1999) que evocou os paradigmas da globalidade (pensamento global e ação local e pensamento local e ação global), no diálogo das culturas, saberes e gerações, como condições fundamentais da pós-modernidade de 
O COMUSAN-SP E OS PARADIGMAS DA PARTICIPAÇÃO

resistência. Concluiu que na difusão de encontro, misturas e sintese de culturas diferentes reside a possibilidade de oposição aos nacionalismos e etnicismos, que emergiram no final do século $\mathrm{XX}$ com enorme violência, trazendo implícitos os vícios de uma política internacional deliberadamente equivocada.

REIGOTA (1999) afirmou que a pós-modernidade de resistência à barbárie, em que a ecologia sofreu "simbiose" com os principios de eqüidade e de justiça, foi um dos argumentos de base e a educação, uma das condições fundamentais para sua efetivação; que a globalização (do espaço público e da vida privada) exigiu uma redefinição do papel e da participação de individuos, grupos sociais, estados nacionais e supranacionais. Complexa, a globalização alterou, num movimento crescente, as representações, a sociabilidade, a afetividade, as atividades profissionais cotidianas, elementos que formaram a base de uma nova cultura política de dimensão planetária.

\section{Posturas Paradigmáticas}

Têm acontecido transformações expressas em novas relações como antagonismos, confronto e oposição declarada, que tem caracterizado essas relações na resistência contra as imposições, opressões e investidas de hegemonização. Essas transformações têm ocorrido ao mesmo tempo em que o capitalismo e a ciência normal com seus paradigmas dominantes tem investido na manutenção de seus padrões. As posturas paradigmáticas se expressaram na medida em que ações para manter ou mudar paradigmas aconteceram.

Para SANTOS M (2000) a globalização tem provocado conseqüências perversas: o desemprego, a pobreza crescente, as classes médias perdendo qualidade de vida, os salários médios baixando, a fome o desabrigo e enfermidades epidêmicas (como a AIDS, em certas localidades). A crise do capitalismo exigiu novas definições e novos arranjos, pois tem estado em toda parte. Realizou-se concomitante em todo o mundo. A velocidade incontrolável dos acontecimentos tem provocado, a cada dia, desequilíbrios assustadores. A tirania do dinheiro e a tirania da informação fundiram-se em situações ameaçadoras. $O$ que deveria servir para o bem da humanidade como novas condições técnicas que permitissem a ampliação do conhecimento do planeta, dos objetos, das sociedades, se prestou a interesses e objetivos particulares, apropriados 
O COMUSAN-SP E OS PARADIGMAS DA PARTICIPAÇÃO

por muitos Estados que aprofundaram as desigualdades, dominaram, controlaram, subjugaram. As informações oferecidas muitas vezes foram "manipulatórias" (de forma planejada, alteraram o pensamento, o querer e as visões de mundo), a midia tem freqüentemente servido para induzir, enganar e controlar as pessoas em prol do consumo inconsciente da mercadoria global.

A informação, que deveria ser instrumento de mudança real, de maneira geral, não tem chegado às mãos da população integralmente. LEFĖVRE (2002) observou que quando se pensa em promoção de saúde (discutida mais adiante), uma das dimensões que deve ser considerada é a "socializadora", que tem difundido informação e que tem como eminência a garantia do fortalecimento das populações, base para o conhecimento-emancipatório, que favorece a autonomia para escolhas, condução dos próprios caminhos, gerência independente de vidas.

SILVA (1996), refletindo sobre o processo de comunicação entre sociedade e Estado, declarou que é preciso que as informações sobre as realizações do governo, relevantes para o público e as reivindicações da população, estejam sendo constantemente trocadas. Que será dessa forma que se construirá um diálogo permanente e horizontal, contribuindo para a qualidade das mensagens e aumentando a sua compreensão pelas partes envolvidas. A população passará a deter, então, maior controle sobre as ações do Estado, pois o processo de dialógico exposto acima trará, como consequêencia, uma maior transparência do setor público. Há facilidade em perceber a importância desse processo, pois somente com cidadãos informados e atentos aos acontecimentos e à evolução da administração pública se assegurará o alcance do ideal democrático, que pressupõe também uma população capaz de distinguir entre as alternativas a ela colocadas, aquela que melhor atenderá a seus interesses e aos de sua comunidade.

Outro obstáculo, fenômeno observado em diversos paises, tem sido o pouco interesse da sociedade pelos acontecimentos politicos e conseqüentemente pela participação nos mesmos.

A presença de dirigentes políticos dispostos a tornarem suas administrações mais transparentes e acessiveis às demandas sociais, bem como de servidores propensos a interagir mais frequientemente com a população é vital para o sucesso desse tipo de comunicação. A dúvida tem sido até que ponto os dirigentes tem desejado essa abertura maior da administração e não tem tido a intenção de manipular. Quanto aos servidores públicos, precisam de condições mínimas para que possam criar instrumentos criativos e eficazes de troca de informações entre Estado e 
OCOMUSAN-SP E OS PARADIGMAS DA PARTICIPAÇĀO

sociedade (SILVA 1996). A grande restrição nessa questão, como foi observado por JACOBI (1992b), não tem sido a elaboração de informações objetivas pelo poder público, a geração de informações jả acontece de modo razoável, seja por exigência da legislação, seja por orientações do executivo. Na verdade, o gargalo tem sido a distribuição da informação, ou seja, a necessidade de reformulação dos meios disponiveis e a criação de novas formas que atentem para a diversidade da capacidade de entendimento dos membros da sociedade, bem como para os interesses diferenciados encontrados na mesma como citado por LEFĖVRE (2002).

TANAKA e MELO (2001) propuseram que, dentro dos processos de investigação, o acesso à informação devesse ser facilitado e tivesse a preocupação de que, na medida em que se faça a investigação, de qualquer natureza, essa possa ser disseminada. Que, sem tal difusão, não se pode desenhar modelos de avaliação melhores e mais aprimorados do que se dispõe e sem os quais não se identifica instrumento simples e pragmático.

Nessa reflexão também cabe resgatar a importância do papel e da influência que a educação, a informação e a comunicação (FREIRE 1992) podem ter no processo de participação para fazer frente às desvantagens provocadas pela globalização massificante e às informações direcionadas.

Pela educação, formal e informal, com uma pedagogia libertadora como a proposta por FREIRE (2000), tanto homens quanto mulheres de diferentes etnias, têm tido oportunidade de participar de uma luta global transformadora das relações de poder e privilégios existentes em prol de equiidade, justiça social e liberdade da pessoa humana. Dessa forma será praticado o paradigma emergente, do conhecimento-emancipatório. Freire também se preocupou com a prática de uma política da diversidade e da auto-afirmação, junto com uma política cultural, mas, não como um simples fim em si mesma, e sim em relação a uma politica mais ampia, a da libertação e justiça social contra o campo de conflito mais complexo, das relações capitalistas de exploração, uma luta de preservação da história de vida das pessoas, o respeito às tradições, ao saber popular, ao ser humano (de todas as raças, credos, condições sociais, sexo, idade) nas suas escolhas, limitações e capacidade de relacionamento com o mundo.

BOFF (1999) também se referiu à educação como um processo coletivo, troca de saberes, como o saber popular contido nas tradições dos velhos, nas lendas e nas estórias dos índios, 
O COMLSAN-SP E OS PARADIGMAS DA PARTICIPAÇÃO

negros, mestiços, imigrantes, dos antepassados, confrontando e complementando com o saber crítico cientifico. Foi com esse tipo de educação que FREIRE (2000) e BOFF (1999) se preocuparam em valorizar, a mesma que o paradigma emergente tem defendido, a que dá autonomia ao cidadão para decidir sobre sua própria vida.

Mesmo que o cidadão estivesse motivado para a participação, esta poderia ser obstaculizada por uma educação deficiente, se não criou nele o hábito de participar. $\mathrm{O}$ cidadão poderia até identificar as razões que o levariam à participação, mas não conseguiria mudar o seu padrão de comportamento. Somente com o exercicio contínuo da participação, homens e mulheres conseguirão perceber a possibilidade não só de alterar seu comportamento, mas também de intervir na realidade que os cercam, transformando-a, a partir de suas reflexões e de suas ações (FREIRE 2000 e AMMAN 1977). Esse exercício contínuo depende fundamentalmente da criação de uma consciência crítica nos individuos, que permita reflexões acerca de si próprios e das atividades que desenvolvem, como colocado por AMMAN (1977).

Frente ao referencial trabalhado acima, a análise do contexto a partir dos paradigmas dominante e emergente proposta por SANTOS BS (2000) possibilitou um modelo de racionalidade que definiu a natureza teórica do conhecimento científico como decorrente dos pressupostos epistemológicos e de regras metodológicas definidas.

Retomando o paradigma cientifico no modelo totalitário, percebeu-se a negação do caráter racional a todas as formas de conhecimento que não se pautaram por seus princípios e regras. . Mesmo estando num novo momento da história a formação básica dos atores foi encontrada num momento histórico anterior, tendo assim a possibilidade de exercer influência nessa transição paradigmática clamando pelo novo paradigma científico e melhor observação dos fatos com uma nova visão de mundo. Os protagonistas desse novo modelo têm lutado contra as formas de dogmatismo e autoritarismo, abrindo novos caminhos. Além do conhecimento científico normal, o conhecimento do senso comum e as relações entre a natureza e a pessoa humana, nas idéias, presidem a observação e a experimentação, claras e simples, a partir das quais se pode ascender a um conhecimento mais profundo das naturezas, das pessoas e suas relações.

$O$ conhecimento-emancipação tem de converter-se num senso comum emancipatório: impondo-se ao preconceito conservador e ao conhecimento prodigioso e impenetrável, 
O COMUSAN-SP E OS PARADIGMAS DA PARTICIPAÇÃO

tem de ser um conhecimento prudente para uma vida decente. A reinvenção do senso comum é incontornável dado o potencial desta forma de conhecimento para enriquecer nossa relação com o mundo. Apesar de o conhecimento do senso comum ser geralmente um conhecimento mistificado e mistificador, e apesar de ser conservador, possui uma dimensão utopia e libertadora que pode valorizar-se através do diálogo com o conhecimento pós-moderno [sic] $O$ conhecimento-emancipação, ao tornar-se sensocomum, não despreza o conhecimento que produz tecnologia, mas entende que tal como o conhecimento deve traduzir-se em autoconhecimento, o desenvolvimento tecnológico deve traduzir-se em sabedoria de vida. (SANTOS BS 2000)

O novo senso comum, de acordo com a proposta de SANTOS BS (2000), deve ser construido a partir das representações mais inacabadas da modernidade ocidental, o princípio da comunidade, com as suas dimensões: a solidariedade (dimensão ética), a participação (dimensão política) e a racionalidade estético-expressiva (o prazer, a autoria e a artefactualidade discursiva).

Esse novo senso comum solidário deve pressupor uma nova ética: o principio da responsabilidade - em nossa época, cada vez mais dificil de determinar quem são os agentes, quais são as ações e quais as consequências, que residam na preocupação, no cuidado com o ser humano, com a natureza, na responsabilidade com o futuro. Desse novo senso comum solidário partimos para o senso comum participativo, um equilibrio entre a regulação e a emancipação. A regulação da política e uma prática social setorial, especializada e rigida na regulação da participação do cidadão: a participação autorizada, institucionalizada ou não, mas "repolitizada" globalmente para a vida coletiva; como diria Focault, lembrado por SANTOS BS (2000), todas as relações de poder são políticas, sendo esse um caminho para o cidadão comum fazer ou praticar política, a política da participação!

Segue, de forma sistematizada, no quadro abaixo, os condicionantes dos paradigmas dominante e emergente, tratados anteriormente, que norteiam a análise das dimensões de participação no contexto social, baseado em CAPRA (1982) e SANTOS BS (2000). 
O COMUSAN-SP E OS PARADIGMAS DA PARTICIPAÇÃO

TABELA 01 - Bases Paradigmáticas para análise de Paradigma da Participação baseado em CAPRA (1982) e SANTOS BS (2000)

\begin{tabular}{|c|c|}
\hline Paradigma Dominante & Paradigma Emergente \\
\hline $\begin{array}{l}\text { - Dominio das ciências naturais } \\
\text { - Concepção mecanicista } \\
\text { - Sistema mecânico composto de } \\
\text { unidades materiais elementares } \\
\text { - A vida em sociedade - competição } \\
\text { pela existência } \\
\text { - Progresso material ilimitado / } \\
\text { crescimento econòmico e tecnológico } \\
\text { - Desigualdade social - cap̧italismo } \\
\text { - Modelo totalitário (o qualitativo é } \\
\text { irrelevante) } \\
\text { - Metodologia cientifica - reducão da } \\
\text { complexidade (divisão, classificação e } \\
\text { sistematizacão) }\end{array}$ & 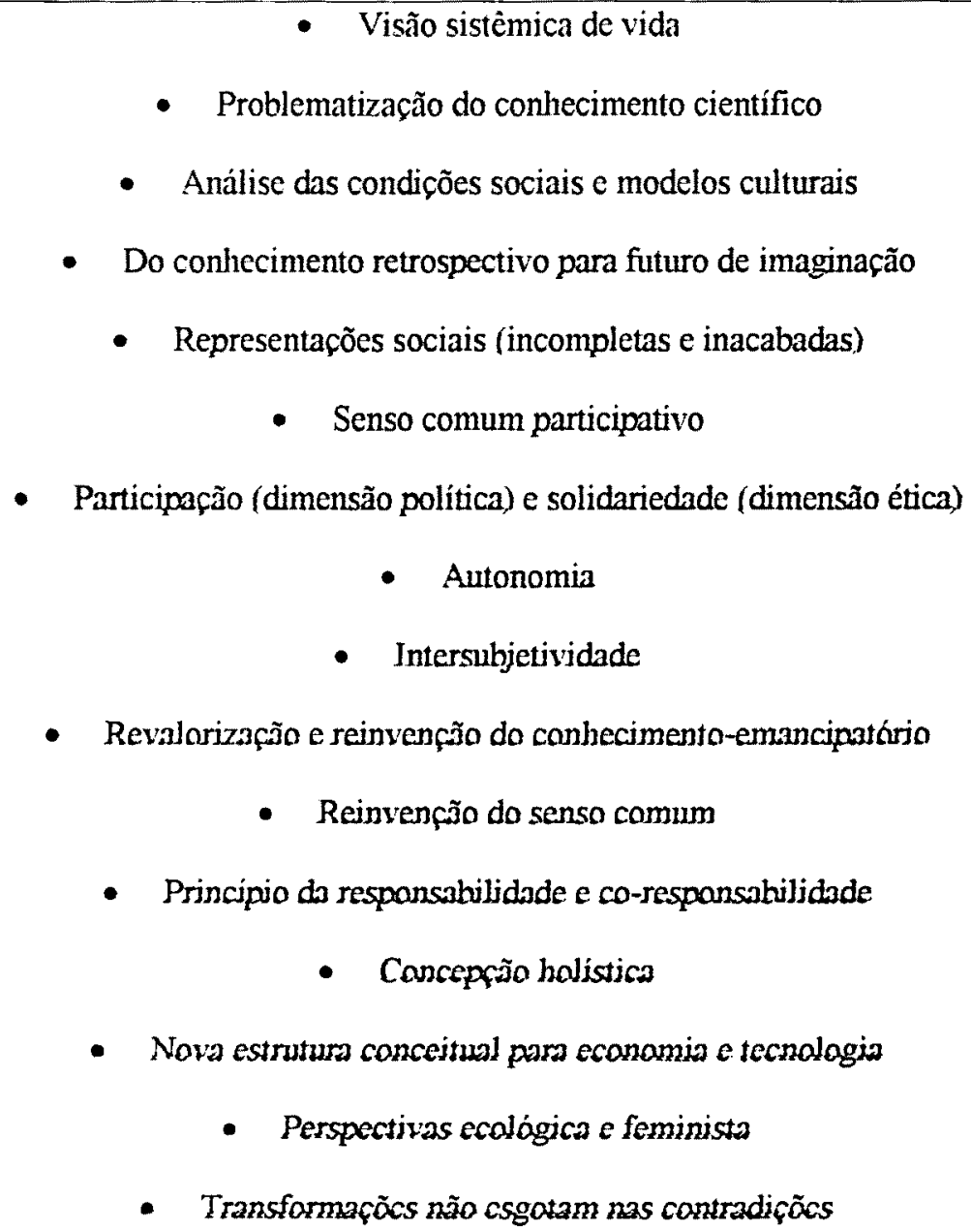 \\
\hline
\end{tabular}

No Brasil, os caminhos da história da Participação tem sido tortuosos, porém, irreversiveis. Foi importante conhecê-los, entendê-los e, de alguma forma, buscar contribuir para sua efetivação. 


\section{2-REFERENCIAL TEÓRICO}

\subsection{Breve Histórico da Participação no Brasil}

Análises de conjunturas de crise tèm mostrado momentos em que grandes questões políticas nacionais mobilizam novos atores, ampliando a participação da sociedade, de modo dinâmico e plural o suficiente para que haja setores sociais organizados e mobilizáveis. Tal ampliação em torno de grandes questões faz com que os personagens de cada momento histórico deixem seus referenciais rotineiros e priorizem as novas questões.

CARVALHO (1998) analisou a participação no Brasil, sob esse ponto de vista, em vários momentos da história dos movimentos sociais. A autora retratou o movimento operário e o camponês, principalmente nos anos entre 1930 e 1960, como os que mais sofreram pressões cooptadoras por parte dos partidos políticos, de parlamentares e governos que buscaram sua participação de forma populista, caracterizada por concessões e pela troca de favores em relações autoritárias, clientelistas, paternalistas e de compadrio.

O regime militar, instaurado em 1964 como citado por RODRIGUES (2002), se constituiu num marco importante na discussão da Democracia e conseqüentemente da Participação. Os movimentos que surgiram para se rebelar contra a ditadura, mediante ruptura da "ordem vigente", do periodo chamado "renascimento da sociedade civil" dos anos 70 , pautaram-se em novas reivindicações e tiveram como resposta a construção da democracia, que culminou com a Constituição Federal de 1988. No entanto, essa luta não se esgotou nesse momento e permanece, até hoje, na medida em que a crise do Estado e o processo de reformas econômicas orientadas para o mercado continuam, por meio da investida da desconstrução das conquistas da Constituição tornando-se então, a divisão real do poder com o povo, o ponto central da instabilidade institucional, agora efetivada não só por meio da sua representação pelo voto, mas também pela intervenção direta e pela participação nos niveis decisórios.

$\mathrm{Na}$ década de 1980, também é importante citar a dinâmica da reforma do setor saúde (o movimento da Reforma Sanitária), quanto à institucionalização dos mecanismos participatórios no Brasil, associada ao impacto da discussão sobre mudanças nas práticas políticas das 
O CONUSAN-SP E OS PARADIGMAS DA PARTICIPAÇÃO

democracias liberais, sobre o sistema de saúde brasileiro, após vinte anos de ditadura militar. A $8^{\mathrm{a}}$ Conferência Nacional de Saúde foi o marco da construção e fortalecimento das propostas de reorientação politica do setor e das medidas sobre a instituição da participação popular nas instàncias públicas garantidas pela Constituição Federal e posteriormente pela Lei Orgânica da Saúde (WENDHAUSEN 2002).

Outros importantes exemplos de momentos conjunturais foram o das "Diretas Já", de 1984, e do impeachment de Collor, de 1992, quando sindicalistas e operários, capitalistas e líderes de entidades empresariais, "direita e esquerda" (conservadores e progressistas) deixaram de operar politicamente a partir da lógica normalmente empregada nas relações entre empresários e trabalhadores; os estudantes deixaram de atuar a partir da lógica própria às questões universitárias, e, mesmo os congressistas deixaram de agir exclusivamente pelas rotinas próprias à correlação de forças parlamentares. E assim passaram a agir em torno da grande questão política nacional colocada na agenda (eleições diretas ou impeachment).

Os antigos donos do poder foram obrigados a discutir a dificil relação entre a participação dos cidadãos mobilizados e a institucionalidade politica, produzida pela Constituição de 1988. Estava posto o conflito entre a mobilização política da sociedade e a mudança da ordem políticoinstitucional.

Dada a rapidez com que fatos como esses acontece, nas conjunturas de crise, toda a estratégia que geralmente empregam se desestrutura. Quando ocorre uma situação de incerteza generalizada entre os diferentes atores, aumenta a dificuldade de cada um em planejar as próprias ações e prever as dos adversários, bem como antecipar os seus possiveis resultados. Sua autonomia de comportamento como classe fica subordinada à relação de poder que se estabelece $\mathrm{e}$ que possibilita, ou não, sua ascensão no plano político.

De acordo com a afirmação de RODRIGUES (2002), nem o Estado nem sua forma de intervenção nos processos econômicos e políticos foram substancialmente alterados até a década de 1990, o que representou uma longa sobrevida do padrão corporativista e autoritário de relação do governo com a sociedade organizada. A Constituição Federal de 1988 estabeleceu o marco da nova ordem política no Brasil, o que refletiu em um processo de transição no qual as dimensões da democratização (liberalização e participação) tiveram um crescimento extremamente desigual. $\mathrm{O}$ aumento da liberalização (do direito à informação e à expressão) foi muito maior do que o da 
O COMUSAN-SP E OS PARADIGMAS DA PARTICIPAÇÃO

participação, ou seja, que a capacidade do povo de influenciar no governo e em suas politicas, fosse por eleições ou por outros meios democráticos.

Sob essa perspectiva, torna-se atual a afirmação de WEFFORT (1992) de que o Brasil vive um sistema dúbio que contrapõe marginalizados e incluidos, sendo que os últimos são os únicos a acessar os mecanismos de participação. Assim, embora a institucionalidade democrática formal faculte a possibilidade de influência, a marginalização de cunho sócio-econômico diminui a capacidade de organização dos grupos sociais, dificultando seu exercício de fato.

Não basta que as mudanças sejam legais, elas também têm de ser estruturais. À medida que um povo tenha assumido, pelas urnas, uma nova opção, como a eleição do Presidente Luiz Inácio Lula da Silva (figura de perfil fora dos padrões do paradigma dominante), há de se vislumbrar "uma luz" para que a participação ocorra em todos os seus aspectos e principios. Espera-se que frutifique em resultados considerados positivos por todos os seus atores.

\section{Participação e Controle Social}

Com a promulgação da Constituição Federal, adotou-se no Brasil uma perspectiva de democracia mista, representativa e participativa, incorporando a participação da comunidade na gestão das políticas públicas por meio do chamado Controle Social. Diversos mecanismos, para esse novo paradigma da participação têm sido implementados. Os Conselhos Setoriais e de Gestão, o Orçamento Participativo e outros instrumentos legais como o plebiscito, a emenda e iniciativa popular têm sido mecanismos encontrados para a efetiva prática do espírito constitucional. No entanto, a participação da sociedade nas funções de planejamento, acompanhamento $\mathrm{e}$ avaliação da efetividade das políticas públicas têm requerido a institucionalização de órgãos deliberativos, representativos da sociedade, de caráter colegiado e permanente. Os Conselhos apareceram então, como espaços institucionais, públicos, de articulação entre governo e sociedade.

O Controle Social foi a conquista da sociedade, na participação do planejamento, acompanhamento e verificação das ações da gestão pública na execução das políticas públicas, avaliando objetivos, processos e resultados, garantida na Constituição Federal (BRASIL 1988) e em leis complementares. No Brasil tem crescido a organização da sociedade civil como resultado 
O COMUSAN-SP E OS PARADIGMAS DA PARTICIPAÇÃO

da busca de soluções dos impasses nas relações entre o Estado e a Sociedade, e ao mesmo tempo também tem aumentado as ações que viabilizam as politicas públicas que têm como objetivo a descentralização do poder de decisão e de recursos na prestação de serviços das áreas sociais, principalmente para setores essenciais como a educação e a saúde, como estabelece a CF - art. 194, VII; art. 198, III; art. 204, II; art. 206, VI, art. 227, parágrafo 7 (BRASIL 1988).

LYRA (2002) abordou um dos aspectos mais importantes para consolidar a democracia, introduzida pela $\mathrm{CF}$, foi a participação direta e pessoal dos cidadãos nos atos de Governo, fundamentado, como visto, no art. $5^{\circ}$, parágrafo único. Antes do processo constituinte, somente o Judiciário admitia, ainda que excepcionalmente, a participação direta do povo, através do Júri Popular, ou mediante a escolha, por entidades representativas de empregadores e empregados, de juizes classistas (CF, art. $11 \S 1^{\circ}$ e 113 ). A partir de 1988, o objeto da ação popular, passou a compreender, não somente a defesa do patrimônio público, mas também a da moralidade administrativa, a do meio ambiente e a do patrimônio cultural. No Legislativo a participação se efetiva por meio da iniciativa popular, o plebiscito e o referendo (CF, art.14, I e II, o art. 49, V, art. 14, III, o art. $61 \S 2^{\circ}$ ). $\mathrm{O}$ autor também destacou que é no âmbito do Poder Executivo que as inovações alcançam maior amplitude e profundidade.

A Constituição Federal contém vários dispositivos que fazem menção expressa à "participação da comunidade" na gestão pública, notadamente na área da saúde (CF, art. 198, III), da seguridade social (CF, art. 194, VIII), da política agrícola, "envolvendo produtores e trabalhadores rurais" no seu planejamento e execução ( $C F$, art. 187, caput), e da assistência social, onde se estabelece, de forma especifica, a participação da população "por meio de organizações representativas" na formulação das políticas e no controle das ações em todos os niveis ( $\mathrm{CF}$, art. 204, II).

Mais um importante exemplo dessas conquistas foi o Estatuto da Criança e do Adolescente, que talvez seja a primeira lei a atribuir à cidadania o exercicio direto da gestão pública. Nesta, aliás, coube com exclusividade, no caso dos Conselhos Tutelares, órgão mais importante previsto no estatuto, conforme art. 132, que "em cada Municipio, haverá, no mínimo um Conselho Tutelar composto de cinco membros, escolhidos pela comunidade local para mandato de três anos, permitida uma recondução". 


\section{O Setor Público e a Participação}

Trazida a discussão para o âmbito do Estado, considerando a legislação e os canais institucionais já mencionados, tendo em vista a concretização da participação para que ações em nivel local se tornem eficazes, afirma-se ser preciso haver descentralização da estrutura organizacional do Estado. Todavia, há necessidade de um novo arranjo institucional-político, facilitador da participação, que ao mesmo tempo considere as experiências e intenções dos movimentos sociais e elimine os vícios hoje presentes na relação entre o Estado e os indivíduos, bem como o clientelismo e a troca de favores esclarecendo a importância da atuação do setor público na viabilização da participação.

JACOBI (1992b) falando sobre as tentativas de promoção da participação pelo governo Luiza Erundina em São Paulo, considerou que, tendo em vista a ampliação do usufruto dos bens pela população, a administração pública teria de estar voltada para a implantação de canais de participação que permitissem um amplo envolvimento dos mais diversos estratos sociais enquanto receptores e emissores da gestão cidadã. Naquele momento a construção desses canais se deu, fundamentalmente e com maior facilidade, nos municipios, devido à proximidade dos indivíduos à gestão pública e ao fato de que os problemas enfrentados cotidianamente serem percebidos primordialmente no nivel local. Contudo, seria preciso que também houvesse nos outros niveis de governo a predisposição democrática e a vontade política de concretizar e apoiar a participação nos Municipios.

\section{Canais Institucionais de Participação}

Diversos mecanismos de participação da sociedade civil na gestão das políticas públicas têm sido implementados no Brasil. Por outro lado, a participação nas funções de planejamento, acompanhamento e avaliação de resultados das políticas públicas requerem a constituição de órgãos colegiados deliberativos, representativos da sociedade, de caráter permanente, além de grande esforço da sociedade em organizar-se nos vários segmentos, a partir de sua própria realidade, baseando-se nos instrumentos legais cabiveis, buscando alternativas que melhorem sua qualidade de vida pela garantia de seus direitos e cumprimento de seus deveres. 
O COMUSAN-SP E OS PARADIGMAS DA PARTICIPAÇÃO

Os Conselhos devem ser espaços públicos de articulação entre o governo e a sociedade. A década de 90 vivenciou uma explosão de criação de conselhos em todo o Brasil. Os Conselhos de Saúde, pela Lei Orgànica da Saúde (Leis Federais de $n^{\circ}$ 8080/90 e 8142/90), tornaram-se obrigatórios em todas as esferas de govemo. Como citado por CORREIA (2000), divulgou-se a existència de 5.201 Conselhos Municipais de Saúde, número próximo ao de Municípios, 5.506 em 1999, nos 27 estados da federação. Essa explosão foi seguida por outros setores sociais. Foram também criados os Conselhos de Educação, igualmente importantes, mas não regulamentados integralmente por lei federal nos estados e municipios, os Conselhos de Escola, os Conselhos de Acompanhamento e Controle Social do Fundo de Manutenção e Desenvolvimento do Ensino Fundamental e de Valorização do Magistério (FUNDEF), os de Assistência Social, os Conselhos Tutelares e de Direitos da Criança e do Adolescente e os Conselhos de Defesa dos Direitos da Pessoa Humana que podem exercer importante papel de formuladores de políticas públicas juntamente com o executivo. Além desses, também foram criados vários outros Conselhos Setoriais em governos democráticos e populares, que igualmente valorizam a participação popular na gestão pública.

Os Conselhos, pelo Brasil afora, tem apresentado características diversas e diferenciadas quanto à natureza, papel, funções, atribuições, composição, estrutura e regimento. No entanto, vale ressaltar que a constituição e efetiva atuação dos conselhos tem possibilitado a participação da sociedade no interior das Unidades Federativas. Cada conselho nacional deve criar os mecanismos de descentralização e instituição das instâncias estaduais e municipais, e os últimos também criarem suas ramificações, seguindo a política do global para o local, de onde deve emanar todo o poder de gestão da vida cotidiana dos cidadãos (BRASIL 1988, art. $1^{\circ}$ ).

\section{Condicionantes para participação institucional}

Devem ser lembrados os condicionantes para a participação, citados por TOURAINE (1992). É no nível institucional politico que se dá a tradução da orientação do sistema de ação histórica e da estrutura de classes para os diversos niveis de organização da sociedade. As estruturas institucionais são, portanto, fundamentais por formalizarem as instâncias de decisão que podem transformar as intenções de cidadãos e governos em objetivos executáveis e, portanto, 
em ą̧ões concretas. É óbvio que as atenções não devem se voltar somente para os aspectos formais, mas sem eles, há o risco de as demandas permanecerem num espaço inexistente, vazio, e por isso de dificil realização no sistema democrático.

JACOBI (1992b) considerou um grande desafio à construção de uma engenharia institucional que de conta, simultaneamente, de garantir um discurso de transparência administrativa, equacionar as demandas sociais e implementar formas de participação adequadas ao paradigma emergente. Mais concretamente, a necessidade seria de que as expectativas da população não fossem frustradas, impedindo a queda da sua motivação, além de que se prevenisse a manipulação política através da transparência da prática, não só do discurso.

MENDES (1996) desenvolveu uma análise, em seu estudo sobre orçamento participativo, a respeito dos diferentes aspectos da participação no nivel municipal, adiante descrito.

- A composição dos órgãos de participação: o peso dos representantes deve garantir a eqüidade de representação dos grupos sociais e também dos membros pertencentes à administração pública. $\mathrm{O}$ autor destacou a importância de perceber quais os grupos que conseguem ser representados, que podem demandar a manutenção do atendimento aos interesses dos detentores do poder ou podem passar a incluir os interesses dos grupos desfavorecidos, e por isso, mais necessitados. Na questão específica do planejamento orçamentário, a Constituição Federal abriu espaço somente para as entidades legalmente constituidas, o que reforça o quão fundamental é a organização e institucionalização dos grupos. Mendes questionou sobre o que oferecer aos grupos que não puderam ainda se estruturar, formados por aqueles que mal têm condições mínimas de sobrevivência, dadas às imposições legais que os excluem do processo. Demonstra um outro desafio, então, tornar a sociedade mais permeável à inclusão dos grupos marginalizados, possibilitando a incorporação de novos valores aos organismos;

- As mediações de interesses: o fator diz respeito à forma de representação e de participação nas decisões, se por eleições ou por representação direta. O número de pessoas é uma variável que pode inviabilizar a ocorrência de eleições e a forma direta e independente de participação como meio para tomada de todas as decisões. A escolha pela representação, sistema que em princípio traz maior eficiência na tomada 
O COMUSAN-SP E OS PARADIGMAS DA PARTICIPAÇÃO

de decisões, pode criar problemas de legitimidade, se os representantes eleitos passarem a defender seus próprios interesses em detrimento dos da comunidade. Coloca como outro ponto importante a ingerência que o poder público comete nas instâncias definidas, já que é possivel neutralizar as influências dos grupos sociais, por meio da indicação dos componentes que devam participar das decisões. De acordo com MENDES (1996), a mentalidade de que a participação é tida como uma dádiva do Estado e não como um direito do cidadão ainda predomina, a possibilidade de manipulação pela administração pública na constituição dos órgãos tem sido grande. A presença no setor público daqueles realmente comprometidos com o ideal da participação é então necessária para que a mesma aconteça. Portanto, deve haver esforços para tornar as decisões da administração pública mais ágeis, buscando o real (e dificil, por diversos motivos históricos) comprometimento dos servidores públicos, rompendo os vícios do aparelho do Estado;

- A representatividade dos diversos interesses: quanto mais heterogênea a composição dos órgãos de participação, tanto mais representativa a mesma se torna, embora, devido à diversidade, possam surgir conflitos que paralisem as suas ações, bem como possa ser dificultada a pressão objetiva, passivel de atendimento, sobre a administração. Se for percebida uma homogeneidade nos interesses presentes, o risco, como afirmou MENDES (1996) é o da "privatização do serviço em benefício de uma categoria limitada de cidadãos".

Na análise realizada por MENDES (1996) apareceram, bem determinadas, as condições que devem regular a participação no âmbito institucional, sistematizadas a seguir.

Condicionantes para Participação, que devem ser garantidos pelo Nível Institucional (MENDES, 1996)

- Transparência administrativa

- Equacionamento das demandas sociais

- Garantia de forma de participação 
O COMUSAN-SP E OS PARADIGMAS DA PARTICIPAÇÃO

- Motivação da participação

- "Eqüidade" de representação dos grupos sociais

- Espaço para defesa de interesses das entidades

- Acesso ao planejamento orçamentário

- Inclusão de grupos marginalizados

- Forma de representação de participação (eleições)

- $\mathrm{N}^{\circ}$ participantes (definição)

- Tomada de decisão (meio)

- Não ingerência e interferências na instância

- Execução e concretização das propostas

- Agilidade e comprometimento do governo

- Administração de conflitos

Essa referência serve de parâmetro para analisarmos qualquer tipo de canal institucional de participação e avaliarmos se sua composição garante eqüidade de representação, se media interesses a ponto de buscar consensos e se a representatividade é legítima, não comprometendo os interesses das bases.

\section{Participação no Nível Local}

$\mathrm{O}$ atendimento às demandas sociais, a resposta fundamental que o Estado realmente democrático deve oferecer para o seu povo, encontrará na participação conjugada às políticas de descentralização, a possibilidade de interação constante entre os atores do processo, tendo em vista a definição das prioridades da sociedade. $O$ surgimento de interlocutores organizados em instituições com presenças locais, que representem a coletividade de forma autônoma em relação ao governo (sem dependência administrativa e financeira), assim como a sua valorização pelo setor público quando da formulação e execução de políticas, é fundamental para a viabilização da participação popular. Na outra ponta, os ocupantes de cargos da administração pública devem ser favoráveis à idéia de participação, vencendo os obstáculos de tornar concreto o discurso político.

Em conformidade com esse novo paradigma para gestão municipal, SANTOS JR (2001) estudou novas formas de governar localmente. Ele denominou governança o poder de governar 
além dos focos de eficiência e condições do bom exercício: governar para as transformações nas instituições de governo local, de modo a captar as emergências das novas formas de governo, que articulem diversos processos políticos e administrativos. CALDERÓN (2000) fez um estudo detalhado dessa perspectiva político-administrativa na cidade de São Paulo e todo o processo de discussão no qual se envolveram desde as entidades mais representativas da cidade até as mais simples, dos bairros mais pobres e excluidos da "infra-estrutura", mostrando os desrespeitos à Lei Orgânica do Município (SÃO PAULO 1990) quanto às alterações para a nova forma de gestão participativa.

Partindo das observações de CALDERÓN (2000) de que a concretização da participação se dá preferencialmente no nivel municipal, é interessante definir os tipos básicos possiveis de participação nessa instância, assim como indicar alguns requisitos básicos que devem ser notados pelos agentes (públicos ou representantes da sociedade civil) que pretendam estimular real participação popular.

JACOBI (1992b) citou duas modalidades gerais de participação nas prefeituras. A participação setorial, para temas específicos (responsabilidade das Secretarias) e a participação territorial, através da descentralização de competências.

A primeira modalidade objetiva a integração dos grupos sociais de base aos organismos do Estado, utilizando-se para isso dos mecanismos de participação apropriados. Diferenciem-se esses mecanismos dos da democracia representativa já estabelecida, como o voto, para que os mesmos possam ser captados e entendidos diferentemente pela população. Esta modalidade se concretizou, por exemplo, nas propostas de orçamento participativo, servindo de mecanismos as reuniões dos diversos grupos sociais. Estas geraram resultados, os quais foram discutidos entre os representantes dos diversos grupos, os da própria administração municipal, como Secretarias de Planejamento e das Câmaras de Vereadores, saindo desse processo as decisões relativas a esse assunto em particular. Ou seja, a competência não foi descentralizada para instâncias mais restritas, embora a estas fossem dadas as oportunidades de definir previamente suas prioridades.

$\mathrm{Na}$ segunda modalidade, o mecanismo está dentro do Estado, que se descentraliza, delegando competência a niveis mais restritos, tão próximos da base que se pode confundir com as organizações de base locais. Essa descentralização de poder permite ações e respostas vindas 
diretamente dos grupos sociais, e sua aplicação tem sentido principalmente em municípios grandes ou bastante distribuídos geograficamente, como foi o caso de São Paulo, estudado por JACOBI (1992b).

O mesmo autor também laçou très objetivos para a participação enquanto processo de democratização municipal: a) promover a iniciativa a partir de programas especiais visando o desenvolvimento de objetivos de interesse coletivo; b) reforçar a sociedade organizada e ampliar sua capacidade técnica e administrativa, tornando as entidades competitivas; c) desenvolver a capacidade de participação na definição de programas e projetos na gestão dos serviços públicos municipais.

Temos de considerar que o Estado, além de favorecer as possiveis aberturas para a participação da sociedade, tem de ser capaz de administrar possiveis conflitos advindos desse processo.

\section{Atual Modelo de Gestão Municipal}

Os modelos brasileiros de gestão em curso, que em grande parte ainda respondem aos antigos paradigmas, ou como diria SANTOS BS (2000) paradigmas dominantes, centralizam poder e procuram manter a hegemonia do capitalismo. Mas, a transição para novos tempos, os do paradigma emergente, é inevitável e já está acontecendo nos governos locais de gestão democrático-popular.

O novo paradigma de gestão municipal, tendência mundial para gestão local, é estar trabalhando com a comunidade, oferecendo formas e dispositivos de convergência para a formação de uma sociedade auto-sustentável, que viabilize condições para a inclusão social, autoestima, consciência do papel de ator social e sujeito formador e estimulador de políticas públicas. O municipio deve promover espaços deliberativos e construir redes de parcerias com a sociedade civil organizada, fortalecendo as interfaces das Políticas Públicas com as Políticas de Governo.

Com base no referencial exposto, seguem relacionados os principios que devem ser adotados pelos serviços públicos diretamente em contato com os cidadãos, de acordo com esse novo paradigma:

a) universalização, eqüidade e qualidade; 
O COMUSAN-SP E OS PARADIGMAS DA PARTICIPAÇÃO

b) descentralização das políticas públicas;

c) gestão democrática e participativa;

d) formas de controle: interno, externo, controle social;

e) mecanismos de controle social: conselhos e outras formas de organização (como os gerentes sociais);

f) formação de Conselhos, como todos os mencionados e todos os outros que possam ser criados, no setor público e complementar.

\section{Cidade de São Paulo}

O Municipio de São Paulo com extensão territorial de $1.493 \mathrm{Km}$ (Enciclopédia Folha Ilustrada 1999,) na região metropolitana, tem perto de 11 milhões de habitantes (IBGE 2001). Capital do Estado mais populoso, do maior parque industrial e da maior produção econômica do pais, é uma das cidades mais importantes da América Latina e quarta mais populosa do mundo.

Nos últimos anos o Estado tem tido menor crescimento econômico que os de outras regiões, mas, ainda, continua sendo alvo de grandes investidores. A Capital tem tido proporcional participação nesse movimento, contudo, mudando seu perfil setorial para serviços, tendência crescente.

Tem bom mercado consumidor, de maior poder aquisitivo do Mercosul, e infra-estrutura urbana central, que facilita a vazão da massa produtiva.

A maior cidade da América do Sul é responsável por 15\% do PIB nacional, mas, apesar de toda essa grandeza econômica, grande parte da população, especialmente a periférica, vive em condições de extrema pobreza. A infra-estrutura urbana nesse espaço é insuficiente para atender às necessidades básicas de transporte, saúde, educação, moradia e outras de suma importância, como emprego, com déficit cada vez maior, acompanhado por miséria e violência (LEAL 1999b).

Mesmo a LOM (SÃO PAILO 1990) garantindo mudanças para administrar esse imenso território, com perspectivas e nuances locais, sucessivas gestões não alteraram sua estrutura. 
O COMUSAN-SP E OS PARADIGMAS DA PARTICIPAÇÃO

Atualmente passa por intenso trabalho de reformas estruturais: administrativas, políticas e sociais. O mais importante exemplo é a descentralização da gestão para as Subprefeituras. Começou pela transição, pelos chamados Governos-Locais, para repensar a nova estrutura a partir da realidade enquanto era apreciada a matéria pela Câmara Municipal.

\section{Subprefeituras}

A Lei que criou as subprefeituras (Lei $n^{\circ} 13.399$ de 01.08.02) demandou inúmeras regulamentações e cumprimento de prazos para sua total implantação. O Decreto $\mathrm{n}^{\circ} 42.325$ de 22.08.02 definiu as divisões administrativas (as Subprefeituras são 31) e criou as unidades orçamentárias.

A Lei tem objetivos estratégicos:

$\Rightarrow$ Que atuem como indutoras de desenvolvimento local, transformando aglomerados humanos regionais em cidades, exercendo no nível local o papel de articulador dos interesses da população; que formulem e implementem políticas capazes de criar e reforçar as vocações de desenvolvimento local;

$\Rightarrow$ Que amplie oferta, agilize e melhore a qualidade dos serviços locais;

$\Rightarrow$ Que facilite o acesso a possibilitar transparência aos serviços públicos, tornando-os mais próximos dos cidadãos;

$\Rightarrow$ Que institua mecanismos que democratizem o poder público, criando canais efetivos de participação popular (o que está acontecendo: conselhos, orçamento participativo, fóruns de discussão temática...).

$\Rightarrow$ Que exerça o papel de "Prefeitura Local", com coordenadorias de serviços, agrupando-os em áreas, otimizando recursos e agilizando resultados.

Em linhas gerais as principais atribuições das Subprefeituras são:

$\Rightarrow$ Gestão de todos os equipamentos públicos municipais localizados no seu âmbito de gestão;

$\Rightarrow$ Planejamento, execução e controle de todas as políticas públicas desenvolvidas no território; realização de serviços e obras de sua competência; 
$\Rightarrow$ Elaboração, implantação e monitoramento do Plano Diretor Regional em sintonia com o Plano Diretor da Cidade;

$\Rightarrow$ Controle e uso do solo e do meio ambiente unificando ações fiscais, antes dispersas em várias secretarias com dificuldades de atuação no imenso território do municipio;

$\Rightarrow$ Autonomia de execução orçamentária e realização de licitação, contratação e gerenciamento de contratos;

$\Rightarrow$ Administração de pessoal com atribuição de execução de concursos, nomeações e outras ações pertinentes;

$\Rightarrow$ Porta única de fiscalização do território;

$\Rightarrow$ Manutenção e atualização de cadastro local das áreas públicas e agregação das ações que estão sendo descentralizadas.

Segundo FALCÃO (2003), a implantação das subprefeituras foi a mais radical experiência de descentralização de poder já vista no Brasil, tornando ainda mais efetivas a fiscalização e a colaboração dos munícipes quanto aos atos dos administradores.

Para esse contexto a Participação Popular não acaba no voto. A Prefeitura do Município de São Paulo (PMSP) colocou em funcionamento em 2001, na Secretaria de Governo, a Coordenadoria de Participação Popular (CPP) para elaborar a política de participação na cidade de São Paulo, fazer um apanhado dos conselhos já criados, promover articulação entre os mesmos e assessorar os Conselhos Municipais já instituídos ou que venham a ser criados, garantindo assim, a existência de canais institucionais de participação, com condições de funcionamento (CPP, 2003).

"[...] Sabedores dos vários e grandes entraves que dificultam as ações de forma organizada e coordenada entre os vários conselhos, propomos estabelecer um diálogo $e$ troca de experiências, de forma permanente, entre os vários conselhos da cidade, no intuito de propiciar ofortalecimento da cidadania e da democracia [....]" (CPP 2003)

Além da CPP, também existem as Coordenadorias de Assuntos da População Negra, Mulher, Juventude e Orçamento Participativo, que para definir o orçamento de 2003 contou com a participação de 55 mil munícipes votantes (FALCÃO 2003). 
De acordo com a CPP (2003), foi realizado em novembro de 2002 o I Encontro de Conselhos da Cidade de São Paulo, com a presença de 13 Conselhos Municipais e vários representantes do legislativo e executivo municipal. Segundo ela, esse encontro apontou eixos de atuação para os anos de 2003 e 2004 como o Ciclo de Formação de Conselheiros, realização do II Encontro, constituição de um Fórum Interconselhos e a criação de canais e instrumentos de comunicação.

[Desses eixos apontados no I Encontro de Conselhos, quase todos já foram implementados, só falta a efetivação da criação de canais e instrumentos de comunicação. O primeiro passo foi o Informativo produzido por uma comissão que integra dois representantes de cada conselho constituido e a CPP.]

Os conselhos que integraram o Fórum Interconselhos, no primeiro momento, foram:

Conselho Municipal de Políticas Públicas de Drogas e Álcool

Conselhos Gestores dos Parques Municipais

Conselho Municipal do Meio Ambiente e Desenvolvimento Sustentável

Conselho Municipal da Pessoa Deficiente

Conselho Municipal dos Direitos da Criança e do Adolescente (com Conselhos Tutelares)

Conselho Municipal de Educação de São Paulo

Grande Conselho Municipal do Idoso

Conselho Municipal de Saúde (com Conselhos Distritais e Gestores de Unidades)

Conselho Municipal de Habitação

Conselho Municipal de Assistência Social

Conselho Municipal de Trânsito e Transporte

Conselho do Orçamento Participativo

Conselho Municipal de Segurança Alimentar e Nutricional de São Paulo

Também participa do Fórum, atualmente, o Conselho Municipal da Cultura. 


\subsection{PARTICIPAÇÃO NO CONTEXTO DA SAÚDE}

ROZENFELD e COSTA (2000), resgataram as origens da busca da saúde na história das civilizações. Segundo as autoras, povos antigos, como babilônios e hindus, estabeleceram preceitos morais e religiosos, fixados nos códigos de Hamurabi e de Ur-namu, e regras de conduta dos profissionais que tratavam das doenças. Tinham a saúde como essência da dignidade humana. Desde a antiguidade clássica até a Idade Média se desenvolveram ações de saneamento do meio ambiente, normatização de práticas profissionais, cuidados com medicamentos, as boticas, os alimentos. A solução desses problemas cabia à administração das cidades, do poder público. A partir do Estado Moderno, a ordem econômica ditava as regras de conduta, a saúde do povo seria cuidada e controlada para aumentar o poder e a riqueza das nações. As revoluções do século XVIII e os novos conceitos de controle político-científico do século XIX deram outro sentido à saúde pública. A ampliação de legislação e o fomento de mobilização popular foram as marcas do século $\mathrm{XX}$, molas propulsoras para reformulações de normas reguladoras do mercado. $\mathrm{A}$ constituição da Organização Mundial de Saúde, após a Segunda Guerra Mundial, proclamando saúde como um direito humano, foi o principal ganho internacional.

Segundo MENDES (1999), os países de primeiro mundo na primeira metade da década de 1970 começaram a ser fortemente questionados com base em novas concepções do processo saúde-doença que procuram articular dimensões de saúde com condições de vida.

A partir daí a Conferência de Alma-Ata, Conferência Internacional Sobre Cuidados Primários de Saúde, em seu capitulo I, reafirmou enfaticamente que a saúde - estado de completo bem-estar físico, mental e social, e não simplesmente a ausência de doença ou enfermidade - é um direito humano fundamental, e que a consecução do mais alto nível possivel de saúde é a mais importante meta social mundial, cuja realização requer a ação de muitos outros setores sociais e econômicos, além do setor saúde. Enunciou no bojo de suas considerações que é necessária a participação dos povos no planejamento e na execução de seus cuidados com saúde" (MS 2000).

Essa Conferência deu origem a um grupo de estudo que em 1985 chegou a conclusões em documento oficial que apontaram para a realização da $1^{a}$ Conferência Internacional de Promoção 
da Saúde, que aconteceu em Ottawa/Canadá. PELICIONI (2000) enfatizou que a Carta de Otawa considerou a Promoção da Saúde um novo paradigma mundial para a saúde pública e assim, um processo de fortalecimento e capacitação de indivíduos e coletividade no sentido de ampliar suas possibilidades de controlar os determinantes de saúde e doença e a obtenção de melhores níveis de saúde. Outras conferências (em Adelaide, na Austrália; Sundsvall, na Suécia; Bogotá, na Colômbia e Jacarta, na Indonésia), tiveram em comum a idéia de que é necessário preparar (amplo processo de capacitação para dar condições plenas) as populações para se organizarem, participarem localmente de todas as instâncias de planejamento, decisão e controle sobre os rumos de sua saúde, de sua vida.

No contexto das relações sociais, a participação social se definiu em propósitos e atividades tão variados como atribuir responsabilidades sociais de uns atores a outros, votar em eleições, fazer parte de movimentos sociais, desenvolver estratégias para conseguir que gente colabore com programas e projetos, quaisquer ações de organizações sociais para reivindicar suas necessidades e realizar seus interesses, dentre outras.

"Concepções reducionistas geralmente limitam a compreensão de partes ou pequenas dimensões da participação social (comunidades, grupos, pessoas), com caracteristicas determinadas (urbano-marginalizadas, mulheres, adolescentes, etc.) e não frente $\grave{a}$ totalidade dos processos sociais. Cada setor tende a impulsionar formas de participação social, ignorando as condições sociais, culturais, politicas e econômicas que a determinam, reduzindo geralmente, às atividades participativas com fim de obter êxito em seus programas setoriais em detrimento do contexto dos processos sociais da realidade".(OPAS 1993)

Foi muito importante a afirmação feita pela OPAS (1993) sobre essa temática, quando se referiu aos espaços e cenários como instâncias de convergência, encontro e relação entre os atores sociais, estabelecidos e reconhecidos com o fim de permitir a solução de conflitos. Estes cenários não seriam necessariamente espaços fisicos, e sim âmbitos de encontro socialmente assumidos como legitimos para a função social a que se destinam. Podem ser instituições comunitárias, formais ou informais, públicas ou privadas, locais, nacionais, internacionais, todas teriam 
OCOMUSAN-SP E OS PARADIGMAS DA PARTICIPAÇÀO

condições de fazer parte da transição paradigmática e proporcionar aos cidadãos, dentro de seus limites, a autonomia, o conhecimento-emancipatório, o poder de decisão.

No Brasil, podem ser citadas como instâncias de participação no setor saúde as inúmeras Conferências Nacionais, Estaduais e Municipais que ocorreram até o momento. Além dos Conselhos de Saúde, em todos os niveis, seus avanços e os fóruns populares, que pelo país afora debatem o tema.

O Conselho Municipal de Saúde, uma de nossas referências para observar as formas de participação institucionais, nasceu de uma Plenária de Entidades, em junho de 1989 (Portaria SMS n'1166, de 29/06/89), mesmo antes de promulgada a Lei Orgânica Municipal, em 1990 e as Leis Orgânicas Federais (8080/90 e 8142/90) que instituiram o Conselho Nacional de Saúde. (CPP 2003)

As Leis Orgânicas da Saúde citadas (8080/90 e 8142/90) deram origem às Normas Operacionais Básicas (NOB) como forma de operacionalizar sua aplicação, detalhando todos os campos do setor saúde, ratificando seu cumprimento e enfatizando a necessidade da participação da sociedade, no caso da saúde, como obrigatoriedade para repasse de verbas (CARVALHO et al 1993 e LEVCOVITZ et al 2001). O campo da Alimentação e Nutrição é citado nas NOB como parte do detalhamento dos campos a terem atenção integral.

\section{Conselho Municipal de Segurança Alimentar e Nutricional de São Paulo COMUSAN - SP}

O desdobramento do processo de discussão das políticas de saúde serviu também como estratégia no combate à Fome e à miséria.

A construção da proposta de política de Segurança Alimentar para o pais teve expressão na década de 90, por volta de julho de 1994, quando se realizou a I Conferência Nacional de Segurança Alimentar (CONSEA), em Brasilia. Embora, tenha-se registro da realização do Seminário "FOME - o Desafio Dos Anos 90", realizado pela Secretaria Municipal de Abastecimento (SEMAB) no periodo de 16 a 19 de outubro de 1990, que objetivou discutir as politicas do setor, com base e apoio das propostas da FAO - Organização das Nações Unidas para 
O COMUSAN-SP E OS PARADIGMAS DA PARTICIPAÇÃO

Agricultura e Alimentação. O termo de referência para a elaboração do seminário foi "A Problemática do Abastecimento e da Alimentação nas Áreas de Baixa Renda dos Grandes Centros Urbanos". O referido seminário culminou com uma carta a todos os níveis de governo, intitulada "Carta da Fome", e o "Manifesto ao Povo Brasileiro", dirigido à nação, clamando pelo fim da Fome. Embora o Seminário tenha tido apoio da FAO e tenha sido de suma importância, terminada a gestão do Governo que o promoveu, nada mais se falou.

Os resultados daquela I Conferência Nacional de Segurança Alimentar (1994) consolidaram dois aspectos básicos. O primeiro, de que o processo de desenvolvimento sócioeconômico do Brasil necessitava garantir, obrigatoriamente, a segurança alimentar e nutricional para todos. O segundo aspecto foi a comprovação, na prática, da exigência de uma articulação entre sociedade civil e governo para avançar na busca das condições de segurança alimentar, respeitados os diferentes papéis inerentes a cada parceiro, fosse ele público ou privado.

Nos últimos anos houve uma grande desmobilização dos setores organizados da sociedade civil com o Poder Público, com o encerramento das atividades do CONSEA (Conselho Nacional de Segurança Alimentar), pouco após sua criação (1993) e da transferência de parte de suas atribuições para o "Comunidade Solidária", programa ligado à Presidência da República. Depois desse fato sobressairam-se alguns comitês do Movimento pela Ética na Política e a Ação da Cidadania Contra a Miséria e pela Vida, por influência do sociólogo Herbert de Souza (Betinho), que tentaram ampliar a discussão de ações como a emergência da reforma agrária e a reorientação das políticas de abastecimento alimentar (CASTRO 2003).

Eventos internacionais como a Cúpula Mundial de Alimentação, realizada em Roma, em novembro de 1996 (FAO 1996), ocorreram. Nessa, foi sistematizada uma definição para segurança alimentar, onde foram incorporadas outras questões, como segue:

"SEGURANÇA ALIMENTAR E NUTRICIONAL é a garantia do direito de todos ao acesso a alimentos de qualidade, em quantidade suficiente e de modo permanente, com base em práticas alimentares saudáveis $e$ sem comprometer o acesso a outras necessidades essenciais e nem o sistema alimentar futuro, devendo se realizar em bases sustentáveis. Todo país deve ser soberano para assegurar sua segurança alimentar, respeitando as características culturais de cada povo, manifestadas no ato de se alimentar. É responsabilidade dos Estados Nacionais assegurarem este direito e devem 
O COMUSAN-SP E OS PARADIGMAS DA PARTICIPAÇÃO

fazêe-lo em obrigatória articulação com a sociedade civil, cada parte cumprindo suas atribuições especificas" (FAO 1996).

No município de São Paulo, a retomada das ações na área de Segurança Alimentar ocorreu com a iniciativa da Secretaria Municipal de Abastecimento, através do Departamento de Inspeção Municipal de Alimentos (SEMAB/DIMA), de interagir com os diversos setores da sociedade civil, de acordo com o estabelecido em Plano de Governo e Plano Diretor da cidade (Secretaria Municipal de Planejamento Urbano 2002). No decorrer de 2001, tal iniciativa culminou com a I CONFERÊNCIA MUNICIPAL DE SEGURANÇA ALIMENTAR E NUTRICIONAL DE SÃO PAULO, realizada de 07 a 09 de dezembro do mesmo ano (COMUSAN-SP, 2002). A preparação para esse evento começou em maio de 2001, num Fórum sobre Segurança Alimentar e Nutricional (DOM 10/05/01), que discutiu a criação do Conselho. Constituiu-se no mesmo Fórum uma Comissão Provisória (formada por representantes das instituições presentes) que desde então organizou a realização da I Conferência e a eleição dos membros da $1^{2}$ gestão do COMUSAN-SP. A escolha de delegados para participar da Conferência deu-se por segmento, em nove plenárias (DOM 17/08/01 e 01/11/01), num total de 360 participantes.

O COMUSAN-SP foi criado na I Conferência Municipal de Segurança Alimentar e Nutricional de São Paulo, com base na Constituição Federal de 1988, na Lei Orgânica Municipal de 1990, na Lei Orgânica da Saúde - 8080/90 (e 8142/90), no Código Sanitário do Estado de São Paulo de 1998 e em referências sobre segurança alimentar, como o "Tratado das ONGs de Segurança Alimentar", Rio 92 (FIONG 1992), em anexo 04, criação de Conselhos de Saúde e Conselhos Estaduais de Segurança Alimentar, existentes até então.

A I Conferência aconteceu nos dias 07, 08 e 09 de dezembro de 2001. A Secretaria Municipal de Abastecimento (SEMAB) da Prefeitura do Município de São Paulo (PMSP) e várias entidades da sociedade civil organizada reuniram-se com o objetivo de promover um espaço aberto para todos os segmentos debaterem, analisarem e avaliarem a situação de segurança alimentar e nutricional no município de São Paulo, além de prepararem propostas e de elegerem membros titulares e suplentes do COMUSAN-SP.

$O$ direito de toda a população ao acesso a uma alimentação saudável segura e adequada foi a preocupação dos representantes do poder público, entidades patronais, entidades sindicais, instituições de ensino e organizações não governamentais presentes na Conferência. 
O COMUSAN-SP E OS PARADIGMAS DA PARTICIPAÇÃO

A posse do Conselho ocorreu logo após a eleisãa, na Plenária Final da I Conferência em 09/12701.

Então, a partir da I Conferência, foi constituído o Conselho Municipal de Segurança Alimentar e Nutricional de São Paulo (COMUSAN - SP), com a indicativa de ser formalizado, através de Decreto ou Lei, pela Prefeita de São Paulo, com homologação e publicação em Diário Oficial do Município.

O COMUSAN-SP, embora de caráter consultivo, tem por finalidade atuar na formulação e controle da execução da politica municipal de segurança alimentar e nutricional, nas estratégias e na promoção do processo em toda a sua amplitude, no âmbito dos setores público e privado.

O COMUSAN-SP encontra-se constituído por 40 membros titulares e igual número de suplentes, com mandato de 24 meses, tendo direito à recondução (Decreto ${ }^{\circ} 42.862 / 03$, em anexo).

Suas composição e características serão detalhadas pela pesquisa.

Por ser o primeiro Conselho Municipal do gênero no Brasil o COMUSAN-SP chamou a atenção de vários municípios, que interessados em implantar o Programa Federal "Fome Zero" queriam antes disso ter um Conselho de Segurança Alimentar que pudesse geri-lo. 
O COMUSAN-SP E OS PARADIGMAS DA PARTICIPAÇÃO

\section{3 - OBJETIVOS}

\section{Objetivo Geral}

Foi identificar como se deu a participação dos membros do Conselho Municipal de Segurança Alimentar e Nutricional de São Paulo e quais suas perspectivas, na gestão 2001-2003.

\section{Objetivos Especificos}

Pretendeu-se conhecer:

- Como se deu a representação dos segmentos no COMUSAN-SP;

- Que trabalhos foram desenvolvidos (percepção e inferências) e

- Como se deu a interação (relacionamento) entre os participantes dos segmentos.

- Outros canais institucionais de participação social que os membros do conselho utilizaram. 


\section{4-METODOLOGIA}

\section{Metodologia Participativa}

"Trata-se de permitir uma visão critica da sociedade, a compreensão da natureza dialética das relações sociais e a conviç̧ão de que é possivel transformá-las". (Paulo Freire)

"Se quereis profetizar os futuros, consultai as entranhas dos homens sacrificados: consultem-se as entranhas dos que se sacrificaram e dos que se sacrificam; e o que elas disseram, isso se tenha por profecia". (Antonio Vieira)

A Metodologia Participativa pressupõe a construção coletiva do conhecimento e a intervenção conjunta no processo de desenvolvimento de um dado projeto. Para tanto, imprescindivel que se considere toda e qualquer aresta do objeto em estudo. As pessoas, mesmo que representem entidades, são únicas no conhecimento e na ação e assumem-se partes do coletivo se incorporarem a idéia de plena participação. A produção cultural de uma comunidade tem como uma de suas características a resistência a conceitos, conhecimentos e atividades que ameacem destruir sua identidade. Por isso, não é possivel fazer uso de um único modelo (método), mas sim de um caminho que ofereça várias possibilidades (métodos) de respeitar $e$ atender às diferenças.

A metodologia proposta mesclou métodos já conhecidos e os adaptou para alcançar a amplitude dos atuais paradigmas da participação no COMUSAN-SP. 
OCOMUSAN-SP E OS PARADIGMAS DA PARTICIPACÃO

\subsection{Metodologia Qualitativa}

MINAYO (1994), demonstrou que a pesquisa qualitativa responde a questões muito particulares, trabalha com o universo dos significados, motivos, aspirações, crenças, valores e atitudes, corresponde a espaços mais profundos das ações e relações humanas.

Numa linguagem dialética, a metodologia qualitativa possibilitou construir o modo de conhecimento-emancipatório que SANTOS BS (2000) tratou. As representações sociais, suas vivências, possibilitaram compreender as estruturas e instituições como resultado das ações e relações sociais, parte de um todo, muito maior que seu nivel local.

Os conceitos, linguagem, proposições, métodos e técnicas foram construidos num ritmo, próprio e particular, que implicou em processo de participação na realização da pesquisa. A pesquisa exploratória foi de fundamental importância na elucidação dos caminhos

No desenvolvimento dessa metodologia de pesquisa foram percorridos os seguintes passos: pesquisa exploratória, revisão bibliográfica, pesquisa documental, pesquisa descritiva somada à pesquisa com entrevistas. Foi necessário também demonstrar os instrumentos para tais passos.

\section{Fase Exploratória da Pesquisa}

Para preliminarmente interrogar o objeto de pesquisa e obter bases de inferência sobre os dados coletados no COMUSAN-SP, procedendo posteriormente à análise de conteúdo (MINAYO 1994), foi realizada pesquisa exploratória com os resultados do trabalho dos grupos do "I Fórum de Democracia Participativa", ocorrido em 04 e 05 de julho de 2002 (conforme anexo 01), para produzir categorização prévia e também auxiliar no reagrupamento das categorias após exame dos mesmos. 
O COMUSAN-SP E OS PARADIGMAS DA PARTICIPAÇÃO

\section{Revisão Bibliográfica}

Através de levantamento bibliográfico buscou-se conhecer trabalhos de autores que discutiram os paradigmas sociais e suas relações com a participação e o controle social em conselhos de saúde, bem como a legislação pertinente.

\section{Pesquisa Documental}

Foi realizada a revisão dos seguintes documentos do COMUSAN-SP:

- Atas de reuniões (DOM 2001 a 2003 e COMUSAN-SP 2002, 2003);

- Relatórios técnicos, de trabalhos da equipe de apoio (SEMAB 2001, 2002, 2003);

- Resoluções da I Conferência Municipal de Segurança Alimentar e Nutricional de São Paulo; realizada em dezembro de 2001 e documentos preliminares da II Conferência Municipal de Segurança Alimentar e Nutricional de São Paulo (SEMAB 2001, COMUSAN-SP 2002, 2003);

- Documentos e registros das entidades, encaminhados ao COMUSAN-SP (COMUSAN-SP $2002,2003)$.

\section{Pesquisa Descritiva}

A partir da pesquisa exploratória verificou-se como poderia ser a participação dos atores.

O impulso do movimento gerado pelas experiências participativas citadas foi uma das melhores oportunidades e vantagens que ofereceram as estratégias de organização nesse setor, por seu estreito vínculo com as expressões do desenvolvimento social no nivel local.

Definido o propósito da participação em relação ao desenvolvimento social e a solução de seus conflitos, considerando a participação tanto um meio como um fim em si mesma (se por 
O CONUSAN-SP E OS PARADIGMAS DA PARTICIPAÇÀO

interesses particulares, como mencionou TOURAINE 1992). A avaliação pode contribuir um movimento de transformação. Identificados os conflitos, caracterizaram-se os atores e os cenários, estabeleceram-se perguntas fundamentais que permitiram compreender a dinâmica e as condições do processo no COMUSAN-SP.

Para esse estudo utilizou-se o roteiro proposto pela OPAS (1990), inicialmente em três dimensões e posteriormente, após a pesquisa exploratória, foi adotada mais uma na reorganização do corpus da pesquisa, como detalhado na Análise dos Dados.

\section{Pesquisa com Entrevistas}

Como observado por MINAYO (1993), na entrevista utilizou-se a técnica de abordagem qualitativa que permitiu obter dados objetivos e subjetivos, que foram relacionados aos valores, atitudes e opiniões dos sujeitos entrevistados.

Trabalhou-se na técnica de entrevista com gravador. Como tratado por QUEIROZ (1983), essa técnica constitui uma abertura às investigações de todos e quaisquer grupos ou camadas sociais pouco atingidas pelos registros escritos, realçam a observação no momento em que é feita, ajuda a dar legitimidade às inferências do pesquisador. Essa técnica dá ênfase à liberdade de expressão das pessoas, aproximando-as do pesquisador (numa circunstância de afinidade com as questões levantadas).

Trabalhou-se como propõe SPINK M (1992), com a ótica construtivista, onde o sujeito foi enfocado como produto e produtor da realidade social em foco, ele foi ativo, deu sentido ao objeto de estudo, deu sentido social, material, ideológico, ele construiu representações e teorias sobre sua realidade. Descreveu-se o mundo social através de sua atividade e interação com os demais.

Para BARDIN (1977), a entrevista é uma atividade de consideração positiva e incondicional do entrevistador para com o entrevistado, tendo como única limitação o tema proposto.

A partir das questões específicas conforme o roteiro de entrevistas (anexo 02), individuais, não diretivas, e o roteiro para avaliação de atividade, na técnica do grupo focal, realizou-se a coleta de dados no campo. 
OCOMUSAN-SP E OS PARADIGMAS DA PARTICIPAÇÃO

O processo desenvolvido tanto para as entrevistas quanto para o grupo focal contou com duas partes: primeira parte, a concepção e a execução na concepção, a identificação, focalização e definição dos aspectos (variáveis) que podem determinar o nivel de participação dos atores (população alvo), procedendo à categorização prévia com base na pesquisa exploratória, e segunda parte, a elaboração de questões, conforme descritas no anexo 02.

Foram realizadas 28 entrevistas individuais, dentre os membros titulares e suplentes do COMUSAN-SP, concordantes e disponiveis, sendo que 04 (quatro) foram desprezadas devido às gravações estarem inaudiveis, dentre as 40 (quarenta) propostas inicialmente; 02 (dois) Grupos Focais, com pauta de avaliação das atividades desenvolvidas pelo COMUSAN-SP, incluindo percepções sobre participação, com 14 (quatorze) conselheiros, no total, sendo que 04 (quatro) deles estão também dentre os entrevistados;

\section{Instrumentos utilizados para as entrevistas}

- Questões semi-estruturadas e com sondagem de opiniões; roteiro em forma de questionário acompanhado de Carta de Consentimento (anexos 02 e 05); entrevistas gravadas em fita cassete; transcrições pela própria pesquisadora;

- Mapas (para facilitar a tabulação) direcionados para as entrevista (com os campos do roteiro) individuais e com grupo-focal;

- Anotações do diário de campo, com observações do grupo (sistematizadas também em mapas);

- Reuniões (estilo Grupo Focal) com pauta específica para avaliação de atividades, ressaltando-se as opiniões individuais e as coletivas, paralelamente; reuniões gravadas em fita cassete; transcrições pela própria pesquisadora.

\section{Realização das Entrevistas}

Ao iniciar as entrevistas percebeu-se algum desconforto dos entrevistados em responder questões sobre alguns dados pessoais. Sendo assim, desprezamos o primeiro campo do roteiro mantendo apenas sexo e faixa etária (aproximada) nos registros do diário de campo.

Segundo BARDIN (1977), a função de fazer descobertas da análise de conteúdo proporcionou o surgimento de hipótese quando examinamos mensagens pouco exploradas, 
OCOMUSAN-SP E OS PARADIGMAS DA PARTICIPAÇÃO

inferindo sobre esse tipo de resposta foi possivel dizer que elas sugeriram sentimentos de desigualdade nas condições ou no tratamento diferenciado na declaração de procedência, renda familiar, escolaridade além da idade e do tempo de atuação na entidade.

Os dados que registrados sobre faixa etária e ocupação, porém, corresponderam ao universo dos 80 membros do Conselho, devido à vivència cotidiana ter possibilitado registros no diário de campo.

$O$ trabalho de campo contou com a colaboração dos Conselheiros (titulares e suplentes) que se disponibilizaram para as entrevistas e para a realização do grupo focal com a técnica de avaliação do trabalho do COMUSAN-SP; contou com a equipe de apoio da Secretaria Executiva e voluntários, do serviço público municipal.

\section{2 - Método da Observação Participante}

As relações políticas e as relações pessoais permeiam essa parte da metodologia, tendo de ser mesclada com as demais, com ponderação e tolerância, tentando fugir do risco das tentações empírico-idealistas, como alertam DEMO (1999) e VASCONCELOS (1999). A dicotomia de papéis fez com que as etapas tomassem mais tempo que o previsto, dada a necessidade de desmembrá-los para efeito de estudo e análise, exigindo assim extremo empenho para cumprir o cronograma proposto e dando cobertura ao maior periodo possivel dessa $1^{a}$ gestão do COMUSAN-SP (que tem seu término previsto para dezembro de 2003). Os fenômenos sociais acontecidos sob esse aspecto metodológico são ricos e compõe uma parte não habitual, mas importante, dos recursos utilizados para o desenvolvimento dessa pesquisa.

A observação teve o seguinte trajeto:

- Observação direta dos conselheiros, durante as atividades do COMUSAN-SP;

- Análise das atas de reunião (revivendo, a cada releitura, as cenas), além da utilização do diário de campo;

- Reorganização do material, segundo a inclusão de novas dimensões e categorias, com o olhar dos conselheiros. 
O COMUSAN-SP E OS PARADIGMAS DA PARTICIPAÇÃO

\section{3 - Metodologia para Análise do Material}

\section{Análise de Conteúdo}

Esse método permitiu a associação livre de idéias, sem submeter o sujeito a regras da enunciação do discurso. Foi possivel fazer análise temática (a partir dos depoimentos) através da descoberta dos núcleos comuns de sentido, compondo uma comunicação cuja presença signifique algo para o objetivo analítico pretendido, como sugeriu MINAYO (1993).

A teoria de BARDIN (1977) permitiu o estudo das motivações, atitudes, valores, crenças, tendências políticas e ideológicas, através da técnica de categorização (com base nos discursos). Não excluiu formas de linguagem desde que atendesse à pré-análise, à descrição analítica e à interpretação do conteúdo por inferências.

BARDIN (1977) sugeriu que ao se analisar o conteúdo em determinado estudo subdividisse o material de forma organizada com algumas regras de base, conforme apresentado na tabela $\mathrm{n}^{\circ}$ a seguir. A Análise de Conteúdo relacionou as estruturas dos significantes com as dos significados e articulou os textos da pesquisa com os fatores que determinam suas características nos vários contextos, proporcionando significados das mais diversas naturezas. 
O COMUSAN-SP E OS PARADIGMAS DA PARTICIPAÇÃO

TABELA 02 : Aplicação da Análise de Conteúdo Adaptado de Bardin (1977)

\begin{tabular}{|c|c|c|c|c|}
\hline Cófigo e Syporte & Inchidual & Dialogos & Grupo Restrito & $\begin{array}{c}\text { Comnanicapato de } \\
\text { Mfassa }\end{array}$ \\
\hline $\begin{array}{l}\text { Lingüistico } \\
\text { Escrito }\end{array}$ & $\begin{array}{c}\text { Agenda } \\
\text { Diário de Campo } \\
\text {.Correspondéncia }\end{array}$ & $\begin{array}{l}\text { Questionários } \\
\text { convites }\end{array}$ & $\begin{array}{c}\text { Debates } \\
\text { Reuniões (plenas, Comissão } \\
\text { Execurva-CE,GTs) } \\
\text { Guupos de trabalho (GTs) } \\
\text { (relatórios, Atas) }\end{array}$ & $\begin{array}{l}\text { Jomais } \\
\text { Cartazes } \\
\text { Textos } \\
\text { Folderes } \\
\text { sites }\end{array}$ \\
\hline $\begin{array}{c}\text { Lingüistico } \\
\text { Oral }\end{array}$ & $\begin{array}{c}\text { Fala de conselheiro } \\
\text { Reclamações } \\
\text { Desabaios }\end{array}$ & $\begin{array}{c}\text { Entrevistas } \\
\text { Conversações formais } \\
\text { Relatos }\end{array}$ & $\begin{array}{l}\text { Reunides (plenas, CE, GTs) } \\
\text { Grupo Focal } \\
\text { Reuniòes (plenas) Gravadas } \\
\text { Eventos fechados }\end{array}$ & $\begin{array}{c}\text { Discursos } \\
\text { Publicidade (TV, } \\
\text { radio) } \\
\text { Manifestacoes } \\
\text { (campanhas.) }\end{array}$ \\
\hline $\begin{array}{c}\text { Outros Códigos } \\
\text { Semióticos }\end{array}$ & $\begin{array}{l}\text { Postura } \\
\text { Gestos }\end{array}$ & $\begin{array}{c}\text { Sinals } \\
\text { Emoç̃os expressas } \\
\text { Cobranças por smmbolos }\end{array}$ & $\begin{array}{l}\text { Repudios / apoios } \\
\text { Postura no grupo } \\
\text { Comportamento cm reunião / outras } \\
\text { auvidades }\end{array}$ & $\begin{array}{l}\text { Estereótipos (por } \\
\text { segmemto) } \\
\text { Elementos culturais }\end{array}$ \\
\hline
\end{tabular}

A organização do material obtido na pesquisa, conforme demonstrado na tabela 02 , deu-se pela divisão de código e suporte expressos pelas linguagens escrita, oral e iconográfica, sendo que cada uma dessas subdivididas de acordo com a disposição do público alvo, ou seja, individualmente, por comunicação dialogada, reuniões com grupos especificos ou através de seus meios de comunicação.

A Execução da análise de conteúdo partiu da categorização prévia para a observação dos indicadores, da reorganização das dimensões e categorias e a análise propriamente dita das respostas obtidas,.das informações coletadas pela pesquisa documental e posterior inferência.

Constituiu-se então um corpus substancial de análise, em conjunto com os demais registros do diário de campo, atas e outros documentos.

Esse procedimento contribuiu para a riqueza do arcabouço de manifestações, percepção de comportamentos e atividades que se aglutinaram em "sentidos e significados". 
O COMUS.LV.SP E OS PARADIGMAS DA PARTICIPAÇÃO

\section{Análise dos Dados}

\section{Dimensões e Categorias:}

Efetuou-se a análise de conteúdo das manifestações verbais, dos textos (atas / documentos) e das imagens, buscando a interpretação e o confronto de juízos de valor, encontrados os vários vieses e abordagens desta metodologia em função da percepção posta por BARDIN (1977).

Os procedimentos empregados para a análise de conteúdo estiveram consoantes com os objetivos do estudo. As etapas foram: a organização do material (corpus), a análise deste, com a identificação das unidades de significado, categorização e elaboração das tabelas descritivas e por fim, a interpretação das informações.

Obteve-se nesse trabalho as dimensões e categorias preliminares (anexo 03), com base na proposta da OPAS (1990). Definiu-se como unidade de contexto as entrevistas (incluindo o material do grupo focal) e as atas. Como unidades de registro foram consideradas as falas dos conselheiros, em todas as formas de expressão oral (das entrevistas, grupos focais e reuniões do COMUSAN-SP) transcritas pela autora ou aquelas reproduzidas em atas e outros documentos.

Definidas as unidades de contexto e de registro analisou-se o material coletado, seguindo a regra de exclusão mútua dos dados submetidos à codificação e categorização, admitindo apenas mais uma codificação por unidade de registro, quando coube.

As unidades foram agrupadas segundo a proximidade dos assuntos abordados e submetidas à classificação segundo as categorias e subcategorias, que fizeram o papel de indicadores, em cada dimensão da pesquisa. Esses indicadores, como definidos por KAYANO e CALDAS (2001), foram os instrumentos que serviram para medir, quantificar e qualificar a realidade social do contexto estudado. Os indicadores simples apresentaram as situações e ações no Conselho, enquanto que os indicadores compostos agruparam aspectos de forma conjunta para compor o contexto propriamente dito, permitindo assim as comparações com outras situações e contextos já analisados.

Após o grupamento e refinamento procedeu-se à escolha dos indicadores e ao reagrupamento, viabilizando a organização por categoria e suas características ou subcategorias.

Além das três Dimensões da categorização preliminar, adotou-se uma quarta, a Dimensão Estrutural que delineou o Cenário de ação do objeto de pesquisa, como os detalhes, quantificáveis, da participação: frequêencia às reuniões, número de intervenções, sistematização 
das discussões específicas da área de atuação, enumeração de propostas, disputas politicas, atividades (internas e externas) e as demais que demonstramos na seqüência.

A ordem das dimensões foi revista, iniciando-se pela Dimensão Estrutural (1), sendo seguida pela Dimensão das Condições que Determinam a Participação (2), que se processou pela sistematização das falas, como disposto anteriormente. Nas Categorias, os conceitos, traduzidos por seus valores, as oportunidades foram dispostas na forma dos indicadores: facilidades e dificuldades, motivação e discussões especificas sobre Segurança Alimentar e Nutricional e os obstáculos, conforme o indicado: dificuldades. Destacou-se do conjunto das entrevistas as falas mais expressivas em relação a cada pergunta formulada.

Para a Dimensão das Caracteristicas e Dinâmicas da Participação (3), lançou-se mão de pesquisa documental, nas Atas de reuniões do COMUSAN-SP, nos relatórios e demais documentos de seus arquivos e do "diário de bordo", produzido durante a vivência das reuniões do COMUSAN-SP (ordinárias e extraordinárias, de grupos de trabalho, comissão executiva e outras formas de organização e divisão de tarefas).

Para a Dimensão Processos e Cultura de Participação (4), utilizou-se todo o material das dimensões anteriores, mais o referencial teórico da pesquisa bibliográfica e da técnica de Avaliação (do grupo focal).

Com as diversas estratégias de pesquisa utilizadas na metodologia participativa, buscaramse formas de efetivar um estudo de cunho etnográfico avaliativo quanto a alguns aspectos do perfil e costumes dos conselheiros, na ação pesquisada, de modo a obter na investigação a facilidade de explicações sobre o objeto de estudo e seu contexto. Isso possibilitou a exploração dos elementos não previstos e a utilização de diferentes técnicas de contribuição para construção do saber coletivo sobre o mesmo.

Os condicionantes que nortearam a pesquisa podem ser encontrados sintetizados na tabela da introdução (p. 27) e no referencial teórico (p. 35). 


\section{5 - APRESENTAÇÃO E DISCUSSÃO DOS RESULTADOS}

Depois de seguidas leituras das transcrições das fitas (entrevistas e grupos focais), das Atas de reuniões, e do "arsenal" de documentos dos arquivos do COMUSAN-SP (SEMAB 2001, COMUSAN-SP 2002, 2003), selecionaram-se e processaram-se as informações, conforme as dimensões e categorias reorganizadas, para proceder à análise de conteúdo.

Discutiram-se os resultados na medida em que estes foram apresentados para facilitar a visualização e reflexão sobre os mesmos. As falas dos conselheiros ilustraram essa discussão na seqüência de cada aspecto analisado.

\subsection{Dimensão: Estrutural}

Qualquer processo que se pretenda transformado necessita ser avaliado pela sua Dimensão Estrutural. Há que se formalizar regras de funcionamento, objetivos concretos, quem são os atores, quais as condições de estrutura fisica e instrumentos de trabalho para desenvolver suas atividades a contento. Para organizar o material referente a essa dimensão utilizou-se das categorias e indicadores demonstrados na tabela 03 a seguir.

Tabela 03 - Dimensão e Categorias: Estrutural

\begin{tabular}{|c|c|c|}
\hline Dimensão & Categorias & Indicadores \\
\hline \multirow{7}{*}{ Estrutural } & a) Composição & - Segmentos \\
\hline & b) Freqüência às reuniờes & - Segmentos \\
\hline & c) Intervenções & - Inscrições para Fala \\
\hline & d) Atividades & - Internas e extermas \\
\hline & $\begin{array}{l}\text { e) Instrumentos Político-Sociais de } \\
\text { participação }\end{array}$ & $\begin{array}{l}\text { - Panticipação em Eventos } \\
\text { - Divulgação } \\
\text { - Capacitação } \\
\text { - Mobilização / pressão } \\
\text { - Ações Internas } \\
\end{array}$ \\
\hline & f) Cronograma de reuniões & - Datas e Locais \\
\hline & g) Estrutura Física & - Secretaria Executiva \\
\hline
\end{tabular}


O COMUSAN-SP E OS PARADIGMAS DA PARTICIPAÇÃO

\section{a) Composição do COMUSAN-SP}

A composição inicial do COMUSAN-SP foi estabelecida na minuta do decreto elaborada no grupo de Legislação da I Conferência Municipal de Segurança Alimentar e Nutricional de São Paulo e aprovada na Plenária Final (09/12/2001), que na seqüência elegeu os membros da $1^{\text {a }}$ Gestão para o biênio 2001-2003, dentre os participantes presentes à Conferência.

Posteriormente essa composição sofreu alteração (no segmento de governo) quando o COMUSAN-SP foi oficialmente reconhecido pelo Decreto Municipal de $n^{\circ} 42.862$ de 13/02/2003 (o decreto e as instituições que fazem parte da $1^{2}$ gestão, assim como a Comissão Executiva, constam dos anexos 06, 07 e 08. Contudo, a alteração só foi efetivada na II Conferência, acontecida em outubro de 2003 conforme anexo 11).

Sua composição tem formação tripartite, com 40 membros. Sendo que a Sociedade Civil conta com vinte conselheiros, $50 \%$ dos membros distribuídos entre: movimentos populares e comunitários; entidades que congregam prestadores de serviços e produtores de materiais para a área de alimentos; entidades patronais da área; instituições de ensino e pesquisa, privados; entidades representantes da economia informal e entidades de portadores de patologias e deficiências. Os Trabalhadores da Área de alimentação e nutrição contam com dez membros, $25 \%$, divididos entre sindicatos, associações e conselhos reguladores de profissões. O Poder Público, membros do Governo, com os restantes $25 \%, 10$ membros contemplando representações das esferas municipal, estadual e federal. Inicialmente, na $1^{\mathrm{a}}$ Gestão, dentre estes aparecia DIMA Departamento Municipal de Inspeção de Alimentos (A Vigilância Sanitária de Alimentos da SEMAB) que após o decreto foi substituido pelo MESA - Ministério Extraordinário da Segurança Alimentar. Outra mudança de representação nessa composição foi no setor de ensino superior público, a Universidade de São Paulo/ Faculdade de Medicina Veterinária e Zootecnia USP/FMVZ, com titular e suplente (representando também as Faculdades de Farmácia e de Saúde Pública) estive na $1^{a}$ gestão e na $2^{\mathrm{a}}$ gestão estão como titular a Faculdade de Saúde Pública - FSP e suplente a USP/FMVZ.

A determinação dos representantes das Instituições se deu dentro de cada segmento por eleição ou indicação, na Plenária Final das Conferências, para ambas as gestões. Coube ao Governo indicar seus representantes posteriormente. 
O COMUSAN-SP E OS PARADIGMAS DA PARTICIPAÇÃO

O Funcionamento do COMUSAN-SP foi estabelecido por Regimento Interno elaborado e aprovado por seus membros (Ata da $2^{\circ}$ Reunião Ordinária, 14/03/02). Nesse, foram estabelecidas as regras de frequència, participação formal, objetivos, definição de papeis e organização do Conselho.

As Atas, documentos que registram as reuniões ordinárias e extraordinárias do COMUSAN-SP, foram publicadas em Diário Oficial do Municipio, após sua aprovação pelos Conselheiros.

\section{Dos Conselheiros}

Como observado anteriormente o registro sobre a faixa etária constitui informação do diário de campo. Contudo, é interessante ter noção de como estão distribuídos quanto a esse dado (tabela 04).

Tabela 04: Faixa Etária dos Conselheiros (aproximada)

\begin{tabular}{|c|c|c|}
\hline FAIXA ETÁRIA & FREQUÊNCIA & $\%$ \\
\hline $20-30$ & 02 & 02 \\
\hline $31-40$ & 30 & 37 \\
\hline $41-50$ & 32 & 40 \\
\hline+50 & 10 & 12 \\
\hline Sem avalią̧ão & 07 & 09 \\
\hline TOTAL & 80 & 100 \\
\hline
\end{tabular}

A maioria, 77\%, dos conselheiros está situada entre 30 e 50 anos de idade, sendo que dos $12 \%$ acima dos 50 anos (cerca de $8 \%$ desses é de aposentados).

Importante também foi considerar o quesito sexo. As mulheres somaram maioria, com $64 \%$ da representação das Instituições dentro do COMUSAN-SP, enquanto os homens, $36 \%$ das mesmas. Essa proporção foi equivalente em relação à titularidade e à suplência. As mulheres ocuparam $62 \%$ das vagas de titulares e os homens $38 \%$. Tal fato pode ser atribuido ao 
O COMUSAN-SP E OS PARADIGMAS DA PARTICIPAÇÃO

envolvimento das mulheres em assuntos referentes a cuidados e seu papel no campo da Alimentação e Nutrição, desde os tempos mais remotos da história da agricultura.

A maior freqüència do sexo masculino aparece no segmento da sociedade civil, nos "subsegmentos" de patronais da área e economia informal, com menor distribuição nos demais setores.

\section{Ocupação dos Conselheiros em suas Instituições}

De acordo com as informações dos próprios conselheiros é possivel inferir que as ocupações dos mesmos, em relação às instituições que representam, variam entre dirigentes e "funcionários", predominando ligeiramente a ocupação de dirigente. Lembramos que os representantes de governo estão sendo considerados "funcionários da instituição". (juridicamente, no setor público, o termo funcionário é utilizado só para concursado, os demais são chamados servidores).

\section{b) Freqüência dos Conselheiros às Reuniões do COMUSAN-SP}

As reuniões do COMUSAN-SP, de acordo com o Regimento Interno foram realizadas mensalmente, em locais rodiziados dentre as sedes das instituições-membro do Conselho, com duração média de quatro a cinco horas.

Como demonstrado nas tabelas 05, 06 e 07, a seguir e nas tabelas $C$ e $D$, em anexo, considerando que no período estudado, o COMUSAN-SP realizou 22 reuniões (19 ordinárias, 02 extraordinárias e a reunião de Posse). Verificou-se o índice de presença com os seguintes cálculos: $\mathrm{n}^{\circ}$ de reuniões multiplicado pelo $\mathrm{n}^{\circ}$ de conselheiros titulares e suplentes de que cada segmento dispõe, obtendo-se os valores e porcentagens demonstrados. A Sociedade Civil com 344 presenças, das 880 de seu potencial, os Trabalhadores com 226 presenças, das 440 possiveis e - Governo 171, das 440. Detalhou-se nas tabelas as participações em freqüência de cada segmento e "sub-segmento" para saber exatamente quais instituições mais compareceram às reuniões. 
Tabela 05: Total de Presenças às reuniões do COMUSAN-SP de 02/2002 à 09/2003, por segmento / sub-segmento

\begin{tabular}{|c|c|c|}
\hline Segmentos & $\begin{array}{c}\text { Total de Conselheiros } \\
-\mathrm{T} / \mathrm{S}\end{array}$ & $\begin{array}{c}\text { Total de Reuniões e } \\
\text { Presenças }\end{array}$ \\
\hline Socriedade Civil & 40 & $* 880 / 344$ \\
\hline $\begin{array}{c}\text { Movimento Polulares / } \\
\text { Comunidade }\end{array}$ & 10 & 119 \\
\hline $\begin{array}{c}\text { Prestadores de Serviços / } \\
\text { Produtores }\end{array}$ & 01 & 34 \\
\hline $\begin{array}{c}\text { Patronais - Area de } \\
\text { Alimentos }\end{array}$ & 10 & 101 \\
\hline $\begin{array}{c}\text { Ensino e Pesquisa - } \\
\text { Privados }\end{array}$ & 06 & 40 \\
\hline Economia Informal & 04 & 06 \\
\hline Trabalhadores da Área & 20 & $* * 440 / 226$ \\
\hline Sindicatos & 06 & 74 \\
\hline Associações & 08 & 83 \\
\hline Conselhos & 06 & 69 \\
\hline Governo & 20 & $* * 440 / 171$ \\
\hline SEMAB & 02 & 23 \\
\hline DIMA & 02 & 32 \\
\hline SMS & 02 & 24 \\
\hline SME & 02 & 13 \\
\hline SAS & 02 & 28 \\
\hline SES & 02 & 01 \\
\hline$S A A$ & 02 & 10 \\
\hline CEETEC & 02 & 29 \\
\hline USP/FMVZ & 02 & 10 \\
\hline MS & 02 & 01 \\
\hline
\end{tabular}

Fonte: Listas de presenca do COMUSAN-SP de fevereiro de 2002 a satembro de 2003

(rauniōes ordinárias, extraordinárias, posse - 22 reuniōes $X 40$ membros $\mathrm{T} / \mathrm{S} \quad * * 22$ rauniỏes $\mathrm{X} 20$ membros $\mathrm{T} / \mathrm{S}$ ) 
O COMUSAN-SP E OS PARADIGMAS DA PARTICIPAÇÃO

Tabela 06: Consolidado de Participações em reuniões do COMUSAN-SP, por Segmento, em Número e Porcentagem, no periodo de fevereiro de 2002 a setembro de 2003.

\begin{tabular}{|c|c|c|c|c|c|}
\hline Participantes & $\begin{array}{c}\text { Sociedade } \\
\text { Civil }\end{array}$ & Trabalhadores & Governo & Total & Potencial \\
\hline $\begin{array}{c}\text { Total de titulares } \\
\text { E suplentes }\end{array}$ & 344 & 226 & 171 & 742 & 1760 \\
\hline Porcentagem & $39,09 \%$ & $51,36 \%$ & $38,86 \%$ & $42,15 \%$ & $100 \%$ \\
\hline
\end{tabular}

Fonte: listas de presença das reunióes ordinárias do COMUSAN-SP

De acordo com o potencial de frequência de cada segmento o que mais participou de reuniōes foi o dos Trabalhadores da área de alimentação e nutrição, com mais da metade das presenças possíveis, seguidos pelos segmentos da Sociedade civil e Governo, estes de forma equilibrada, contudo, com menos da metade das presenças esperadas.

Além dessas constatações, observou-se também que apesar de o segmento da Sociedade Civil ter comparecido menos que o dos Trabalhadores, ambos prestigiaram mais suas representações tendo seus titulares presentes em porcentagem maior que o Governo, que compareceu às reuniões na maioria das vezes representado por seus suplentes (tabela 07).

Tabela 07: Participações e Porcentagem, por segmento, de titulares e suplentes, às reuniões do COMUSAN-SP, no período de fevereiro de 2002 a setembro de 2003.

\begin{tabular}{|c|c|c|c|}
\hline Participantes & $\begin{array}{c}\text { Sociedade } \\
\text { Civil }\end{array}$ & Trabalhadores & Governo \\
\hline titulares & 213 & 143 & 49 \\
\hline Porcentagem & $48,4 \%$ & $65 \%$ & $22,27 \%$ \\
\hline suplentes & 131 & 83 & 122 \\
\hline Porcentagem & $29,77 \%$ & $37,72 \%$ & $55,45 \%$ \\
\hline
\end{tabular}

Fonte: listas de presença das reuniōes do COMUSAN-SP 
O COMUSAN-SP E OS PARADIGMAS DA PARTICIPAÇÃO

\section{c) Intervenções dos Conselheiros nas Reuniões do COMUSAN-SP}

Embora os Trabalhadores tenham freqüentado mais as reuniões (seguidos da Sociedade Civil e do Governo, com porcentagens semelhantes entre si - 39,09\% e $38,86 \%$, respectivamente) não foram os que mais fizeram intervenções, ou seja, fizeram uso da expressão oral, registrada em Ata. O Governo destacouse com $39,48 \%$ das intervenções, seguidos pela Sociedade Civil, com $35,22 \%$ e pelos Trabalhadores, com $25,29 \%$.

Tabela 08: Intervenções em reuniões ordinárias e extraordinárias do Conselho, entre fevereiro de 2002 e agosto de 2003.

\begin{tabular}{|c|c|c|c|}
\hline Participaç̃es & Sociedade Civil & Trabalhadores & Governo \\
\hline Intervenções & 273 & 96 & 153 \\
\hline Porcentagem bruta & $52,10 \%$ & $18,70 \%$ & $29,20 \%$ \\
\hline $\begin{array}{c}\text { Porcemagem proporciơnal } \\
\text { ao segmento }\end{array}$ & $35,22 \%$ & $25,29 \%$ & $39,48 \%$ \\
\hline
\end{tabular}

Fonte: Atas das reuniōes ordinárias e extraordinárias do COMUSAN-SP

WENDHAUSEN (2002) ao analisar um Conselho de Saúde, observou que a maior freqüência de intervenção do segmento governamental estava associada à forma de condução das reuniões e da disposição dos conselheiros nessas, "espaço quadriculado, cada um em seu lugar" (p. 202), justificando também a separação e distância entre os conselheiros e o presidente.

As reuniões do COMUSAN-SP, na disposição do espaço, seguiram a estrutura física dos locais disponibilizados para as reuniões, diferente do citado por WENDHAUSEN (2002), sempre que possivel em forma circular, todos visualizando a todos. Embora o regimento interno preconize que a coordenação tenha de ser feita pelo Presidente, na maioria das vezes se instalou uma mesa coordenadora, com os membros da Comissão Executiva pertencentes aos segmentos que compõe o Conselho, freqüentemente presidida pela Coordenação da Comissão Executiva, como consta das atas e das entrevistas. 


\section{d) Atividades do COMUSAN-SP}

Foi possivel observar que as atividades foram intensas. Como relacionadas na tabela 09, a seguir, os Indicadores Formais de Participação (de dezembro de 2001 a setembro de 2003), retratam as atividades formais do COMUSAN-SP. As principais aconteceram no cotidiano do próprio Conselho, no decorrer das reuniões ordinárias, durante as discussões sobre assuntos de seu interesse, na interação entre as instituições e seus representantes, na troca de experiências e de saberes como diria FREIRE (2000). Essa troca possibilitou a produção de inúmeras outras atividades, intercâmbios, cursos de formação, somatória de esforços para fazer propostas que conjugaram interesses de várias partes, como nos grupos de trabalho e nas comissões. A visibilidade, como reclamaram os Conselheiros (em entrevista), nem sempre correspondeu ao que gostariam, mas, sempre resultou em bons frutos, como sua projeção no Fórum Interconselhos e a ampliação do número de participantes na II Conferência Municipal de Segurança Alimentar e Nutricional de São Paulo, com um resultado diferente de propostas e a eleição de inúmeras instituições novas para membros do Conselho (anexos 12 e 13).

A sistematização das atividades do COMUSAN-SP foi possivel devido aos registros dessas nas Atas, através dos informes dos Conselheiros e suas deliberações, e também devido ao produto das entrevistas com os mesmos. 
O COMUSAN-SP E OS PARADIGMAS DA PARTICIPAÇÃO

Tabela 09: Indicadores Formais de Participação (de dezembro de 2001 a setembro de 2003)

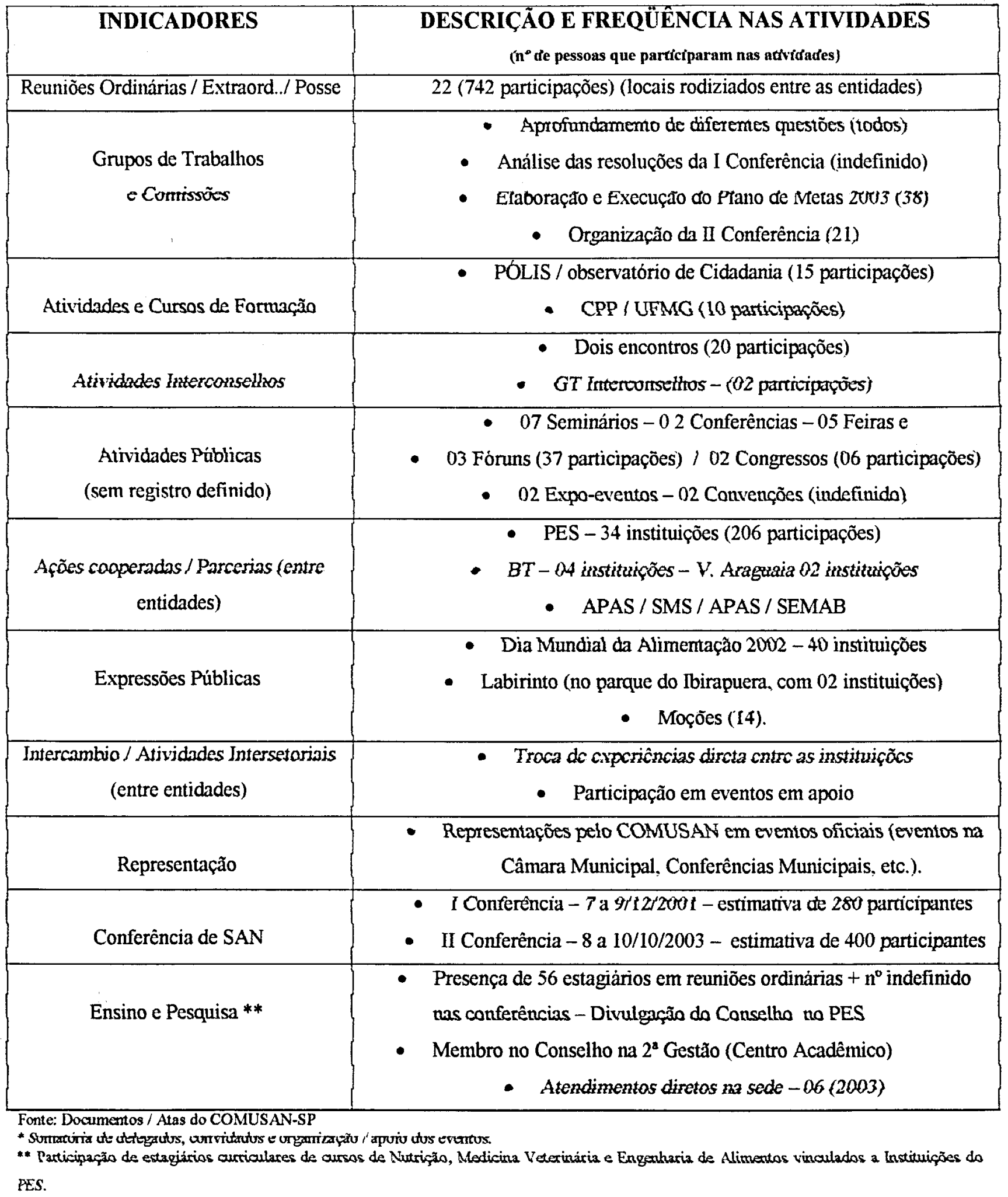




\section{e) "Instrumentos Político-sociais de Participação Cidadã"}

Outras formas de intervenção foram encontradas nos registros arquivados no COMUSANSP (Atas e outros documentos), no diário de campo e através das entrevistas. A participação pode ser traduzida por uma evidente preocupação pelo reconhecimento público das ações dos membros do Conselho, como demonstrado na tabela 10 (a seguir) adaptada da PJ e CPT (2001), que sintetizou os "Instrumentos Político-sociais de Participação Cidadã". Publicações das Atas e Comunicados no Diário Oficial do Municipio, notícias sobre o COMUSAN-SP nos veículos de comunicação das Instituições, membros do Conselho, participações dos Conselheiros em eventos apresentando propostas ou divulgando trabalhos, seja representando o Conselho ou a própria instituição. Mais outra forma de intervenção foi percebida nos resultados, a participação em cursos de formação, aceita positivamente por todos que utilizaram os acessos disponiveis.

Embora muitos Conselheiros contestem a eficácia desse instrumento, o que expressou maior número de intervenções em caráter coletivo foram as ações em Grupos de Trabalho ou em Comissões para cumprir as tarefas deliberadas pelo Pleno do Conselho. Os resultados mais evidentes estão demonstrados no Plano de Metas (anexo 09) e nas Propostas de funcionamento do próprio Conselho (Regimento Interno, análise das propostas da I Conferência Municipal de Segurança Alimentar e Nutricional de São Paulo, estrutura e organização da mesma e da II Conferência, organização de atividades comemorativas para o Dia Mundial da Alimentação, Avaliação da atuação do Conselho em 2002, dentre outros trabalhos). 
Tabela 10: Instrumentos Político-Sociais de Participação do COMUSAN-SP

\begin{tabular}{|c|c|c|}
\hline Instrução & Descrição & Participantes \\
\hline Divalgąãa & $\begin{array}{l}\text { D.O.M., BIs, Revistas das entidades, Imprensa (SMCIS, } \\
\text { SEMAB-G, Sitio da PMSP) } \\
\text { Cartazes, Folderes, Bunners, Faixa, fotos }\end{array}$ & Todos \\
\hline Capacitą̧ão & $\begin{array}{c}\text { Manual do Conselheiro } \\
\text { Texto técnico, legislação, Cartilhas } \\
\text { Avaliação 2002, Plano de metas } \\
\text { Cursos de Formação para Conselheiros - POLIS e CPP } \\
\text { Oficina RJ }\end{array}$ & $\begin{array}{l}(80) \\
(41)\end{array}$ \\
\hline Expressão Simbótica & $\begin{array}{c}\text { Dia mundial da Alimentação e } \\
\text { Café da manhã na Praça da Sé para } 5000 \text { pessoas (25) } \\
\text { cores) com ato Ecumênico / } 60 \text { voluntários } \\
\text { e cerimônia oficial }\end{array}$ & $\begin{array}{c}(25) \\
(60) \\
(5000)\end{array}$ \\
\hline Iconográfico & Arquivo fotográfico de atividades do COMUSAN & Todos \\
\hline Mobilização e Pressão & $\begin{array}{c}\text { - Mfợões das Conferências I e II } \\
\text { - Moções do COMUSAN - ACELBRA, Transgênicos, } \\
\text { canão telefônico-2002 } \\
\text { - Campanha SAN - 16/10/2002 (Folder) }\end{array}$ & $\begin{array}{c}(14) \\
(1) \\
(500)\end{array}$ \\
\hline Ações Imernas & 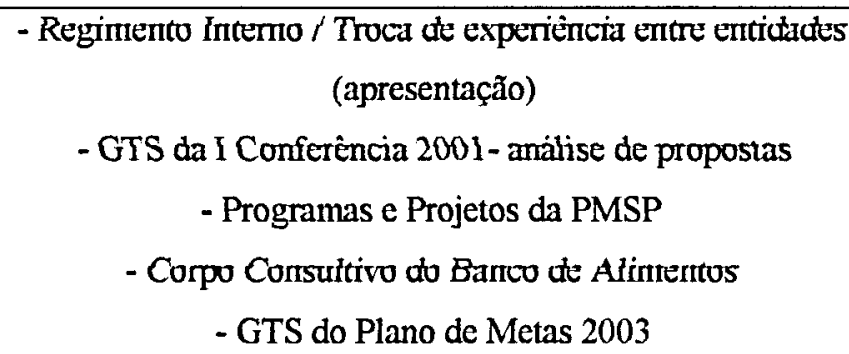 & Todos \\
\hline
\end{tabular}




\section{f) Cronogramas de Reuniões (Datas e Locais)}

Atendendo ao Regimento Interno do COMUSAN-SP as reuniões foram mensais, como mencionado anteriormente, e conforme deliberação de seu Pleno, na segunda quinta-feira do mês, na $1^{\text {a }}$ Gestão das 09:00h às 14:00h; na $2^{\mathrm{a}}$ Gestão, das $08: 00$ às 13:00h, ou em outro horário por ele alterado. A duração média das reuniões tem seguido a prevista. As reuniões da Comissão Executiva na $3^{\mathrm{a}}$ quinta-feira do mês, para encaminhar ou colocar em prática as deliberações do COMUSAN-SP. O cronograma de reuniões foi estabelecido pelo Pleno, com calendário anual, proposto e votado na primeira reunião ordinária do ano, sofrendo alterações apenas por decisão do próprio Conselho.

Os locais foram definidos em cada reunião, através da escolha dentre os locais disponibilizados pelos próprios Conselheiros, conforme acomodações e disponibilidades de suas instituições. Esse rodízio seguiu estratégia do Pleno de envolver as Instituições no cotidiano do Conselho. Os locais e datas das reuniões do período da pesquisa encontram-se na tabela *, em anexo, que sistematiza as Pautas das reuniões do COMUSAN-SP.

Os dados revelaram que a dinâmica das reuniões favoreceu o convivio entre as instituições como discutido mais à frente.

\section{g) Estrutura Física do COMUSAN-SP}

No inicio das atividades do COMUSAN-SP, a Secretaria do mesmo funcionou junto ao DIMA, na Seção Técnica de Educação Sanitária, contando com a colaboração da Equipe técnica da referida seção. Com o tempo, a Comissão Executiva do Conselho, através de pressão política ao Presidente, também Secretário Municipal do Abastecimento, conseguiu sede independente, em acomodações no prédio do Gabinete da Secretaria. Acompanhando a conquista da nova sede, pessoal administrativo, equipamento de informática e material de consumo para desenvolver suas atividades burocráticas, além de abrigar a Coordenação da Secretaria Executiva do Conselho.

Essas condições melhoraram, em parte, os acessos e a comunicação dos membros do Conselho com o Executivo Municipal, inclusive o apoio financeiro necessário para realizar algumas de suas ações como a realização da II Conferência Municipal de Segurança Alimentar e Nutricional. 
OCOMUSAN-SP E OS PARADIGMAS DA PARTICIPAÇÃO

Coube incluir aqui a disponibilidade das instituições em sediar as reuniões ordinárias do COMUSAN-SP ampliando (e diversificando) a estrutura fisica para o desenvolvimento de suas atividades.

\section{Dimensão: Candições que Determinam a Participação}

Essa dimensão estabelece referências iniciais para observar os conceitos e os efeitos da participação em comparação às oportunidades e obstáculos, tanto internos como externos, que os conselheiros vivenciam nos processos participativos, como detalhado na metodologia. As falas selecionadas receberam destaques nos termos mais importantes (os positivos em negrito e os negativos sublinhados).

Tabela 11 - Dimensões e Categorias: Condicionantes que Determinam a Participação

\begin{tabular}{|c|c|c|}
\hline Dimensão & Categorias & Indicadores \\
\hline & a) Conceito & Definições \\
& & Valores \\
\cline { 2 - 3 } $\begin{array}{c}\text { Condicionantes que determinam a } \\
\text { participação }\end{array}$ & b) Oportunidades e Obstáculos & $\begin{array}{c}\text { Facilidade } \\
\text { Dificuldade } \\
\text { - Motivação }\end{array}$ \\
\hline
\end{tabular}

\section{a) Conceito}

Para detectar como os Conselheiros conceituaram participação, analisou-se o resultado do rol de perguntas com esse objetivo. Quando perguntado aos Conselheiros o que pensavam sobre participação o que se observou nas respostas foi que têm concepções genéricas. Relacionaram participação à união, esforços para um bem comum, colaboração. Poucos associaram à obtenção de informações ou busca por melhores condições de vida, no âmbito social mais geral. A maioria também demonstrou que tem pouca experiência de participação em Conselho, tendo seu conceito 
O COMUSAN-SP E OS PARADIGMAS DA PARTICIPAÇÃO

referenciado na participação em sua instituição, diversificada pelos objetivos que tenham e pelo segmento a que pertencerem.

... Participar é unir a todos as pessoas que tem uma meta de participação em prol da comunidade. das entidades e da própria cidade de SP...(01)

... Participação para mim é eu trabalhar dentro daquilo que tenho condições de trabalhar, procurando atender aos objetivos do conselho ou do lugar onde estou, dar efetivamente meu trabalho pessoal dentro daquilo que tenho condição de trabalhar ou de doar.(02)

... Participação para mim é me interar dos assuntos que são discutidos, discutir em paralelo com algumas pessoas que já tenho um relacionamento e depois discutir em grupo...(03)

As respostas obtidas à pergunta sobre o que a instituição do Conselheiro pensa sobre participação confundiram-se com o próprio pensamento do Conselheiro, que, muitas vezes verbalizou que a entidade nunca discutiu o que seja participação. A defesa de participação, reivindicação antiga no exercício da cidadania, nos diferentes espaços da Sociedade, não apareceu de forma expressiva nas falas. Provavelmente o ocorrido encontre justificativa no fato de a maioria dos membros não ter parte nos movimentos para criação dos conselhos. Já os membros do Governo, em grande parte, disseram que estão cumprindo uma determinação de sua instituição, que tem como estratégia a gestão participativa, e não tem muito claro o conceito de participação em sua representação.

... Sou representante do Governo, que (sic) como ela é propagadora dessa questão da participação popular, eu acredito que ela pensa que essa é uma forma de governar com jeito moderno, diferenciar, ouvir o que as pessoas querem em voz de impor determinadas situações... (04)

... Não foi discutido dentro da entidade(05)

... Pensa da melhor forma de participar... vencer as dificuldades...(06) 
O COMUSAN-SP E OS PARADIGMAS DA PARTICIPAÇÃO

Suas opiniões a respeito do que seja preciso para participar bem enumeraram condições que envolviam suas próprias disponibilidades e seu conhecimento sobre a causa a ser defendida, poucos expressaram, no momento dessa resposta, critérios externos para tratar da qualidade da participação, com exceção dos representantes de Governo, que revelaram ser apenas interlocutores, sem autonomia nas decisões e algumas vezes pensando de forma diferente desse, como será visto mais adiante.

... boa vontade... ter uma meta de participação... objetivos (07)

... disponibilidade pessoal... vontade... percepção das necessidades ... vontade em contribuir...(08)

... saber o que está fazendo naquele local... ter consciência do que sua entidade espera que você leve para o conselho...(09)

\section{b) Oportunidades e Obstáculos}

As perguntas foram elaboradas de modo que cercassem a percepção dos Conselheiros quanto ao conceito de participação (quanto ao paradigma da participação que poderia ser enquadrado) expressando-o também através da percepção de oportunidades e obstáculos. Quando questionados sobre as facilidades ou dificuldades que se tem para participar, de modo geral, novamente associaram a participação à disponibilidade pessoal e à vontade de defender causas de outras pessoas, que não só as próprias. Incluiram nessa reflexão até as características da cidade de São Paulo enquanto mega metrópole. A escala de valores, prioridades e condições pessoais aparecem como facilidade ou dificuldade.

... Disponibilidade de tempo... Priorizar outra atividade remunerada

... percepção exata do seu papel no Conselho, o que é e como ela pode participar... fazendo ligações com sua entidade e com sua entidade pode efetivar (010)

... Facilidade tem todas, é só vontade de participar... (011)

Dificuldade existe (sic) várias... Existe pouco conhecimento do que é participação... Falta esclarecimento (011) 
O CONUSAN.SP E OS PARADIGMAS DA PARTICIPAÇÃO

... as facilidades... estão no campo pessoal, são relações interpessoais, vão favorecendo a criação do espaço...por afinidades se unem... pontes de amizades... (012)

... dificuldade: numa cidade com São Paulo $1^{\circ}$ horário... $2^{\circ}$ relevar o grau de importância que esse conselho tem para elas... (não priorizar)... o Conselho ainda não faz parte das coisas mais importantes...(012)

As respostas à pergunta anterior se confirmaram quando a seguinte foi feita: quais as facilidades ou dificuldades para você participar? As condições pessoais se sobressairam. Alguns ressaltaram que foram levados a participar por outros companheiros ou tiveram a "função" delegada por seu "superior", como no caso de membros do Governo.

... Facilidade tenho bastante... dificuldade nenhuma(013)

... Me sinto automaticamente inserida... tive acesso fácil a vários eventos, a varias questões... a facilidade que abriu uma porta para outro conhecimento... .(014)

...dificuldade pessoal de me colocar... por representar um governo que tem ideologias politicas das quais nem sempre eu participo... as vezes... eu não sabia se aquilo seria uma coisa que eu estava representando ou o governo...(014)

... as vezes, disponibilidade de tempo... atividade paralela (015)

Os Conselheiros tiveram dificuldade em responder sobre quais seriam as facilidades ou dificuldades de sua entidade em participar. Notou-se que tem pouca discussão sobre como participar ou de estratégias de relacionamento com outros representantes. Apenas souberam afirmar que seria importante participar e justificaram a sua própria participação.

... tenho dificuldade em falar da entidade... opinião pessoal... extremamente importante a participação do profissional é a questão trabalhista, então as questões de Segurança Alimentar acabou (sic) não tendo muito eco.. .(016)

... entidades de classe que congregam profissionais... segurança alimentar... dar sua opinião de contribuição... questão mais técnica (016) 
OCOAUSAN-SP E OS PARADIGMAS DA PARTICIPAÇÃO

As definições de como foi Participar do Conselho e quais as facilidades ou dificuldades que têm encontrado ao participar do conselho refletiram a pouca experiência mencionada anteriormente. Alguns puderam comparar os objetivos do Conselho e sua participação, mas a maioria demonstrou em suas falas que teve uma sensação de acolhimento, foi um prazer, um aprendizado.

... é produzir palestras públicas... ainda é meio teórico... não sei qual caminho... no curso de formação... ficou mais claro... uma forma de governar... implementação de palestras públicas... (sic) ou de governo. (017)

... para mim é muito bom... como eu participo de todo sistema comunitário... mais denso como é... no COMUSAN-SP existe problemas, mas aonde não existe problema, não precisa participar... tenho sido bem acatado... (018)

$\ldots 1^{\circ}$, tempo, as vezes tenho que priorizar outras atividades, $2^{\circ}$ como estar operacionalizando, falta clareza, acho minha presença importante, acho que estou aprendendo. momento de aprendizado... vai chegar o momento (019)

... sintetizar numa forma exata de agir dentro do conselho...

As dificuldades, como antes, foram colocadas no campo pessoal.

Existe uma dificuldade, procuro (sic) a grande carga de trabalho da entidade, que é pequena em estrutura humana e um pouco grande em trabalho, sobrecarrega as pessoas... 035

No relacionamento com o outro o conceito de participação fica ainda mais disperso. Quando questionado com quem mais (e / ou melhor) se relaciona no conselho, as respostas surpreenderam. O relacionamento que deveria ser entendido como entre instituições ou entre segmentos, foi entendido como pessoal. Deu-se por afinidade profissional, não só entre os Profissionais da Área de Alimentacão e Nutrição, mas também com os profissionais afins que estão representando o segmento Governo. Tal acontecimento deu margem a dupla interpretação, as questões de cunho técnico não terem sido suficientemente discutidas com os membros da Sociedade Civil, possivelmente leigos ou com outro entendimento sobre os temas especificos 
O COMLIS.N-SP E OS PARADIGMAS DA PARTICIPAÇÃO

tratados, e numa segunda hipótese, que as questões políticas, de interesse das categorias profissionais envolvidas, tenham tido encaminhamentos direcionados conforme seu proveito.

... Näo tenho diferenças de relacionamento com quem eu mais me relaciono é com quem já trabalho, é identificação, desde que haja objetividade em comum. há uma troca... 021 (nominou pessoas de cada segmento) 022

... me relaciono bem com o pessoal do meu nível profissional que são da área... por espanto metu... entidades da sociedade civil... me esforço para pensar como eles. 023

No que se refere às instituições na questão 'o que você acha das outras entidades e da participação delas no COMUSAN-SP' houve críticas em relação às expectativas exclusivistas de alguns representantes e à falta de experiência de outros, no início da $1^{a}$ Gestão. Atribuiram esses problemas à diferença de pensamento, à falta de formação política para atuar no Conselho e à falta de entendimento do que fosse o papel de Conselheiro. Aqui se confirma o constatado por TATAGIBA (2002, p. 69 e 70) ao analisar os Conselhos Gestores e a Democratização das Politicas Públicas no Brasil: "o reconhecimento unânime da falta de capacitação dos conselheiros, tanto governamentais quanto não-governamentais, para uma intervenção mais ativa no diálogo... no interior dos conselhos. $\mathrm{O}$ problema da falta de capacitação atinge de forma diferenciada os distintos atores que participam dos conselhos. Se o acesso às informações e o próprio conhecimento quanto ao funcionamento da máquina administrativa colocam os conselheiros governamentais em vantagem em relação aos representantes da sociedade civil, entre estes últimos, as diferentes capacidades também oferecem obstáculos à igualdade de participação nos processos".

... na formação veio trazendo $l^{\circ}$ as expectativas que cada entidade dessa tinha para sua própria entidade... foram colocados os problemas... é óbvio que mum conselho com 40 pessoas pensando diferente, a coisa não andou com muita facilidade e porque não tinha um perfil ainda traçado... as pessoas começam a levar as suas questões... desviavam do assunto... elas não tinham esse entendimento... algumas entidades ainda tem uma posição bem inflexivel... (024) 
O COMUSAN-SP E OS PARADIGMAS DA PARTICIPAÇÃO

... varias delas eu achei muito bom, várias outras ineficientes por parte da entidade ou do participante... (025)

... as outras entidades como a minha . ainda não tem clareza de seu papel dentro do Conselho... precisa curso de formação logo de cara para que as pessoas tenham clareza de seu papel e da maneira como deve encaminhar os assuntos dentro do conselho, como fazer a ligação do conselho com a sua entidade... muitas vezes acabou levando questões pessoais essa coisa ainda não está muito clara para todas as entidades... (026)

Apesar de os Conselheiros terem criticado a falta de preparo dos representantes das instituições e a falta de entendimento do que fosse o papel de conselheiro ao serem questionados sobre como tem sido sua participação no COMUSAN-SP e o que sua entidade pensa sobre sua participação, responderam que sua participação foi positiva e disseram que sua instituição também estava satisfeita, ressalvados alguns casos em que o representante não tinha esse retorno.

... em relação a mim tenho achado muito boa, ótima, não sei como o conselho está recebendo essa minha participação. 027

... não sei, vou ficar devendo essa opinião... não houve esta interlocução que é o motivo da minha dificuldade... nem sempre sei o possivel e o que pensa da minha participação neste conselho. 028

... acho muito boa, me dá toda a autonomia para que aconteça o nosso objetivo $w$ me incentiva sempre... me apóia... 029

...Acho extremamente importante, estão (a entidade) muito feliz da gente estar aqui no COMUSAN. tudo aquilo que solicitei... se colocou à disposição... receptividade... apoiavam... aprovando minha representação. 030

Quando argüidos sobre como conseguem dar retorno dos resultados do COMUSANSP para suas instituições a maioria respondeu que o faz em reunião da mesma. Os membros de governo têm de marcar audiência ou reunião com seus superiores, isso ocorre com certa dificuldade devido às suas agendas sempre cheias, deixando aqui uma questão a ser aprofundada mais adiante: que importância o governo dá a essa representação? 
O COMUSAN-SP E OS PARADIGMAS DA PARTICIPAÇÃO

... repasso em reuniões da entidade (031)

... através das reuniões da entidade... as pautas são fechadas ... muitas vezes não consigo trabalhar as questões de segurança alimentar. mas dou uma encaixada e coloco a entidade a par do que está acontecendo. (031a)

se não consigo... o retorno é de domínio público, o resultado disso vai para dentro de uma ata que é pública em D.O.M. e as pessoas nominadas nas suas falas... é transparente... (032)

No momento em que se tratou sobre o que seria precisa para participar melhor no conselho o investimento em formação foi valorizado. Ficou mais nitido o motivo de porque relacionaram o conceito de participação ao comparecimento em cursos, palestras, seminários. Deduziram que assim estariam se capacitando para intervir com maior compreensão das questões a serem tratadas no Conselho.

... outro curso de formação (033)

... boa etapa disso eu já cumpri, foi participar de uma série de eventos que me ensinasse como que é que funciona um conselho, se bem que ainda não é uma coisa formada dentro da convivência do jeito brasileiro de ser... busca sempre seus interesses pessoais... não é levar o que você quer e trazer um retorno para si, é o que levar para ajudar mesmo, nos conselhos mais antigos isso existe... estou vendo por que... São movimentos dentro do conselho. que é a questão da auto-ajuda. se não dá para fazer no conselho vamos fazer nós, esta entidade e aquela. Isso eu acho muito importante para São Paulo. (034)

A temática Segurança Alimentar, assunto específico do COMUSAN-SP, também foi aferida por uma das questões feitas aos conselheiros como indicador para participação: 'Você conhecer bem os assuntos tratados no conselho?' 'O que você precisa para conhecer mais o trabalho do COMUSAN?' Contrário ao que foi dito em relação ao preparo dos conselheiros para participar de um Conselho, politicamente, todos disseram conhecer a temática especifica por estarem lidando com o assunto em sua instituição, além de vários serem profissionais da área. Contudo, todos também acham importante ampliar esses conhecimentos e trocar experiências, por 
O COMUSAN-SP E OS PARADIGMAS DA PARTICIPAÇÃO

acharem que não dão conta de uma defesa eficiente e eficaz de seus objetivos. Suas falas tanto nas entrevistas como nas Atas confirmam a afinidade declarada, porém, não refletem em mudanças significativas nas politicas públicas ou de governo, pois as discussões implementadas ficam mais no campo da reflexão e do entendimento (técnico ou filosófico). Nessa constatação pode-se inferir, com o auxílio da fala de WENDHAUSEN (2002) que "o segmento governamental que detém (e retém) determinados saberes, de modo que outros segmentos, principalmente o dos usuários [sociedade civil], ficam impossibilitados de exercer, de fato, o poder ou a resistência, que teriam de direito, isto é discutir e deliberar sobre a saúde [alimentação e nutrição] do Município (p.273)". Faz-se necessário evocar o Regimento Interno do COMUSAN-SP que exclui o caráter deliberativo do mesmo.

... conheço, principalmente qual o objetivo desse conselho, qual deveria ser ao perfil desse conselho, mas nós ainda não atingimos esse objetivo... (036)

... com relação a inocuidade de alimentos com certeza, com relação ao acesso e disponibilidade eu tenho algumas dificuldades, preciso de outros profissionais da produção, está muito centrada na mesa é o final da cadeia... (037)

... Razoavelmente bem... (038)

... quero me aprofundar um pouco mais no papel das entidades que fazem parte do meu conselho, um pouco mais de conhecimento dos meus interlocutores dentro do conselho...(039)

... precisamos que o conselho todo se reunisse sempre na hora certa para trocar experiências... (040)

... curso de formação de conselheiro. Conheço mais por ter participado desde sua criação. talvez eu precise me envolver mais e de uma forma diferente, talvez eu tenha de me inserir de outra forma, me sentir mais produtiva, esse é meu problema...(041)

Ao se pesquisar se o Conselheiro tem se preparado para sua participação no COMUSAN-SP e como se deparou com algumas pessoas que definem o preparo para uma reunião do Conselho como ler as Atas anteriores, textos referentes aos temas a discutir, mixar essas informações com os interesses da instituição que representam e assim argumentarem e defenderem seus pontos de vista com segurança. Para outros é o simples ato de comparecer e falar 
O COMUSAN-SP E OS PARADIGMAS DA PARTICIPAÇÃO

o que pensam, até mesmo sem conhecimento prévio do que ficou de ser tratado. As posturas são as mais variadas. Notou-se que esse preparo vislumbra também a importância que se dá à participação ou quanto se acredita nela, pois houve conselheiro que confessou (diário de campo) nem ter lido o Regimento Interno. Confirmou-se nesse aspecto (e em alguns anteriores, também) o que membros de outros Conselhos Municipais apontaram como problema no Fórum de Democracia Participativa (anexo *) - "confusão das lideranças (sic) sobre os objetivos, falta de esclarecimento e falsas expectativas."

Ás vezes não, eu deveria ler as atas e os documentos para vir mais preparado, eu não faço parte da Comissão Executiva, às vezes me sinto um peixe fora d'água, vejo que as pessoas conversam entre si assuntos que demora eu perceber sobre o que se trata, eu leio a pauta. não venho tão despreparada assim, mas a pauta é uma linha, não sei onde se quer chegar, talvez eu me candidate à executiva... (042)

... com certeza tenho me preparado, o preparo é tirar do nosso próprio trabalho de segurança alimentar, do meu trabalho, os subsidios para entrar no COMUSAN com essa bagagem. da própria entidade... (043)

Acho que sou uma das pessoas que tem se preparado, $I^{\circ}$ por que tenho curiosidade inata de descobrir as coisas, $2^{\circ}$ que todas as oportunidades que me foram dadas de aprender como funciona um conselho, informações, tenho buscado todas as possiveis... (044)

\section{Motivação}

Depois de avaliada a freqüência e as intervenções dos conselheiros, ter notado o fato de todas as reuniões ordinárias terem tido quorum e ter acontecido um grande número de intervenções, permeadas por todos os segmentos e por assuntos pertinentes ao funcionamento e objeto do COMUSAN-SP, foi possivel deduzir que houve motivação para as participações. $\mathrm{Na}$ análise do exercício do Conselho, através da técnica de avaliação pelo Grupo Focal, e na pesquisa das Atas ficou evidente o envolvimento dos segmentos, a maioria esteve motivada durante todo 0 tempo. Quando faltou motivação a alguns (também expresso nas falas) os demais trataram de encontrar estratégia para que voltassem a ficar motivados.

Como o Conselho é consultivo a partilha do poder não apareceu como motivação, como em outros conselhos (CORREIA 2000). O aprendizado, o ato de partilhar, o interesse da troca de 
O COMUSAN-SP E OS P.ARADIGMAS DA PARTICIPAÇÃO

experiência, a união de esforços, o aprofundamento de discussões sobre a temática especifica, o fato de ver pessoas envolvidas e a sensação de acolhimento foram as principais motivações.

A seguir, as falas dos Conselheiros que exemplificam essas motivações e as estratégias para motivar a participação no COMUSAN-SP:

\section{... Aprendizado 047}

...Fiquei sem ter pessoas para partilhar, imaginando politicas e programas que minha profissão pudesse oferecer, por isso me empenhei para levar gente à (II) Conferência. (048)

... Curiosidade muito grande em saber como o outro pensa e até fazer um esforço para pensar igual (049)

... As pessoas aprendendo a caminhar de uma forma paralela, não junto, mas elas já conseguem ter uma direção única (050)

... Por que tem uma direção, se não, não tinha durado nem nove meses (051)

... Oportunidade inica de conhecer outra entidade, de saber o que elas fazem, como funcionam (052)

... Tinha gente que vinha com mais pressa, por que já fazia parte de um movimento e já quer chegar lá na parte mais rápida, meio ansiosas, agora conseguiram sincronizar passos de cada um no conselho, fantástico (053)

... Participar da construção do COMUSAN (054)

... Unir esforços, participar, vencer as dificuldades (055)

... Ser bem recebida a toda reunião, ver boa vontade (056)

... Ver nosso esforco reconhecido pelos colega... poder divulgar o que nossa entidade faz (057)

... Aprofundar discussão de Segurança Alimentar e Nutricional dentro da entidade (058)

... Expectativa inicial, ação e resultado (059)

... Os que ficaram são pessoas envolvidas para seus próprios motivos, pelas amizades, enfim me sinto extremamente desanimada (060)

... Participar do "ciclo de formação de conselheiros" foi muito importante por que conheci as dificuldades e problemas de outros conselheiros (061). 
O COMUSAN-SP E OS PARADIGMAS DA PARTICIPAÇÃO

Pensando-se que o roteiro utilizado poderia calar alguma fala que elucidasse os objetivos apontados, acrescentou-se uma questão para libertá-la: Quer falar alguma coisa que não tenha sido perguntada? As respostas, confirmando a sensação de acolhimento e aprendizagem que já havia sido expressa, foram mais de agradecimento por terem tido a "oportunidade" de participar do Conselho, deixando em plano secundário o espaço como um direito à defesa do direito humano à alimentação.

Obrigado! (044)

Quero falar que aprendi muito (preciso tomar cuidado se não eu choro...) eu percebi o quanto eu mudei, eu acho que participar do conselho foi fundamental para eu entender muitas coisas, acho que eu cresci muito, me libertei de bobagens, de amarras, foi uma liberdade... (045)

Para mim o conselho foi desafiante em função da faixa etária em que me encontro, novidade, e mudou toda minha vida e forma de pensar, mudou a cabeça de muito gente, experiência fantástica, um ganho pessoal e espero que a cidade venha ter um ganho também com a construção do COMUSAN. (046)

\section{Dimensão: Características e Dinâmica da Participação}

Nesta dimensão encontram-se as categorias que revelaram as características dos atores e sua identidade, localizadas no tempo e no espaço (COMUSAN-SP), suas relações e o pensamento de uns sobre os outros, evidenciando-se a percepção sobre a Administração Pública. O espaço onde se dão as relações sociais desses atores foi demonstrado através de seus atos políticos, da utilização e da abertura desse espaço.

A categoria processos é analisada a partir da organização dos trabalhos do Conselho, de sua dinâmica e dos resultados "registrados" nas falas dos grupos focais, nas falas das reuniões do COMUSAN-SP, conforme as atas e eventos avaliativos (tabela 12). 
OCOMUSAN-SP E OS PARADIGMAS DA PARTICIPAÇÃO

Tabela 12 - Dimensões e Categorias:Características e Dinâmica da Participação

\begin{tabular}{|c|c|c|}
\hline Dimensão & Categorias & Indicadores \\
\hline \multirow{3}{*}{$\begin{array}{c}\text { Características e Dinâmica da } \\
\text { Participação }\end{array}$} & a) Atores & $\begin{array}{c}\text { - Identidade } \\
\text { - Relacões Sociais } \\
\text { - Administraç̃o } \\
\end{array}$ \\
\hline & b) Espazfas & $\begin{array}{c}\text { - COMUSAN_SP } \\
\text { - Utilização } \\
\text { - Abertura }\end{array}$ \\
\hline & c) Processos & $\begin{array}{l}\text { - Organização } \\
\text { - Metodologia } \\
\end{array}$ \\
\hline
\end{tabular}

\section{a) Atores}

Os Conselheiros disseram que a Identidade do Conselho, enquanto coletivo, está em construção. Segundo eles, não há movimento de Segurança Alimentar constituido em São Paulo. Existe o Fórum Brasileiro de Segurança Alimentar (desde 1998) e está em formação o Fórum Paulista (2003). Disseram que para se considerar formada uma identidade seria necessário ter "base" de militância ativa específica no campo da Alimentação e Nutrição, assim como tem o setor Saúde. WENDHAUSEN (2002) citou o Relatório da ABRASCO de 1993, que afirmou que os Conselhos criados sob pressão dos movimentos sociais apresentam mais estabilidade e legitimidade quanto ao seu funcionamento e ainda citou outros autores que constataram que a criação "de cima para baixo" tem contribuido para que não sejam instâncias deliberativas (p. 190). ESMERALDO e SAID (2002) estudaram o Conselho Cearense de Direitos da Mulher e relataram que nos depoimentos das Conselheiras surgiram as afirmações de que as primeiras reuniões no interior do Conselho voltaram-se para a discussão sobre o significado do trabalho que pretendiam realizar, participaram de eventos, rumo a construção de um significado para o Conselho. Da mesma forma, os membros do COMUSAN-SP buscaram, na Gestão pesquisada, sua identidade, seu sentido de existir.

...Falta respaldo aos movimentos sociais que não existem especificamente neste tema (está em construção o Fórum Paulista de Segurança Alimentar e Nutricional)(066) ...Papéis sociais pouco definidos... parece campanha e não politica pública... (067) 
O COMUSAN-SP E OS PARADIGMAS DA PARTICIPAÇÃO

...Falta movimento organizado... reflexo da participação.. .muitos não aparecem na vida do Conselho... (068)

...(as entidades) aprendendo a fazer junto... (069)

... (caminhando) do individualismo para o coletivo... (070)

... qual o nosso papel? O que deliberamos sobre politicas públicas? (07I)

... estamos construindo uma identidade, agora temos um campo mais favorável para atuar fora... (072)

...enquanto coletivo...uma construção de identidade... tivemos muito mais ação como conselheiros do que como conselho, ator coletivo na sociedade, agindo na cidade... temos que pensar em criar lobs (sic) e estratégias... que nos colocasse como ator politico e estratégico na atual conjuntura, capacitando a sociedade num entendimento da Segurança Alimentar. no âmbito dos direitos humanos... (073)

O COMUSAN-SP foi instituido pela administração do Partido dos Trabalhadores que tem tradição na motivação e criação de espaços participativos como abordado por AVRITZER (2002) em seu estudo sobre o Orçamento Participativo, nas 'Experiências de Porto Alegre (1989) e Belo Horizonte (1993)'. Como meta de Plano de Governo, a Administração Municipal buscou organizar os Conselhos existentes e criar os Conselhos Setoriais onde ainda não existiam (PT 2000; SIS 2001 e CPP 2002). Apesar disso, como em todo processo de democratização do espaço público, os ritmos de concretização da participação da sociedade ocorrem de formas diferenciadas, nem sempre na velocidade esperada, pois além da influência da conjuntura essa concretização depende também de um processo histórico da área temática e dos atores participantes e sua cultura nos movimentos sociais. "O grande desafio presente nas experiências participativas é construir mecanismos capazes de minorar os efeitos das desigualdades sociais no interior dos processos deliberativos (sic), de forma a permitir que a construção dos acordos não esteja sujeita à influência de fatores endógenos como o poder, a riqueza ou as desigualdades sociais pré-existentes". (TATAGIBA 2002, p. 71).

O que os Conselheiros do COMUSAN-SP apresentaram (nas atividades de avaliação nos Grupos Focais 1 e 2) sobre a Administração, na avaliação da atuação dos membros do Governo foi o que muitos outros Conselhos perceberam em seus processos e apresentaram como problema no I Fórum de Democracia Participativa (2002), "pouco compromisso, engajamento, 
O COMUSAN-SP E OS PARADIGMAS DA PARTICIPAÇĀO

comprometimento político do governo com o processo e deliberações (proposta 16); deficiência na execução das propostas deliberadas, não ver a decisão implementada, dificuldade de transformar deliberação em ação (proposta 17) desarticulação dos órgãos públicos (p.18); dificuldade de aproximação entre gestores e população (proposta 19). TATAGIBA (2002, p. 63 e 65) ao analisar a relação de conselheiros com suas entidades também demonstrou que a representatividade dos Conselheiros governamentais é comprometida por um vinculo muito frágil entre esses e seus órgãos de origem. Tendem a defender nos Conselhos suas próprias opiniões e não as propostas e posicionamentos do Governo. Atribuiu o fato a possibilidade da pouca importância que o Estado confere à sua participação nos Conselhos, de forma geral, mandando para representá-los pessoas não preparadas para a discussão e com pouco poder de decisão. Relata que os depoimentos dos conselheiros sugerem que essa fraca relação com seus órgãos de origem tem sido empecilho à realização de suas funções e ao cumprimento dos compromissos assumidos.

A seguir, nas falas dos conselheiros sobre o pensam que da Administração Pública (Municipal, Estadual e Federal), em relação ao seu comportamento no COMUSAN-SP, detectouse falta de credibilidade no segmento governamental. Os conselheiros reclamaram da falta de entrosamento entre os diversos órgãos presentes no Conselho e da falta de poder de decisão para auxiliar no andamento e encaminhamento das questões trabalhadas. Deixaram nítida sua impressão de que o Governo não priorizou a participação da sociedade nas decisões, embora a tenha motivado.

...falta diálogo entre as secretarias... (074)

...representantes de governo não tem autonomia para representar... (075)

...falta apoio... (076)

...foi criticada... peca por estar atrelado a uma secretaria de governo... tema externamente universal e transversal... eu acho que um bom começo não é perfeito... (077)

... se não tivesse direcionamento o conselho não tinha vingado... está ai, na segunda gestão eleita... (078)

... "há limites", faltou priorizar o conselho... (079)

... dá mais importância ao fome zero, esquece que a segurança alimentar é muito mais que isso... (080)

... abismo entre essa atuação e as politicas de governo... (081) 
O COMUSAN-SP E OS PARADIGMAS DA PARTICIPAÇÃO

... o intersetorial não acontece pela dificuldade de o Conselho estar numa secretaria que não tem diálogo com as outras... (082)

A tenra existência do COMUSAN-SP já lhe impôs responsabilidades e cobranças feitas a Conselhos "maduros". "A divisão das funções entre os conselhos e as instituições administrativas e burocráticas quanto à definição, execução e acompanhamento das políticas públicas não está resolvida no âmbito da legislação pertinente. Na ausência desse marco legal e da natureza ambígua da expressão formular politicas públicas essa divisão das funções acaba ocorrendo a partir dos acordos possiveis de serem estabelecidos em cada contexto específico e em cada conjuntura particular, variando à medida que se altera o jogo de correlação de forças entre os participantes (TATAGIBA 2002, p.95)".

As falas a seguir favorecem o entendimento de uma vontade de obter resultados em curto prazo destoantes da própria avaliação dos conselheiros sobre sua atuação:

... pediu mais a colaboração do que aceitou a ação propositiva... investiu na ação segmentada... (083)

...não investiu na participação dos pares... ausência dos Ministérios... (084)

...insatisfação das iniciativas particulares... (085)

... desperdicio de espaço para discussões... (086)

... ações positivas não são de iniciativa do governo são dos conselheiros... (087)

...governo deveria trazer politicas publicas para o conselho discutir e levar para os diversos programas... (088)

... falta politica de governo definida para Segurança Alimentar e Nutricional... (089)

...falta clareza do papel de um conselho municipal... (090)

...falta vontade politica de fazer deliberativos ... demorou para reconhecer... cortou o deliberativo... (091)

... não há como priorizar programas e ações se não há vontade politica de investir no conselho... (092)

...o fato é o plano que a gente trabalha é intersetorial...ficamos localizados em uma secretaria que cria uma... a gente cria propostas. Intersetoriais e até ela sair do abastecimento e ir para a saúde, para Educação, para o meio ambiente é uma questão de 
O COMUSAN-SP E OS PARADIGMAS DA PARTICIPAÇÃO

prioridade... se estiver ligado ao gabinete da prefeitura é diferente porque promove um diálogo com as secretarias... não adianta estar em uma secretaria que o conselho não é prioridade politica... (093)

... há intenção dos técnicos (representantes do governo)contribuirem, mas há um abismo entre a part ... e as politicas de governo...(094)

... a intersetorialidade não aconteceu... dificulta... (095)

... do CONSEA (estadual)... as pessoas falam o que fazem... a gente se reúne no palácio... o governador deu posse... eu não sei nem nossos encaminhamentos... isso me incomoda...e vai me incomodar depois da Conferência... (096)

...mas não tivemos o apoio adequado do governo... (097)

... o governo deveria estar trazendo politicas publicas e discutir no COMUSAN e levar uma capacitação sobre segurança alimentar para as entidades, é um direito humano à alimentação, segurança alimentar é saúde... (098)

Ficou evidente a impaciência de vários membros do Governo em relação à sua incapacidade de decidir pelo seu órgão de origem. Como em outros Conselhos, referiu-se a estarem aprovando propostas que depois não foram executadas. Ficaram sem respaldo e sentindo-se frustrados, por acreditarem que o caminho da participação e decisão em conjunto seja o certo (MORAES 1998).

.. eu quero sair do governo para fazer alguma coisa, me sentir cidadã... é um exercício diferente... (099)

... meu papel era facilitar esse processo.. .com a experiência que eu tinha de outros conselhos... nas parcerias... em outra secretaria... uma organização diferente dessa... (100)

...como...representando o governo... minha sensação é muito parecida com todos os outros colegas... a gente não tem autonomia para atuar... representa a secretaria... de interlocutor, que leva o que aconteceu e trás muito pouco para o conselho, é mais ouvir... a gente fala... sem chão, sem dizer o que realmente acontece na secretaria... somos interlocutores naquilo que interessa... a fala não é completa... (101) 
O CONUSAN-SP E OS PARADIGMAS DA PARTICIPAÇÃO

\section{b) Espaços}

DAGNINO (2002) bem demonstrou que a construção democrática dos espaços públicos não é linear, mas contraditória e fragmentada. Além de integrarem o conjunto de forças que ocupam o poder nos vários níveis existem as estruturas estatais, autoritárias e resistentes aos impulsos participativos. A confrontação desses padrões pode ser o resultado "democratizante" esperado.

Os conselheiros visualizaram esse espaço como um canal para a sociedade discutir políticas públicas, modificar as relações entre Estado e Sociedade, romper com o paradigma dominante propiciando uma partilha efetiva de poder (DAGNINO 2002), favorecendo uma melhor condição de vida.

... tem de ser mais divulgado... para sociedade... (115)

...promover trabalho de continuidade.. (116)

... Espaço para discutir políticas publicas, o que pode ser feito, o que pode estar criando para favorecer a população (117)

... o espaço do conselho principalmente deveria ser este. pensar igual para poder em concordância levar algumas coisas avante, no caso o Conselho de Segurança Alimentar. (118)

Como tratado por DANIEL (1994, p. 22), a "democracia enquanto valor central e estratégico apresenta inúmeras decorrências. Antes de tudo, ela corresponde a efetuar várias negações [...] como o alicerce do neoliberalismo, que tem na liberdade econômica o valor dos valores: ao invés do individualismo egoísta do homem econômico, aparece o indivíduo como cidadão, aberto à articulação social com outros individuos em busca de direitos: assume-se a eficácia social e política da ação coletiva".

... o conselho não era para se fovorecer, e sim para essas entidades favorecerem uma cidade... 119

... COMUSAN... aconteceu em um momento muito bom na cidade de São Paulo, em um momento em que se estava falando de vigilância sanitária... participar do fome zero em uma cidade totalmente fecunda... pode ajudar... 120

... espaço de troca de experiência... 121 
O COMUSAN-SP E OS PARADIGMAS DA PARTICIPAÇÃO

... aqui não é espaço para ser corporativo... e u nunca traria essa discussão pra cá... 122

... antes de tudo o conselho é um espaço educativo... a gente vivencia todas as formas de educação... a gente aprende a se comportar mim espaço coletivo, aprende o outro... aprende a se relacionar... 123

Notou-se uma fusão entre a percepção que os conselheiros tem de si e do espaço quando das reivindicações de valorização, de atenção, de serem ouvidos. VALLA (2000) chama a atenção para a postura de dificuldade de aceitação de que as pessoas "humildes" sejam capazes de produzir conhecimento, organizar e sistematizar pensamentos sobre a sociedade e fazer uma interpretação que contribua para a avaliação do que estiver sendo feito. A capacidade de percepção e interpretação do que está sendo dito pela sociedade passa pela compreensão das raizes culturais, locais de moradia e a relação que seus interlocutores mantenham com os grupos que detém o poder econômico. Essas preocupações mostraram-se legitimas para a manutenção e continuidade dos trabalhos do COMUSAN-SP, dessa e de futuras Gestões.

... Conselho é reflexo do grau de prioridade dada a essa questão... 124

... aprender a falar por si... independente da secretaria... 125

... influenciou nas propostas e não executou... 126

... conselho é caixa de ressonância para as propostas da conferência... 127

... até que ponto o COMUSAN serve de referencia para as politicas publicas? 128

... Conselho teve um movimento para dentro... as pessoas... esperam um movimento para fora... 129

... modelo não é do Banco de Alimentos, Segurança Alimentar envolve vários segmentos da Sociedade. Educação. Meio Ambiente... critica-se mas não se tem iniciativa de fazer ações positivas para dar certo... 130

... mais parece campanha de fraternidade para o Fome Zero, há confusão de papéis, objetivos e propostas... mistura de papéis... 131

... tem de ser uma prioridade dos movimentos, cada um encaminhar no seu pedaço... 132

... a discussão do Fome Zero é posterior à existência do Conselho que embora se tenha dificuldades... começamos a trabalhar... a partir do nosso conselho... a criação de conselhos municipais de Segurança Alimentar e Nutricional, servimos de exemplo, mesmo 
não tendo esse trabalho efetivo do qual se fala... a gente motiva a participação das pessoas embora não organize essa participação... 133

O discurso do Conselheiro é consistente na perspectiva de reclamar a descentralização do poder, o desenvolvimento de suas atividades na participação da gestão pública, da ampliação de seu espaço, defesa de sua imagem. JACOBI (1992a), por ocasião da IX Conferência Nacional de Saúde (cujo tema principal foi a Descentralização e a Democratização do Conhecimento) em 1992, defendeu que a descentralização do poder (naquele momento do nível federal para o estadual e principalmente para o municipal) representava não só uma opção políticoadministrativa, mas também um processo de mudança qualitativa [...] que seria o maior desafio na transição brasileira o estabelecimento de novas regras de convivência entre as instâncias de poder e a população em geral, visando incrementar os mecanismos participativos e ampliando o processo de democratização do Estado, mais especificamente na administração municipal. Hoje, doze anos depois, tal defesa é pertinente e atual. Sem demora, há de ouvir-se as bases da sociedade, os conselheiros do COMUSAN-SP, através de suas representações e dividir a responsabilidade de administrar a cidade.

... motiva participação em outras instâncias... 134

... motivando a participação do Conselho no Corpo Consultivo do Banco de Alimentos... não foi para dar força... foi por que existimos... 135

... hoje cada entidade sabe por que esta no conselho... quem não sabe... na conferência (II) cai fora.. 136

... avaliar nesse momento... depois de um mandato inteiro se vale a pena continuar... se dedicar a essas ações ou não... foi um aprendizado... 137

... acho que esse conselho já tem uma história... e construida mais rápido que todos os outros conselhos... caminhamos a passos largos na estruturação do conselho... 138 
O COMUSAN-SP E OS PARADIGMAS DA PARTICIPAÇÃO

\section{c) Processos}

Os processos do Conselho foram pautados pela aprendizagem. Durante todo o tempo os conselheiros (no geral) preocuparam-se em aprender a fazer "conselho", juntos, com dedicação e entusiasmo, a despeito de ter ou não o incentivo do Governo.

A organização interna do COMUSAN-SP aconteceu em curto espaço de tempo, se comparado à organização de outros tantos conselhos que passam uma gestão inteira discutindo funcionamento (WENDHAUSEN 2002) ou aqueles que são criados por imposição legal, para repasse de verbas, e ficam discutindo a efetividade de sua existência. Embora tenha sido motivado pelo Executivo Municipal, contou com a intensa participação de instituições de todos os segmentos que o compõe para organizar a I Conferência que criou o Conselho, e, a maioria dessas instituições permaneceu, para a primeira Gestão. Esse grupo de conselheiros, que participou dessa etapa do processo, deixou escapar "pose de orgulho e de apropriação" em sua fala, ao contrário dos que se queixam de não ter acontecido "nada" (COMUSAN-SP 2002). A mola mestra de seu funcionamento é o Regimento Interno, elaborado e aprovado nos primeiros meses de atividade. A metodologia de trabalho foi a de reuniões plenárias, mensais, reuniões da comissão executiva, também mensais, reuniões em grupos de trabalho, com a freqüência imposta pelo grau de dificuldade do trabalho, avaliação anual das ações, plano de metas para organizar as proposta e calendário de atividades externas, incluindo os cursos de formação e representação em eventos de outros conselhos e instituições. $O$ que norteia todas as atividades politicas é o rol de propostas aprovadas nas Conferências Municipais de Segurança Alimentar e Nutricional de São Paulo realizadas sob coordenação do COMUSAN-SP. Sempre marcada por divisão de tarefas e participação da maioria dos membros do COMUSAN-SP, a metodologia seguida foi questionada apenas pelo setor patronal que sentiu falta de um espaço de articulação por segmento e "subsegmento" (no caso dos mesmos).

Foi possivel, ao sistematizar as principais falas dessa categoria, deduzir todo o processo de desenvolvimento das atividades, tamanho o detalhamento na descrição do mesmo.

... a estrutura fisica saiu... pressão do conselho... (139)

... regimento saiu logo... (140)

... as propostas da I Conferência foram estudadas pelos GTs... algumas foram implantadas... ... conquista do conselho... da sociedade... (141) 
... a $13^{a}$ proposta de qualidade e consumo... é o PES (Programa de Parcerias em Educação Sanitária) (141)

... o programa teve força a partir da Conferência (142)

... enquanto nascia o conselho... andava em paralelo o PES... as normas da consulta pública... eram os mesmos nas discussões... (143)

...plano de metas... fez-se uma leitura das propostas da I Conferência, balanço de 2002 e depois o plano de metas 2003... (144)

... nós estruturamos o COMUSAN, fizemos um investimento, quisemos tirar o COMUSAN do papel, demorou um tempo até chegarmos nas propostas da conferencia... (145)

... fomos protelando ação por fora... só não se desmantelou por que apareceu o Fome Zero e reviveu a expectativa... (146)

... Banco de Alimentos não andou com o Conselho... limita a ação... reflexo de não se priorizar o conselho... (147)

... tinha de ter recurso... é importante... (148)

... poderiamos ter terminado algo... não vai acontecer... as pessoas que vieram acreditando não viram as propostas... encaminhadas em ações mais direcionadas... (149) ... as mocōes que fim deram? (150)

Na reunião de setembro, foi proposto fazer mapeamento mas ... não aceitaram... naquele momento a ACELBRA falou que estava satisfeita... conseguiram tudo o que queriam... (151)

... foi mais a formação... a estrutura toda... a próxima gestão tem o papel de tornar público o conselho... levar para a sociedade.. (152)

... sozinhos (sindicatos) não conseguimos nada. mas junto com os demais, representando outros setores, teremos uma contribuição efetiva...(153)

... participar do " ciclo de formação de conselheiros" foi muito importante... (154)

... quem está achando que vai "pegar uma tarefa" vai lá fora desenvolver, não é do conselho... ele vai na entidade dele e vai discutir...(155)

... parece uma bagunça, mas um conselho é assim... (156)

... a Comissão Provisória que organizava a Conferência (I) jả chamava outras atividades para discutir coisas que estavam sendo propostas no caminho da organização 
O COMIUSAN-SP E OS PARADIGMAS DA PARTICIPAÇÃO

da conferencia. Na I Conferência muita gente colocou no papel coisas... discutidas... parcerias... normas... (157)

...e nas dezoito reuniões ordinárias que tivemos até agora e duas extraordinárias, só uma extraordinária não houve quorum... isso é inédito em uma organização de consello... (158)

...muitos conselhos deixaram de tomar decisões ou de caminhar porque não tem quorum... (159)

...muita gente justifica por ter muitos compromissos em suas entidades, não puderam vir. mas acompanharam as atas, porque está tudo lá... (160)

... a gestão interna, no entendimento de como o conselho funciona, como as pessoas se relacionam... no segundo mandato... que essas entidades todas aprenderam bastante, vão se fortalecer... na Conferência (II)... um marco... o conselho existe... o conselho enquanto coletivo chama a atenção da administração e diga que somos importantes $e$ queremos espaço político...(161)

...mudou muito depois que viemos para o gabinete. fisicamente perto, tem outro significado, tem outro peso... de apoio... o Conselho impôs que a administração desse (espaço)... isso fez a diferença.. (162)

... eu acho que o conselho impôs, mas a prioridade do governo federal fez a administração reagir de outra forma... fomos pautados de fora para dentro...(163)

...é claro que enquanto não tivéssemos a casa arrumada não poderiamos nos apresentar como ator coletivo. Tinhamos de fazer esse trabalho voltado para dentro... (164)

...o que produzimos foi esforço de sinergias... de trabalho técnico, de experiências pessoais, de trocas mútuas... agora temos de inaugurar um agenciamento para fora.. para a sociedade... (165)

...um apelo... temos de ler mais o que fizemos... nossos documentos... mesmo que não tem esse tempo... temos que saber o que foi feito... (166)

organização...

... o objetivo. do Seminário de Capacitação dos Conselhos... É sensibilizá-los para suas responsabilidades e para seu papel político, funcionamento da sociedade, participação popular, direito sanitário, decreto e nosso regimento. (Ata 6, 211) 
O COMUSAN-SP E OS PARADIGMAS DA PARTICIPAÇÃO

... os componentes das comissões são convidados a se reunirem para elaborar um cronograma de reunião. (Ata 12, 215)

... é importante que o COMUSAN se mobiliza por organizar eventos (Ata 6, 212

... lê o documento onde consta a composição do COMUSAN-SP e cita as inversões de titularidade prevista. rodizios acordado, entre as entidades na Plenária Final da Conferencia, solicita que seja incluida na pauta da proxima reunião relato. Ata 12organização 216

... precisamos motivar as pessoas a partir da II Conferencia para que possamos encontrar nossa identificação não só de direito mas também de fato, como atores importantes da Segurança Alimentar... (Ata 17, 224)

... à disposição do Conselho duas salas com toda infra estrutura necessária (Ata 14. 222) ... inclusão...

... as reuniões são abertas e que não há restrição quanto à participação de outras pessoas... (Ata 3, 207) 


\section{Dimensãa: Processas e Cultura de Participação}

As categorias desta dimensão são as Relações Sociais, os Avanços, as Transformações e as Reflexões. Tem como indicadores, nas Relações Sociais, a representatividade e a disputa; na categoria Avanços, as ações positivas e as discussões especificas de Segurança Alimentar e Nutricional; na categoria Transformações, essas dizem respeito aos conselheiros quanto a sentirem-se modificados nesse exercicio, e, na categoria Reflexões, as conjecturas do dia-a-dia, fundamentais para entender o processo como um todo.

Tabela 13 - Dimensões e Categorias: Processos e Cultura de Participação

\begin{tabular}{|c|c|c|}
\hline Dimensão & Categorias & Indicadores \\
\hline \multirow{4}{*}{$\begin{array}{l}\text { Processos e Cultura de } \\
\text { Participação }\end{array}$} & a) Relações Sociais & $\begin{array}{l}\text { - Representatividade } \\
\text { - Disputa }\end{array}$ \\
\hline & b) Avanços & $\begin{array}{l}\text { - Ações positivas } \\
\text { - Discussões especificas de } \\
\text { SAN }\end{array}$ \\
\hline & c) Transformações & \\
\hline & d) Reflexões & \\
\hline
\end{tabular}

\section{a) Relações Sociais}

As relações estabelecidas dentre a maioria dos membros do Conselho tiveram início em momentos muito positivos, os dos preparativos da I Conferência e da criação do Conselho. Sendo assim, o que normalmente acontece entre os segmentos de um conselho, como disputas e confrontos, nesse processo demorou a acontecer e se deu com maior tranqüilidade. GIACOMINI (1992) referiu-se às Conferências como sendo momentos privilegiados do debate democrático relacionado às questões do setor e suas articulações intersetoriais, fórum propício para troca de experiências, adequado para socialização de informações e bases de dados para análise dos problemas de forma mais completa. A I Conferência uniu os interessados de todos os segmentos 
O COMUSAN-SP E OS PARADIGMAS DA PARTICIPAÇÃO

no objetivo comum que era o de criar o Conselho. A $1^{\text {a }}$ gestão acontece em "ares de solidariedade".

... muita gente veio me agradecer, obrigada por você ter nos incentivado a participar (da

I Conferência) , aprendemos muito... 170

\section{Representação ou Representatividade}

A participação na forma de intervenção na vida pública referencia-se numa motivação social concreta que transparece no exercicio da representação (JACOBI 1992a), nas obrigações que foram aceitas ao se assumir esse papel social de falar pelos outros. Considerou-se a importância do modo de entrada dos conselheiros na medida em que isso se relacionou com a qualidade da representação dos diversos segmentos e com a qualidade dos resultados (WENDHAUSEN 2002). No COMUSAN-SP os membros representantes de Governo foram indicados por seus Órgãos de origem, em conformidade com o Decreto de criação do Conselho (na $1^{2}$ Gestão foi a Minuta de Decreto), os representantes dos segmentos da Sociedade Civil e Trabalhadores da Área, foram indicados pelas instituiçōes eleitas na Conferência, também obedecendo às proporções estabelecidas no Decreto Municipal.

As participações foram envolvidas em expectativas de realização de objetivos especificos (dos grupos representados) ou setoriais (ramos de atividades), no decorrer do exercício no COMUSAN-SP. O comportamento foi mudando, alguns se afastaram, mas, a maioria continuou participando e defendendo sua instituição, seu grupo social. A maioria das falas caracterizou o modo de entrada e a representação pontuando a própria ação ou fazendo observações críticas sobre a postura dos pares.

A insatisfação causada pela lentidão da realização das expectativas de cada um (a) provoca observações negativas, mas não compromete a vontade de participar. Os conselheiros prosseguem com sua freqüência normal.

... eu quis sair representante de uma outra entidade para continuar no conselho, eu me identifico mais com as questões cientificas do que com as questões trabalhistas... (168) ... sub segmentos se reúnem para discutir o tema mas não chega no conselho... (173) 
O COMIUSAN-SP E OS PARADIGMAS DA PARTICIPAÇÃO

... as pessoas vieram com outras expectativas, queriam resolver o seu lado, levar o COMUSAN para fora, de acordo com seus interesses. 179

... no geral não satisfaz, não sabe apresentar pois, falta envolvimento... 174

... como chamar agregaçöes (mais gente para as atividades) se o sentimento interno passa para outros e afasta... 175

... no coletivo, choque de culturas 176

... representantes de governo nũo tem autonomia para representar 177

... sou intermediário entre ela (Secretaria Municipal) e o COMUSAN, peço audiência para passar (os resultados) .... 178

Nem sempre há veracidade na "qualidade" da representação. Alguns conselheiros, na observação e na vivência com os demais, questionaram a real representatividade de algumas instituições. Levaram a entender que essas não têm base de sustentação, se auto-representam (os componentes da instituição não tem representado de fato).

outro problema é o da participação, normalmente uma entidade é respaldada em um movimento, em grupos sociais, não existe um movimento social de Segurança Alimentar... (180)

... o conselho tem de ser respaldado num fórum, o fórum é da sociedade civil. que está no conselho, não temos como pautar questões e fazer mobilização e levar para o conselho, isso fica entre nós (181)

... estamos plantando uma semente, há gente, organizamos nas sub prefeituras (182).

... falta respaldo nos movimentos sociais. (183)

... há carência de gente na sociedade que discuta Segurança Alimentar e Nutricional, nos coloque em evidencia e acabe fazendo essa discussão de forma mais organizada... (184)

... as entidades são assistenciais, são poucas que fazem politica de Segurança Alimentar e não aparecem no conselho, (sic) a [...], é legitima em seu trabalho e não vem a reunião...

... nunca participei de Conselho, é novidade para mim não me sinto satisfeita fico limitada.. (186) 
O COMUSAN-SP E OS PARADIGMAS DA PARTICIPAÇÃO

... não sou politica, não posso falar de política, só de sentimento. (187)

A representação também pode ser medida pela disponibilidade e dedicação aos méritos do COMUSAN-SP. O conhecimento de causa, o dominio da temática, o envolvimento com o cotidiano e as regras do Conselho não foram observados em todos os conselheiros. Alguns demonstraram falta de compromisso com a leitura dos documentos oferecidos, as atas publicadas e atenção às falas de seus interlocutores. Outros o fizeram, porém se limitaram a esse procedimento, não buscaram subsídios em suas instituições ou pesquisaram para sustentar suas intervenções.

... o que vou dizer para o CONSEA (Estadual) que estamos fazendo? (188)

... não dá para dizer que não se sabe o que é COMUSAN, tem é de se pensar a atuação.... (189)

... é uma reunião de pessoas, tudo bem que elas representam entidade, mas são pessoas. A pessoa pode ser da melhor entidade, mas se ela não se sente bem no conselho ela não vai produzir nada... 190

... eu quero sair do governo para fazer alguma coisa, me sinto cidadã, é um exercicio diferente (191)

... falta de conhecimento influi na representação (167)

... a gente vive numa cidade que faz a gente não pensar no outro... (169)

... papéis sociais pouco definidos... (17I)

... falta prioridade das entidades na indicação dos representantes, muitos nem sabem por que vieram... (172)

...representantes de governo não tem autonomia para representar... (075)

... compete ao COMUSAN a luta pela manutenção deste importante projeto que atende parte da população carente. (Ata 4, 209)

... solicita aos presente que se inscrevam para ir a... (Ata , 213)

... todos possuem o calendário das reuniões e devem ter responsabilidades para lembrar da data, saber o local as reuniões. (Ata 5, 210)

... as subprefeituras estão montando o mapa da forma da cidade de São Paulo, nosso evento deve acontecer em junho de um evento da Fome Zero (Ata 13, 220) 
O COMUSAN-SP E OS PARADIGMAS DA PARTICIPAÇÃO

... devemos ter um representante do COMUSAN-SP no CONSEA-SP (Ata 13221$)$

\section{Disputa}

As disputas no COMUSAN-SP deram-se de várias formas. Os conselheiros debateram seus pontos de vista, contestaram propostas de outros conselheiros ou ações de Governo, competiram pela representação de suas instituições, em relação ao segmento, ou do Conselho em atividades internas e externas, sustentaram posições, mesmo que conflitantes com a maioria lutaram por seus interesses da forma que lhes pareceu mais adequada e, da forma mais democrática de qualquer disputa, pelo voto.

Embora tenham sido notadas diferenças de preparo entre os conselheiros para lidar com a temática especifica, todos se expressaram de alguma forma, tendo como base de argumentação o trabalho em suas instituições. Os que não fizeram uso da palavra nas reuniões o fizeram nos grupos de trabalho e nas diversas atividades promovidas pelo conselho ou nas que este tenha participado.

Um fato singular nesse indicador foi a observação de que os representantes dos três segmentos uniram-se em alguns momentos para reivindicar do Governo, na pessoa do Presidente (Secretário do Abastecimento), o poder deliberativo do Conselho e as condições adequadas para fazer acontecer a II Conferência Municipal de Segurança Alimentar e Nutricional de São Paulo.

Seguem-se as falas dos conselheiros que embasaram essa categoria, com destaque nas palavras ou expressões mais significantes:

... precisa haver entendimento sobre as entidades de trabalhadores, sindicato, associações, conselhos, se não disputassem tanto poderiam contribuir mais com a população (192)

... "minha entidade quer isso" (193)

... tem essa briga de força, que eu acho natural por que é uma coisa nova para nós brasileiros, agente tem um referencial de cidadania ainda meio complicado, ele não é universal... (194)

... ainda tem essas brigas de forças... (195) 
... estão muito apegados a determinados movimentos e só sabem fazer aquilo por que aprenderam a fazer, daquela forma. tem essas travadas... (196)

... ainda tem embates, mas parece que se caminha para uma forma de consenso... (197)

... a criação de vários conselhos na cidade mostra que as pessoas tem as mesmas dificuldades de entendimento, de entrosamento, ainda tem disputas enraizadas oriundas de seus movimentos... (198)

... eu detesto gente que fica provocando e trapaceando o trabalho dos outros... (199)

... conflito entre os membros do COMUSAN... dificultam a contribuiçäo... (200)

... posso dizer, com base em outras vivências, que essa foi muito mais fraterna, muito mais tranqüila, as pessoas trocaram sim, dentro de suas perspectivas pessoais, aprenderam a se relacionar e a resistir... (201)

... disputa? Nem dá para prestar atenção nisso, tem é de ignorar...(202)

... protestou em relação a sua constituição (composição do COMUSAN), o enquadramento de entidades, erradamente alocados, tirando vagas de segmentos (Ata 01, 203)

... se candidatam as seguintes pessoas para constituírem a comissão... (Ata 01, 204)

... houve divergências quanto ao entendimento do objeto de reunião extraordinária (Ata $01,205)$

... protesta contra a inclusão de acesso no regimento do COMUSAN-SP, por fim aprovada a programação de inclusão do termo acesso $17 x 10$ (votos), com 03 abstenções (Ata 01. 206)

... discordo, lembrando que merenda não é projeto social e sim politica pública, sugere uma comissão, para discutir com a SEMAB este projeto social. (Ata 09, 214)

... informa que a Secretária da Saúde diz que não tem havido interação entre as varias secretarias na questão da Segurança Alimentar (Ața 17, 223)

... fizesse a leitura do texto elaborado pelos conselho, o texto foi redigido na I

Conferencia de Segurança Alimentar e Nutricional, é uma atitude impositiva suprimir o inciso sem consulta prévia. (Ata 02E, 217)

... reivindica maior apoio por parte da Prefeitura para o COMUSAN-SP... )Ata 13, 218)

... comissão para discutir com a Sra. Prefeita a alteração do Decreto do COMUSAN-SP

por lei (Ata 13, 219) 


\section{b) Avanços}

\section{Ações Positivas}

Como afirmou CORREIA (2000) o conhecimento é um processo inacabado, a cada dia o questionamento, a revisão e a ampliação. As inúmeras falas sobre as ações positivas evidenciaram um trabalho voltado para dentro preocupado com o funcionamento do conselho e com a manutenção do espaço político, com a formação dos conselheiros e seu processo de aprendizagem, buscando construir sua história e cultura de participação. Nesse processo de aprendizagem, os conselheiros ampliaram seus conhecimentos sobre Segurança Alimentar e Nutricional no sentido mais amplo, o Direito Humano a Alimentação. $\mathrm{Na}$ esfera política, a tendência é o crescimento do que chamaram de sinergia, os representantes das varias instituições (incluindo os órgãos públicos) ampliaram suas relações para alcançar seus objetivos, respaldando sua imagem pública e firmando a credibilidade de seu trabalho. Não investiram na busca pura e simples de resultados, investiram na estruturação do canal que julgaram ser o melhor para abrir portas para o diálogo Governo e Sociedade, investiram, no que disse TELLES (1994), no "fórum de negociação que pode viabilizar a construção democrática de consensos sobre as questões relevantes à vida em sociedade, sobre a verdadeira politica de Segurança Alimentar e Nutricional que é buscada. Estes consensos não eliminam conflitos e tensões, mas definem as balizas e parâmetros de agenciamento dos interesses de sujeitos diversos. E talvez, na mediação construida entre grupos e classes sociais e entre estes e o Estado, apostaram que se tenha a chance de enfrentar as dificeis relações entre pobreza e democracia (TELLES 1994, p. 52, destaques da autora)".

Abaixo, seguem os depoimentos sobre o que consideraram positivo no trabalho da $1^{\mathrm{a}}$ gestão do COMUSAN-SP:

... construçäo conjunta de 2 anos... (225)

... parcerias de entidades entre si... (226)

... núcleo da Ação (da Cidadania) em Poá (227)

... ações de algumas entidades no Butantã...(228)

... cartão de telefónica, não é mérito do conselho... (229) 
O COMUSAN-SP E OS PARADIGMAS DA PARTICIPAÇÃO

... ampliação no entendimento do conceito de Segurança Alimentar e Nutricional... (230)

... $1^{\circ}$ ano foi na estrutura, no funcionamento, no regimento não tinha legislação... (231)

... ação na educação para contribuição na sua (entidade), atuação profissional.... (232)

... conquista dos conselheiros.... (233)

... en já ouvi palestras. amigas minhas, falando do cartão (telefonico) do COMUSAN

... houve sinergia entre entidades, como no Butantã... (235)

... o conselho deu origem a uma série de palestras, foi convidado para falar, discutir conceitos, interferiu nas entidades, no dia-a-dia, são detalhes a serem registrados, o convivio dos graduandos (univ do COMUSAN) na favela fez diferença para eles, o que deixaram lá? (236)

... outras sinergias com na Vila Araguaia... (237)

... resultados que não notamos, mas são resultados, tudo isso a gente deveria mapear para mostrar... (238)

... caso da dipla cobertura do leite na Vila Albertina, nos orientamos, fizeram ação integrada com a prefeitura e o estado e deu certo... (239)

... APRAG com parceiras com outras entidades atendendo e orientando creches. gratuitamente... (240)

... o conselho ser aberto para estagiários é uma experiência importante para os cursos que são quadradinhos, ajuda a lidar com outras realidades, com o preconceito... (241)

... no $1^{\circ}$ ano nosso trabalho foi burocrático, “ de estruturamento", mas nós conhecemos... (242)

... o que foi bom com a pesquisa, foi que a gente promoveu um diálogo do equipamento com as familias... (Butantã) (243)

.. foi importante enquanto trabalho, enquanto conselho, foi contribuir para o que é Segurança Alimentar, levar para as pessoas... (244)

... a partir do COMUSAN formamos uma Comissão de Segurança Alimentar (Sindicato) e discutimos as questões dos alimentos e a questão tecnológica na produção desses. há possibilidade de fazer isso agregando todos os setores (245)

...aqui nos vamos aprender a discutir, fazer o projeto e ir para a sociedade debater. (246) 
... fazer políticas de Segurança Alimentar, mostrar que tem o Conselho... (247)

... aqui eu ganhei uma experiência fundamental para mostrar para a sociedade civil que dá para fazer alguma coisa... (248)

.. grande mérito, sair do plano da caridade para discutir o direito humano no campo do direito, isso não é pouca coisa, é no campo da cultura... (249)

... os que estavam desmotivados, conseguiram se sentir integrados e hoje já propõe a ser porta-voz.. (250)

... até as entidades que tem mais dificuldades, vão acabar se colocando, estão aprendendo... (251)

... o que aconteceu no Butantã foi tudo do conselho sim, vai irradiar para outros cantos, uma rede lá fora . (252)

... aprendi tudo, não foi? (253)

... as pessoas foram se debulhando em propostas, elas estavam ávidas em propor. (Fórum de Segurança Alimentar e Nutricional Municipal em maio de 2001), sugeriam propostas que caminharam em paralelo à criação do conselho, como o PES (Programa de Parcerias em Educação Sanitária). (254)

... a comissão provisória que foi preparar a I Conferencia, as mesmas entidades foram trabalhar nas parceiras, com outras pessoas representando, e algumas com as mesmas pessoas, trabalhando os dois processos. (255)

... ao mesmo tempo se chamou a sociedade para discutir normatização na Secretaria, na VISA (Vigilância Sanitária) de alimentos, de novo, muitas entidades tinham interesse, participaram, as três propostas caminharam juntas... (256)

... houve uma confluência de propostas, que culminaram no papel da Conferência (I)... (257) 
O CONIUSAN-SP E OS PARADIGMAS DA PARTICIPAÇÃO

\section{Discussões Especificas sobre Segurança Alimentar e Nutricional}

VILLAS BOAS (1994) tratou como fundamental o desenvolvimento de uma dimensão pedagógica das ações politico-administrativas de governo que visem possibilitar a apropriação coletiva de informações, dos mecanismos de funcionamento da gestão e desenvolvimento de uma metodologia de trabalho que torne públicas todas as mediações que incidam nas decisões sobre as politicas municipais. No COMUSAN-SP aconteceu uma mescla disso. As ações dos conselheiros foram atraindo explanações de setores do Governo, em especial da Secretaria Municipal de Abastecimento, seguida pela Secretaria Municipal de Saúde, sobre seus programas, projetos e ações administrativas que visem implementar politicas públicas de Segurança Alimentar e Nutricional, como políticas de governo.

Discutiram a temática em reuniões do Conselho, através de atividades por ele promovidas, comparecendo a eventos específicos (Conferências, Congressos, Fóruns, Seminários, Debates, Convenções, Feiras, Cursos) na qualidade de participantes, convidados, palestrantes, coordenadores, parceiros. Promoveram documentos (textos, cartilhas, manuais, folhetos explicativos, cartazes), conjuntos ou por suas próprias instituições. Marcaram presença!

Das inúmeras discussões, que podem ser lembradas também pelo conteúdo das tabelas 09 e 10, dispõe-se abaixo os registros desse indicador nas falas dos Conselheiros:

Segurança Alimentar é um tema muito novo... (062)

O Conselho foi criado antes do rumo da Segurança Alimentar ser o Fome Zero, as pessoas ainda não sabem fazer isso... (063)

Os objetivos de criar o Conselho e ter uma cultura de Segurança Alimentar dentro da Secretaria se deu de uma maneira rascunhada e começou a tomar corpo quando a gente chamou o Fórum, em maio de 2001... (064)

Temos de pensar em criar 'lobs' e estratégia, que nos colocasse como ator politico e estratégico na atual conjuntura, capacitando a sociedade no entendimento da Segurança Alimentar no âmbito dos direitos humanos, participando do debate puiblico de programas de capacitação... (065) 
A temática da Segurança Alimentar no contexto do COMUSAN-SP, pela fala dos Conselheiros, nas Reuniões, com registro em Atas publicadas em Diário Oficial do Município, justifica a existência e manutenção do Conselho como um canal legítimo de expressão da Sociedade Civil, dos Trabalhadores da Área de Segurança Alimentar e Nutricional e do próprio Governo (os setores que freqüentam o Conselho).

Os assuntos foram diversificados e de total interesse dos envolvidos:

...Regimento Interno inclui conceito de Segurança Alimentar e Nutricional, SISVAN (Sistema de Informação em Vigilância Alimentar e Nutricional), Responsável Técnico, discussão e votação... ATA 2

....Globalização (Secretario), Projetos de SEMAB.... ATA 3

...Projeto NUTRISOPA (convidado).

...Propostas da I Conferência, discussão e votação... ATA 4

...Projetos Sociais de SEMAB (incluindo Alimentação Escolar)

... Decreto Municipal 41.660/02 sobre o destino do lixo, dirigida pela Secretaria Municipal de Saúde ao Conselho (em especial os setor de supermercados) para propor parceria na execução... ATA 5

...Discussão sobre o Dia Mundial da Alimentação, campanha... ATA 6

...E da Comunidade sobre combate à desnutrição infantil... ATA 6

... Banco de Alimentos Municipal... ATA 6

... Discussão de Café da Manhã na Praça da Sé, cardápio adequado para o evento, responsabilidade, divisão de tarefas.... ATA 7

...projetos e programas da Secretaria Municipal da Saúde.... ATA 8

... Pró-Agua-Programa da Secretaria de Estado da Saúde ATA 8

... Importância Política e Ecológica da água, proposta... ATA 8

...Serviços oferecidos pela SEMAB... comvidado... ATA 9

...plano de metas 2003... proposta dos grupos... ATA 1 EX

...Plano de metas 2003... discussão e votação... ATA 10 
O COMUSAN-SP E OS PARADIGMAS DA PARTICIPAÇÃO

...avaliação do Dia Mundial da Alimentação... ATA 10

...representante para I Encontro de Conselho da Cidade de São Paulo... ATA 10

...avaliação dos trabalhos em 2002 ... grupos ATA 11

... apresentação das Subprefeituras... convidado da Secretaria de Implementação das Subprefeituras ... ATA 11

2003

... Informes do Programa Fome Zero Federal... ATA 12

... Inicio das discussões para a II Conferência Municipal... ATA 12

...Plano de Metas 2003 - GTs para execução... ATA 12

... Decreto de criação do COMUSAN-SP - $n^{\circ} 42.862$, discute o caráter deliberativo... ATA $2^{a} E$

... Projetos-de-Lei Municipais sobre Segurança Alimentar $e$ Conselhos (convidada) ATA 13

... proposta de evento para lançar plano de metas, mapa da fome (Secretaria de Assistência Social)...para divulgar imagem do COMUSAN... ATA 13

...GTs do plano de metas - relatórios... ATA 13

... moção de apoio à ACELBRA...votação ATA 14

...moção de repúdio à soja transgênica... CE... protestos... ATA 14

...GTs plano de metas...Relatórios... Fórum Interconselhos... cursos de formação... POLIS...CPP... ATA It

... GTs plano de metas...Relatórios... GT Fome zero - proposta de trabalho... proposta do COMUSAN-SP estar no Corpo Consultivo do Banco de Alimentos... ATA 15

... POSSE do COMUSAN-SP... discussão da pauta da cerimônia... ATA 15

... apresentação do projeto FISP/POLIS/ PMSP no Butantã... ATA 16

... GTs plano de metas...Relatórios... Corpo Consultivo do Banco de Alimentos... Apresentação do Fome Zero e outros projetos (convidado) ATA 17

Corpo Consultivo do Banco de Alimentos... discussão e eleição... CONSEA estadual... pauta com Secretario de SEMAB... protestos... orçamento COMUSAN... 
O COMUSAN-SP E OS PARADIGMAS DA PARTICIPAÇÃO

discussão do programa da II Conferência... GTs plano de metas...Relatórios... Comissões para II Conferência... ATA 17

... GTs (reumião, apresentação de propostas)... programação da II Conferência...apresentação e votação... plenárias para eleger delegados... organização-propostas finais das comissões... ATA 18

... discussão sobre encaminhamentos para conferência... protestos... últimos acertos... coordenação e relatórios dos grupos de trabalho na conferência... ATA 19

\section{c)Transformações}

Como os conselheiros afirmaram, não são mais os mesmos. Transformaram seu modo de pensar, de ver o mundo. Deixaram de olhar só para seus problemas e solidarizaram-se, em grande parte, com os problemas dos outros, agora parceiros, companheiros de luta por uma política de Segurança Alimentar e Nutricional no Municipio de São Paulo. Aprenderam, ensinaram, trocaram. Ampliaram seu "poder de fogo", seu poder de barganha, sua credibilidade perante os movimentos sociais. Libertaram-se, como disse um Conselheiro! Instintivamente e também aconselhados pelos mais experientes, criaram o que PONTUAL (1994) chamou de pedagogia democrática, uma intencionalidade educativa no conjunto das ações que possibilitaram apropriarse de algumas das formas de funcionamento da administração municipal e das políticas públicas da temática de Segurança Alimentar e Nutricional, apontando um novo caminho para defender e alcançar seus objetivos. Realizaram intercàmbios de "saberes" (conhecimento técnico-científico e saber popular)

As mais curiosas e interessantes expressões de transformação estão adiante:

... mudança de cultura... 258

... aprendizado... 259

...libertação... 260

...Mudei minha forma de pensar... 261

...Unir esforços... 262 
O COMUSAN-SP E OS PARADIGMAS DA PARTICIPAÇÃO

...Iniciativas conjuntas, fora do Conselho... 263

...Se o conselho não fizer, nós fazemos... 264

...Mudando do perfil de VISA para um de Segurança Alimentar.. 265

...Conquistas dos conselleiros... 266

...Mudando perfil dos conselheiros... 267

... do individualismo ... para o coletivo... 268

... balanço positivo... pessoas a ponto de desistir se seguraram e voltaram... 269

... aprendi a dar um tempo... levantar o breque... 270

\section{d) Reflexões}

Essa possibilidade de refletirem sozinhos (durante as entrevistas) ou coletivamente (nos grupos focais) foi explicitamente uma experiência impar para todos. Declararam-se, em grande parte, satisfeitos e comprometidos com a continuidade do trabalho, com o empenho para com a realização das propostas comuns às pautas das instituições.

... contribuição eu deixei, além do tempo, mas como eu posso conviver com outras pessoas, se nos não somos desejáveis, articulados... (271)

... eu participei desde o inicio, tivemos um trabalho enorme para formatar a $1^{\circ}$ Conferência, vim mais para colaborar, as dificuldades para trazer as pessoas existiu, mas de qualquer forma aconteceu, a gente nem tinha muita clareza, foi a primeira vez, mas nós aprendemos a participar, os erros que cometemos na primeira, vamos corrigindo, talvez na terceira se faça uma análise do Processo, da primeira e da segunda.... (272) Quanto ao meu trabalho, procurei passar tudo em todos os distritos, pelo meu lado profissional eu passei tudo na parte de educação mutricional. (273)

... a experiência que tive foi muito rica e passei para o secretário, por isso não me tiraram.... (274) 
... a reflexão de saber como contribuir, nas reuniões de diretoria , nossas plenárias, nos passamos o que era o conselho, não dá para dizer que não estamos fazendo nada... (275) ... se tivesse essa concepção (Segurança Alimentar e Nutricional) estaríamos apoiando a agro industria familiar e outras iniciativas... (276)

... conto chinês, do Bambu, que se rega durante sete anos, rega, rega e não vê nada, mas depois de sete anos, aparece uma floresta. por que ele criou, naqueles sete anos, raizes. Temos de regar a mudança cultural nesse pais, assim é a cultura da participação, parece que não tem nada. mas tem... (277)

... muita gente dos movimentos foi trabalhar no Governo, isso não foi percebido, mas estão ai! (278)

... existe uma ansiedade das pessoas em dar idéias alem de fazer avaliação.. (279)

... alguns setores tem dificuldade de lidar com questões do conselho não sabem o que fazer... (280)

... muitos estão aqui não para participar do conselho mas para obter vantagens...(281)

... os que não tinham acesso a movimentos sociai..., movimentos comunitários, trabalhadores e o governo, na maioria, não conheciamos nada, isso foi aprendizagem... (282)

... numa cidade deste tamanho não dá para achar que em cinco minutos vai resolver um problema.. (283)

... tudo bem que nascemos numa instância governamental, mas temos de sair desse berço, temos de caminhar sozinhos. o conselho tem de falar por ele mesmo. fazer seu marketing. 284

... tem uma coisa nova acontecendo em cada conselho da cidade... (285)

... até as entidades que tem mais dificuldade em se colocar vão acabar se colocando, estão aprendendo a fazer isso... (286)

... ainda não tive a oportunidade de fazer essa avaliação de forma critica, ela tem sido fragmentada dos diversos momentos... (287)

... histórias se cruzam, foi fruto do conselho, produto de trabalho dos conselheiros, grande triunfo dessa $1^{\circ}$ gestão... (288)

... uma história não se construiu de um dia para o outro, meu papel era de facilitar, não de dizer como deveria ser feito, a conferência traçou os objetivos do conselho quando criou a mimuta do decreto... (289) 
O COMUSAN-SP E OS PARADIGMAS DA PARTICIPAÇÃO

... a participação é indelével, ela sabe, ela ouve, ela acumula documentos, oportunidades no trajeto vai formando opiniões e a partir da sua vivência sabe porque o conselho foi constituido, por que ela está aqui... (290)

... reuniões ordinárias, extraordinárias, só uma extraordinária não teve quorum, isso é inédito numa organização de conselho... (291)

... não dá para falar que essa participação foi efetiva enquanto governo, dentro do Conselho. "preconceito" antigo da história da administração pública que tem combatido. defendido que governo tem de ser aberto, ouvir a sociedade, os trabalhadores... (292)

... acho que a conferência (29) tem esse papel, fazer virar em valor a existência do Conselho, acho que foi uma via de contramão, o desmantelamento da SEMAB quanto houve o lançamento do FOME ZERO, tiveram de puxar o breque...(293)

... como iriam justificar que a maior cidade do pais. que tinha um conselho estava desestruturando a Segurança Alimentar?(294) 


\section{6- CONCLLUSÃO}

Para os Conselheiros do COMUSAN-SP, dos segmentos Sociedade Civil e Trabalhadores, o significado de participação correspondeu aos paradigmas apresentados no referencial teórico, a partir de suas proprias experiências, de exercicio de um papel social (com representações sociais, incompletas e inacabadas) que deu conta de sua representação politica, com autonomia. Dispostos a assumir o princípio da responsabilidade e co-responsabilidade através da problematização do conhecimento científico somado ao saber popular e ampliado para uma visão sistêmica de vida. Esse conjunto, "credenciado" por suas bases (sendo remunerados ou voluntários, não importa), formula o senso comum participativo.

O Governo, embora no discurso apregoe a participação segundo o paradigma emergente, ainda utiliza métodos do paradigma dominante, confundindo participação (dimensão política) com solidariedade (dimensão ética). Deixando de discutir Desigualdade Social versus Capitalismo, pela análise das condições sociais e dos modelos culturais, do conhecimento retrospectivo (considerando, por exemplo, o cenário da fome no pais, aproveitando o contexto do Programa Fome Zero) para caminhar para um futuro de propostas e ação.

Perdeu-se muito tempo, temendo a revalorização e reinvenção do conhecimento emancipatório, por conta das disputas, muitas vezes simuladas, e da dificuldade da "partilha do poder de decisão" (TATAGIBA 2002).

Embora esse quadro pareça preocupante para os rumos do COMUSAN-SP, a maioria de seus membros, se não todos, incluindo os representantes de governo (que se julgam apenas interlocutores no processo) conjugam a idéia de que a iniciativa foi positiva, se trabalhou muito e que há de se utilizar de outras estratégias como a Intersubjetividade, fazendo com que todos exponham seus objetivos e na transparência dos mesmos busquem consensos; com concepções holisticas, elevando a Segurança Alimentar e Nutricional ao patamar do Direito Humano à Alimentação, com nova estrutura conceitual para economia e tecnologia, mesmo que haja "arestas a aparar" em relação aos conflitos de interesses demonstrados em seu percurso. 
O COMUSAN-SP teve um dos mais ricos processos de instalação e primeira gestão que se tem conhecimento. Conseguiu se organizar e se estruturar em curto espaço de tempo, proporcionou cursos de formação para grande parte de seus conselheiros, tendo em vista que esses não tinham experiência de atuação em Conselho e deleitaram-se com as "lições de cidadania". Como nenhum processo de "alicerce" aparece para a "mídia" com resultados apurados podem não ter vulto para fora (os expectadores), mas, internamente, com certeza farão diferença para o exercicio político da $2^{\mathrm{a}}$ Gestão. Constituiu-se num espaço de democratização de informações e preparou-se para reivindicar, com força, o exercicio do poder. Soube conquistar espaço junto aos demais Conselhos Municipais e terá eco quando levar suas questões para a sociedade. As deliberações pendentes em execução poderão ser facilmente cobradas, devido a imagem que criou e aos "holofotes" que terá condições de ascender para demonstrar a importância devida às suas preocupações. A partir do trabalho da $1^{a}$ Gestão, organizado, estruturado e consistente, a $2^{a}$ Gestão terá possibilidade de tecer estratégias de ação para o plano de metas e para todas as propostas das duas Conferências realizadas. O poder deliberativo que tanto se reclamou, principalmente em sua $1^{\text {a }}$ reunião extraordinária, a decepção de não ter tido 0 artigo correspondente incluso no Decreto de criação e a passageira "desmotivação" de alguns membros ficarão na lembrança quando conseguirem, pelas sementes que plantaram, mobilizar a população que representam e fazer a devida pressão para concretizar a realização de seus projetos.

Finalmente é possivel afirmar que apesar de todos os estigmas dos paradigmas dominantes para a participação, os membros do COMUSAN-SP estão "remando a favor da maré" e conseguindo acelerar o processo de transição para o paradigma emergente, a participação de fato, a da partilha do poder, a de discutir e decidir os rumos políticos da Segurança Alimentar e Nutricional no Municipio de São Paulo.

Suas perspectivas não são únicas, dadas as diversidades de sua formação e constituição, mas convergem para o anseio de fazer "dar certo" e produzir politicas públicas para a Segurança Alimentar e Nutricional, apontando caminhos para uma existência digna, enquanto Conselho, representativa de direito e "de fato", com nuances ecológicas, feministas, anti-racistas, e outras que se apresentarem na trajetória dessa luta "prazerosamente" travada como "aprendizagem" de vida, para vidas tão cheias de esperanças. Realmente pensam que as transformações não se esgotam nas contradições, mas também na somatória de esforços, na cumplicidade, na intersetorialidade, na mudança de atitudes, na "reinvenção do senso comum". 
A interação (relacionamento) entre os segmentos não foi a esperada, pois almejavam que o governo dividisse o espaço eqüitativamente e contribuísse para a eqüidade da participação entre os segmentos, o que não aconteceu por completo. Mesmo assim, julgaram que o saldo é positivo na sua avaliação. "Valeu a convivência", o aprendizado:

“...o que produzimos foi esforço de sinergias... de trabalho técnico, de experiências pessoais, de trocas mútuas... agora temos de inaugurar um agenciamento para fora... para a sociedade..." (conselheira da Sociedade Civil)

... a gestão interna, no entendimento de como o conselho funciona, como as pessoas se relacionam... no segundo mandato... que essas entidades todas aprenderam bastante, vão se fortalecer... na Conferência (II)... um marco... o conselho existe... o conselho enquanto coletivo chama a atenção da administração e diga que somos importantes e queremos espaço politico...(conselheira de Trabalhadores da Área)

... tem essa briga de força, que eu acho natural por que é uma coisa nova para nós brasileiros, agente tem um referencial de cidadania ainda meio complicado, ele não é universal... (conselheira de governo)

Foi importante, conforme a fala dos conselheiros, a participação em outros canais institucionais, na cidade de São Paulo, como o Fórum Interconselhos, promovido pela Coordenadoria de Participação Popular. Saber que outros conselhos têm problemas semelhantes aos do COMUSAN-SP foi confortante no sentido de entender que a história se faz em ritmo mais lento que o esperado, mas há que se conseguir, num esforço comum, sensibilizar a Administração Pública para reconsiderar seus encaminhamentos e cumprir suas próprias "defesas": a participação ativa da sociedade nos canais institucionais, com poder deliberativo. 
O COMUISAN-SP E OS PARADIGMAS DA PARTICIPAÇÃO

\section{7 - CONSIDERAÇÕES FINAIS}

Constatou-se que as práticas no COMUSAN-SP refletiram sobre as condições de funcionamento, as ações, as relações sociais e em especial, nas relações de poder ali encontradas. Demonstraram as diversidades de pensamento e os niveis de conhecimento dos conselheiros.

A relação entre o que foi proposto pela Administração Pública, o que está no papel (decreto) e o que realmente aconteceu, demandou conflitos inesperados, se considerado o paradigma emergente (SANTOS BS 2000).

Sem dúvida existe o espaço de diálogo, por vezes "mudo", mas, existe. Os conselheiros não abriram mão, em sua avaliação, de dizer que a criação do COMUSAN-SP foi um avanço, que se produziu aprendizagem em larga escala e convívio prazeroso.

Suas reflexões apontaram para a continuidade do processo, inclusive com seu próprio empenho em que o COMUSAN-SP se torne "autônomo" e mais independente dos laços governamentais.

Acreditou-se que o trabalho realizado pelo conjunto dos conselheiros, independente do segmento, produziu uma esfera especial de poder, comunicação e aprendizado (como os próprios tanto enfatizaram), que aguçou para uma atuação especifica e potencialmente bem sucedida no combate à fome e à miséria.

Por solicitação dos conselheiros, no decorrer das entrevistas, ponderaram-se também desafios para a $2^{\mathrm{a}}$ Gestão, para a qual muitos foram reeleitos, quanto à continuidade do trabalho, a mudança de estratégias e o desenvolvimento da cultura participativa, história em curso, com recomendações que julgam importantes, sistematizadas na tabela 14 . 
Tabela 14: FALA DOS CONSELHEIROS PARA 2a GESTÃO

\begin{tabular}{|c|c|c|}
\hline DESAFIO & RECOMENDAÇÃO & AÇÃO \\
\hline $\begin{array}{c}\text { Combate á fome e promoção da } \\
\text { Segurança Alimentar }\end{array}$ & $\begin{array}{l}\text { - Trabalhar o Direito Humano à Alimentação } \\
\text { - Esclarecimentos sobre as ações do Fome Zero } \\
\text { e desmistificar o caráter de solidariedade } \\
\text { - Incentivar o consumo de alimentos orgânicos } \\
\text { - Discutir transgênicos } \\
\text { - Combater o desperdício da água }\end{array}$ & $\begin{array}{l}\text { Participar efetivamente do } \\
\text { Corpo Consultivo do Banco }\end{array}$ \\
\hline $\begin{array}{c}\text { Curso de Formação para } \\
\text { Consellyeiros }\end{array}$ & $\begin{array}{l}\text { - Iniciar a gestäo com um curso rápido para quem } \\
\text { quiser e fazer na sequiência outsos, até cobrir a todos } \\
\text { - Fazer integração entre os antigos eos novos }\end{array}$ & $\begin{array}{l}\text { Participar do Fórum } \\
\text { Interconsellios e Fórum } \\
\text { Pazulista de SAN }\end{array}$ \\
\hline $\begin{array}{l}\text { Influenciar nas políticas } \\
\text { públicas }\end{array}$ & $\begin{array}{l}\text { - Discutir as políticas públicas da área de SAN e } \\
\text { adaptá-las à nossas realidades } \\
\text { - Participar dos CONSEA-Estadual e Nacional com } \\
\text { posições, documentos }\end{array}$ & $\begin{array}{l}\text { Fazer aparições públicas } \\
\text { enquanto COMUSAN-SP }\end{array}$ \\
\hline $\begin{array}{l}\text { Influenciar nas poífíticas do } \\
\text { governo }\end{array}$ & $\begin{array}{l}\text { - Forçar o governo a điscutir quais propostas conosco, } \\
\text { fazer proposta sobre programas e mudanças } \\
\text { necessárias }\end{array}$ & $\begin{array}{l}\text { Fazer manifestos } r \\
\text { manifestaçðes }\end{array}$ \\
\hline Acesso à informação & $\begin{array}{l}\text { - Veicular documentos e legisfações } \\
\text { - Reproduzir materiais } \\
\text { - Ter a Política Nacional de Segurança Alímentar e } \\
\text { Nutricional e seus desdobramentos Programas } \\
\text { - Cademo do conselheiro }\end{array}$ & $\begin{array}{l}\text { Fazer Boletim Informativo do } \\
\text { COMUSAN-SP }\end{array}$ \\
\hline Trocar de Experiências & $\begin{array}{l}\text { - Fazer apresentações das entidades nas reuniões, } \\
\text { - espaço garantido para expor trabalhos } \\
\text { - Reproduzir materiais das entidades } \\
\text { - Trocar informações das entidades }\end{array}$ & $\begin{array}{l}\text { Promover sinergias } \\
\text { Ações conjuntas } \\
\text { Parcerias }\end{array}$ \\
\hline $\begin{array}{l}\text { Produzir Indicadores para açōes } \\
\text { políticas do COMUSAN }\end{array}$ & $\begin{array}{c}\text { - Mapa da Fome por Região } \\
\text { - Mapa da Desnutriçăo / Obesidade } \\
\text { - Levantamento das entidades que tem parcerias com } \\
\text { a PMSP (geral) }\end{array}$ & $\begin{array}{l}\text { Obter o Mapa da Fome } \\
\text { (SAS/SIS) } \\
\text { Mapas das Entidades }\end{array}$ \\
\hline
\end{tabular}


O COMUSAN-SP E OS PARADIGMAS DA PARTICIPAÇÃO

\section{8-REFERÊNCLAS}

AUTOR ponto Título da parte ponto In dois pontos Autor da publ (ou editor) ponto Tít da publ ponto Edição ponto Local (cidade) dois pontos Editora ponto e vírg ano ponto paginação ponto

AMMAN SB. Participação Social. São Paulo: Cortez \& Moraes LTDA; 1977.

AVRITZER LO. O Orçamento Participativo: As experiências de Porto Alegre e Belo Horizonte. In: DAGNINO E (org.), Sociedade Civil e Espaços Públicos no Brasil. São Paulo: Paz e Terra; 2002.

BARDIN L. Análise de Conteúdo, Lisboa: Edições 70; 1977.

BENEVIDES MV. Democracia e Cidadania. In: VILLAS-BOAS R. org. Participação Popular nos Governos Locais, PÓLIS, Instituto de Estudos, Formação e Assessoria em Politicas Sociais, São Paulo, 1994

BOFF L. Saber Cuidar. Rio de Janeiro: Vozes; 1999.

CALDERÓN AI. Democracia Local e participacão popular: a Lei Orgânica paulistana e os novos mecanismos de participação popular em questão. São Paulo: Cortez; 2000.

CAPRA F. O Ponto de Mutação. São Paulo: Ed. Cultrix; 1982.

CARVALHO AI. e col. Os Caminhos da Descentralização no Setor Saúde Brasileiro. Rev. Saúde em Debate. Londrina. 1993; nº 38.

CARVALHO MCAA. Participação Social no Brasil Hoje. PÓLIS PAPERS. São Paulo. 1998. $\mathrm{n}^{\circ}$ 2. [Acessado em 13 de fevereiro de 2001. Disponivel em http://www.polis.org.br/publicacoes/papers/19982.html]

CASTRO AM e col. Breves Comentários sobre Fome e Segurança Alimentar. [acessado 29/10/2003disponivel em http://www4.prossiga.br/fome/seguranca.html]

CNBB. Setor Pastoral Social. A Prática da Cidadania como Educação Política. Rio de Janeiro: Vozes; 1996. 
O COMUSAN-SP E OS PARADIGMAS DA PARTICIPAÇÃO

COMUSAN-SP. Conselho Municipal de Segurança Alimentar e Nutricional de São Paulo, Secretaria Municipal de Abastecimento. Relatórios, Oficios, Balanços de Gestão, Atas. São Paulo: SEMAB/PMSP; periodo de 2001 a 2003

BRASIL. CONSTITUICÃO DA REPÜBLICA FEDERATIVA DO BRASIL. São Paulo: IMESP; 1988.

CORREIA MVC. Que Controle Social? Os Conselhos de Saúde como Instrumento, Rio de Janeiro: FIOCRUZ; 2000.

CPP - CORDENADORIA DE PARTICIPAÇÃO POPULAR. Informativo Interconselhos. São Paulo: PMSP/SGM; 2003. Ano I nº1.

DAGNINO E. (org.), Sociedade Civil e Espaços Públicos no Brasil, São Paulo: Paz e Terra; 2002.

DANIEL C. Gestão Local e Participação da Sociedade. In: VILLAS-BOAS R. Participação Popular nos Governos Locais. São Paulo: POLIS; 1994. N¹4.

DEMO P. Elementos Metodológicos da Pesquisa Participante. In: BRANDÃO, Carlos Rodrigues. org. Repensando a Pesquisa Participante. São Paulo: Brasiliense; 1999.

SÃO PAULO. DOM Diário Oficial do Municipio de São Paulo. Comunicados, Decretos e Leis. IMESP; maio de 2001 a outubro de 2003.

ESMERALDO GGSL. e SAID MA. O Conselho cearense de direitos da Mulher - CCDM espaço de interlocução entre as demandas dos movimentos de mulheres e o estado, in DAGNINO E. org. Sociedade Civil e Espaços Públicos no Brasil. São Paulo: Paz e Terra; 2002.

FALCÃO R. Reconstruindo com Participação Popular in CPP. Informativo Interconselhos, São Paulo: PMSP; 2003. Ano I, No1.

FAO Organização das Nações Unidas para a Alimentação e Agricultura. Alimentação para todos. Portugal: Conteudo; 1996. 
OCOMUSAN-SP E OS PARADIGMAS DA PARTICIPAÇĀO

FAO. Organização das Nações Unidas para a Alimentação e Agricultura. Cúpula Mundial da Alimentação, Declaração fr Roma sobre a Segurança Alimentar Mundial \& Plano de Ação da Cúpula Mundial da Alimentação. Biblioteca Virtual de Direitos Humanos da Universidade de São Paulo: Comissão de Direitos Humanos; 2003. [Disponivel em www.direitoshumanos.usp.br/atualizado em 10/04/03].

FASE Federação de Órgãos para Assistência Social e Educacional. Análise de Estrutura e Conjuntura série "como fazer", s.n.t.

FIONG Fórum Internacional de ONGs e Movimentos Sociais. Tratado das ONGs. Rio de Janeiro: Instituto de Ecologia e Desenvolvimento; 1992.

FREIRE P. Extensão ou Comunicação. Rio de Janeiro: Paz e Terra; 1992.

FREIRE P. Pedagogia da Autonomia. São Paulo: Paz e Terra; 2000.

GIACOMINI C H. A Sociedade Civil e a Garantia do Processo de Reforma Sanitária. Cadernos da Nona. Brasília: IX CNS, 1992. № 1.

GRACIANO PG e ARZABE PHM. A Declaração Universal dos Direitos Humanos, In: Centro de Estudos da Procuradoria Geral do Estado. Direitos Humanos: Construção da Liberdade e da Igualdade, São Paulo: Centro de Estudos da Procuradoria Geral do Estado; 1998.

\section{FÓRUM SOBRE DEMOCRACIA PARTICIPATIVA, Construindo Metodologias de}

Participação e Deliberação Pública: As Experiências de Barcelona e São Paulo. São Paulo: 04 e 05 de julho de 2002. [Disponivel em http://www.delibera.info/pub/projectes/FDPsaopaulo/home.htm acessado em 19/01/2003 e 23/08/2003]

IBGE Instituto Brasileiro de Geografia e Estatística. Populacão Estimada para 2001. São Paulo Municipio. [Disponivel em http://www.ibge.gov.br/acessado em 01/07/2002 e 01/08/2003]. 
O CONUSAN-SP E OS PARADIGMAS DA PARTICIPAÇÃO

JACOBI P. Descentralização Municipal e a Participação dos Cidadãos: Apontamento para o Debate. CNS. Cadernos da Nona. Brasilia: IX CNS, 1992a. nº 1.

JACOBI P. Participação e Gerência dos Serviços de Saúde: desafios e limites no município de São Paulo. Revista de Administração Pública. Rio de Janeiro: abr-jun 1992b.

KAYANO J e CALDAS E L. Indicadores para o Diálogo. PÓLIS, Programa Gestão Pública e Cidadania. EAESP/FGV. São Paulo: POLIS; 2001.

KUHN TS. A Estrutura das Revoluções Cientificas. São Paulo: Perspectiva; 2003.

LAROUSSE CULTURAL. Dicionário da Lingua Portuguesa. São Paulo: Editora Universo; 1992.

LEAL RLM. Ações de Saúde num Sindicato de Servidores Municipais. São Paulo; 1999a. [dissertação de mestrado - Faculdade de Saúde Pública da Universidade de São Paulo]

LEAL RLM. Educação em Saúde como um Caminho para o Exercicio Pleno da Cidadania. In: Congresso Brasileiro de Ciências Sociais e Saúde. São Paulo: 1999. Rio de Janeiro: ABRASCO; $1999 b$.

LEFĖVRE F. Promoção de Saúde, Informação e Tomada de Decisão. São Paulo: FSP/USP; 2002 .

SÃO PAULO. LEI ORGÂNICA DO MUNICÍPIO DE SÃO PAULO, IMESP; 1990.

LEVCOVITZ E e col. Políticas de Saúde nos Anos 90: Relacões Intergovernamentais e o Papel das Normas Operacionais Básicas. Revista Ciência e Saúde Coletiva. Rio de Janeiro: ABRASCO; 2001. Vol 6, n 2 .

LYRA R P. Os Conselhos de Direitos do Homem e do Cidadão e a Democracia Participativa, [disponivel em http://www.dhnet.org.br/w3/ceddhc/ceddhc/rubens2.htm, acessado em 18/08/2002].

MARX K. O Capital - O Processo de Produção, 11. São Paulo: Ed. DIFEL; 1987. Cap. I e V vol. 1, livro I 
O COMUSAN-SP E OS PARADIGMAS DA PARTICIPAÇÃO

MENDES EL. Parâmetros para análise de propostas ou experiências com orçamento participativo. PUC/SP São Paulo: ENANPAD; 1996.

MENDES ELV. Uma Agenda para Saúde. 2a. São Paulo: Hucitec; 1999.

MINAYO MCS. Pesquisa Social. Rio de Janeiro: Vozes; 1993.

MINAYO MCS. O Desafio do Conhecimento, Pesquisa Qualitativa em Saúde. $3^{\text {a }}$. São Paulo e Rio de Janeiro: Hucitec-ABRASCO; 1994.

MS Ministério da Saúde. Caderno de Promoção da Saúde - Carta de Ottawa, Declarações de Adelaide, Sundsvall, Bogotá, 1996 e Jacarta. 1997 tradução: Luís Eduardo Fonseca. Brasília: MS; 2001.

MORAES CV. A Participação Popular na Gestão das Políticas para a Infância e Adolescência em Santa Catarina. [Dissertação de Mestrado - UFSC. Santa Catarina: 1998].

OPAS Organización Panamericana de la Salud. La participación Social. Serie Desarrollo y Fortalecimiento de los Sistemas Locales de Salud. HSD/SILOS-3. Washington: OPS; septiembre 1990.

OPAS/OMS, Desarrollo y forlalecimiento de los sistemas locales, La Participaion Social en el desarrollo de la salud, HSS/SILOS-26, Washington: OPS; 1993.

PELICIONI MCF. Educação em Saúde e Educação Ambiental: Estratégias de Construção da Escola Promotora de Saúde. São Paulo: 2000. [Tese de Livre Docência - FSP/USP]

PONTUAL P. Por uma pedagogia da participação popular.In: VILLAS-BOAS R. Participação Popular nos Governos Locais. São Paulo: POLIS; 1994. No14.

PT Partido dos Trabalhadores. Plano de Governo para o Município de São Paulo. São Paulo: PT; 2000.

QUEIROZ MIP. Variações sobre a Técnica de Gravador no Registro da Informação Viva, São Paulo: CERU e FFLCH/USP; 1983. 
O COMUSAN-SP E OS PARADIGMAS DA PARTICIPAÇÃO

REIGOTA M. Ecologia, Elites e Intelligentsia na América Latina: Um Estudo de suas Representações Sociais. São Paulo: Annablume; 1999.

RODRIGUES AT. Ciclos de mobilização política e mudança institucional no Brasil, Universidade Federal do Espirito Santo [acessado em 18/08/2002, disponivel em http:/www.politica.pro.br].

ROZENFELD S e COSTA E A. Constituição da Vigilância Sanitária no Brasil. In:

ROZENFELD S. org. Fundamentos da Vigilância Sanitária. Rio de Janeiro: FIOCRUZ; 2000.

SANTOS JR. AO. Democracia e Governo Local: dilemas da Reforma Municipal no Brasil. Rio de Janeiro Revan / FASE; 2001

SANTOS BS. A Crítica da Razão Indolente: Contra o desperdício da experiência, São Paulo: Cortez Editora; 2000.

SANTOS M. Por Uma Outra Globalização, do pensamento único à consciência universal, Rio de Janeiro: Record; 2000.

SEMAB Secretaria Municipal de Abastecimento. FOME, O Desafio dos Anos 90, Anais do Seminário Nacional de Abastecimento. São Paulo: SEMAB; 16 a 19 de outubro de 1990

SEMAB Secretaria Municipal de Abastecimento, Departamento de Inspeção Municipal de Alimentos. Relatórios, Oficios, Balanços de Gestão, Atas do Conselho Municipal de Segurança Alimentar e Nutricional de São Paulo, São Paulo: SEMAB/PMSP; 2001 a 2003.

SECRETARIA MUNICIPAL DE PLANEJAMENTO URBANO, Plano Diretor Estratégico do Município de São Paulo. São Paulo: PMSP; 2002.

SILVA CM. Participação Popular: Conceitos, Condicionantes e o Papel do Estado na sua Concretização, Faculdade de Economia, Administração e Contabilidade [monografia Universidade de São Paulo, disponivel em http://www.fea.usp.br/fia/reforma/Producao.htm, acessado em 18/08/2002].

SIS Secretaria de Implementação das Subprefeituras. Plano Diretor da Cidade de São Paulo, São Paulo: PMSP; 2001. versão preliminar. 
O COMUSAN-SP E OS PARADIGMAS DA PARTICIPAÇÃO

SPINK MJP. A Construção Social do Saber sobre a Saúde e Doença: Uma Perspectiva

Psicossocial. In: Saúde e Sociedade. São Paulo: FSP/USP; 1992. 1(2), p. 125-139.

TANAKA OY. e MELO C. Avaliação de Programas de Saúde do Adolescente, um Modo de Fazer. São Paulo: EDUSP; 2001.

TATAGIBA L. Os conselhos gestores e a democratização das políticas públicas no Brasil, in DAGNINO E. org. Sociedade Civil e Espaços Públicos no Brasil, São Paulo: Paz e Terra; 2002.

TELLES V. Sociedade Civil, Direitos e Espaços Públicos, In:VILLAS-BOAS R. Participação Popular nos Governos Locais. São Paulo: POLIS; 1994. N¹4.

TOURAINE A. Palavra e Sangue: Política e Sociedade na América Latina. Campinas:

UNICAMP/Trajetória Cultural; 1989.

TOURAINE A. Método da Sociologia de Ação, Intervenção Sociológica - Revista Novos Estudos. 1992. n. ${ }^{\circ}$,

TRINDADE JDL. Anotações sobre a História Social dos Direitos Humanos, In: Centro de Estudos da Procuradoria Geral do Estado. Direitos Humanos: Construção da Liberdade e da Igualdade. São Paulo: Centro de Estudos da Procuradoria Geral do Estado; 1998.

VALLA VV. Procurando Compreender a Fala das Classes Populares, in VALLA VV. org. Saúde e Educação. Rio de Janeiro: DP\&A; 2000.

VASCONCELOS EM. Educação Popular e a Atenção à Saúde da Familia. São Paulo: Hucitec; 1999.

VILLAS-BOAS R. org. Participação Popular nos Governos Locais. São Paulo: PÓLIS; 1994

VILLAS BOAS R. Os canais institucionais de participação popular, In: VILLAS-BOAS R. org. Participação Popular nos Governos Locais. São Paulo: PÓLIS; 1994

WEFFORT FC. Qual democracia? São Paulo: Cia. das Letras; 1992.

WENDHAUSEN A. O duplo sentido co controle social, Itajai: UNIVALI; 2002. 
ANEXOS 


\section{Anexo 01}

\section{FÓRUM SOBRE DEMOCRACIA PARTICIPATIVA}

Construindo Metodologias de Participação e Deliberação Pública: As Experiências de Barcelona e São Paulo

O I Fórum sobre Democracia Participativa foi realizado em São Paulo, nos dias 4 e 5 de julho, e reuniu 180 pessoas envolvidas em diversos projetos de participação popular da Prefeitura de São Paulo para discutir como melhorar a qualidade destes processos participativos. Foi realizado pela Coordenadoria Especial do Orçamento Participativo (COP), Projeto Democracia Participativa (Universidade Federal de Minas Gerais - UFMG) e Coordenadoria de Participação Popular (CPP) numa parceria entre o Município de Barcelona (Serviço de Participación Interactiva - SPI) e o Município de São Paulo para troca de experiências sobre participação, tendo como convidados representantes do Orçamento Participativo, das várias regiões da cidade de São Paulo e membros de Conselhos Municipais interessados. O Fórum contou com a contribuição de técnico espanhol que demonstrou a aplicação do método participativo Delibera.Info, Sistema Integral de Participació (aplicado pelo Conselho Municipal de Meio Ambiente e Sustentabilidade na Agenda 21 de Barcelona)

\section{Resultados do I Fórum sobre Democracia Participativa (São Paulo) \\ 1. Problemas sobre Participação no Fórum Sao Paulo.}

Lista dos principais problemas elencados e priorizados por cerca de 120 participantes nos subgrupos do Fórum. Indique dentre estes os que the parecem ser os problemas mais relevantes que você encontra na sua experiência de participa popular, especialmente em São Paulo.

1. Mal funcionamento da logística - estruturas e organização do processo

2.A divulgação está fraca - comunicação deficitária dos processos e reuniões

3. Há uma falta de acessibilidade ao processo participativo

4. Falta de clareza/explicação e democracia nas regras "do jogo" 
5. Falta de planejamento (na mobilização e execução)

6. Confusão das lideranças e população sobre os objetivos, falta de esclarecimento e falsas expectativas.

7. Falta de capacitação dos agentes de execução / baixa qualificação técnica

8. Falta de eficácia de concretude e objetividade nas reuniðes

9. Indisciplina, desorganização / diálogos de surdos nas reuniões

10. Metodologias das reunið̌es e capacitação dos moderadores inadequada

11. Deficiência na metodologia das assembléias / falta de metodologia participativa

12. Falta de Cultura de Participação \& descrédito no processo participativo

13. Interesses implícitos determinando o processo comum / predomínio de interesses alheios à coletividade / grupos organizadc $\mathrm{X}$ não organizados

14. Nao inclusão dos ditos minoritários (gênero, raça, idade, deficiência, gays...)

15. Questōes de cidadania / contexto de competição

16. Pouco compromisso/engajamento/comprometimento político do governo com o processo e deliberaçães

17. Deficiência na execução das propostas deliberadas / não ver a decisão implementada / Dificuldade de transformar deliberaçã em ação

18. Desarticulação dos órgaos públicos

19. Dificuldade de aproximação entre gestores e população

20. Questoes éticas na condução do processo

21. Não acompanhamento/monitoramento de todas as etapas do processo

22. Deficiência do diagnóstico das prioridades eleitas pela população

23. Centralização do poder (monopólio da informação, conhecimento..)

24. Nem todos têm garantia de expressão/ excesso de direcionamento

Leque de valoraçôes que contempla 3 valoraçôes realizadas (até a data: 12/09/2002 12:25) sobre o texto

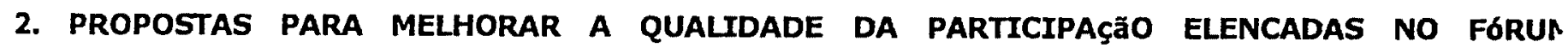
Se quizer ver os comentários sobre um artigo determinado, clique no correspondiente 8 Adequação do ambiente da reunião...

6 Comunicação articulada e multiplicadora (explicar bem local e forma da reunião)/Esclarecimento dos objetivos da reunião...

1 Contratação e capacitação đa equipe envolvida/ Formação e qualificação para os responsáveis do processo...

11 Formação de equipe de facilitadores... 
5 Popularizar a linguagem/ usar linguagem simples, melhor apresentação...

19 Aprimoramento da lei e das políticas de inclusão social...

21 Avaliação de todas as fases e correção do OP...

2 Disponibilizaçao pelo poder publico das informaçoes técnicas para antes e depois da deliberação...

9 Divulgação integral do processo / garantia de meios de comunicação social que integre todos os cidadaos... 15 Fazer planejamento participativo dos passos do OP (divulgação, execução, etc)...

7 Mapear e contatar a sociedade organizada...

3 Vontade política para a política de participação ...

18 Organização: motivar criação de entidades / espaços de integração...

17 Apresentar roteiro mínimo para apresentação das secretarias...

4 Comprometimento do conselheiro / conselho com o seu papel...

23 Implantar a modernização administrativa, agilizando e articulando as interfaces...

14 Integração entre facilitadores, gestores e agentes...

22 Organização e mobilização popular para cobrança e execução das deliberações...

24 Reforma administrativa...

12 Treinamento: formação política, técnica e intercâmbio...

20 Motivar a população através de planos de politicas públicas suprapartidários...

10 Realizar reuniões regulares com lideranças e população...

13 Imparcialidade e idoneidade do processo...

16 Audiências públicas regionalizadas para discutir propostas antes das plenárias... 
O CASO COMUSAN-SP E PARADIGMAS DA PARTICIPAÇĀO

Anexo 02: Roteiro de Entrevista

UNIVERSIDADEDE SÃO PAUILO

FACULDADE DESAÚDE PÚBLICA

DEPARTAMENTO DE PRÁTICAS E SERVICOS DE SAÚDE PÚBLICA

PESQUTSA SOBRE A PARTICIPAČÃO NO COMUSAN-SP

Entrevista $n^{\circ}$

Não é necessário identificar-se com o nome.

Sexo

Segmento

Em termos Gerais:

1. O QUE É PARTICIPAR PARA VOCÊ

2. O QUE SUA ENTIDADE PENSA SOBRE PARTICIPACÃO

3. Q QUE É PRECISO PARA PARTICIPAR BEM

4. QUAIS AS FACILIDADES GOU DIFICULDADES QUE SE TEM PARA PARTICIPAR

5. QUAIS AS DIFICULDADES DE SUA ENTIDADE EN PARTICIPAR

Em relação ao COMUSAN-SP:

6. COMO E PARTICIPAR NO CONSELHO

7. QUAIS AS FACILIDADES $/$ /ou DIFICULDADES EM PARTICIPAR NO CONSELHO

8. COM QUEM MAIS SE RELACIONA E/OU MELHOR

9. O QUE VOCE ACHA DAS ENTIDADES QUE PARTICIPAM NO CONMUSAN-SP

10. O QUE ACHA DA PARTICIPAÇÃO DESSAS ENTIDADES

No Campo Pessoal

11. COMO É SUA PARTICIPAÇÃO NO COMUSAN-SP

12. O QUE SUA ENTIDADE ACHA DA SUA PARTICIPAČ̃̃O

13. VOCE CONSEGUE DAR RETORNO DOS RESULTADOS DO COMUSAN-SP NA SUA ENTIDADE - COMO

14. O QUE PRECISA PARA PARTICIPAR MELHOR

15. QUAIS SUAS FACILIDADES e/ou DIFICULDADES PESSOAIS NESSA PARTICIPAÇÃO

16. VOCE CONHECE BEM OS ASSUNTOS TRATADOS NO CONSELHO

17. O QUE PRECISA PARA CONHECER MAIS O TRABALHO DO COMUSAN

18. VOCE TEM SE PREPARADO PARA SUA PARTICIPAÇĀO NO COMUSAN - COMO

Reflexäo

19. QUER FALAR MAIS ALGUMA COISA QUE EU NÄO TENHA PERGUNTADO 
Anexo 03

\section{CATEGORIZAÇÃO PRELIMINAR DE DIMENSÕES E CATEGORIAS PARA ANÁLISE DE CONTEÚDO \\ Definição do Problema (com base na proposta da OPAS 1990)}

Verificou-se na pesquisa exploratória a colocação de três questões referentes à Participação, que compreenderam as três principais dimensões.

a) Condições que determinam a participação (determinantes).

b) Características e dinâmicas de participação.

c) Processo e Cultura Participação.

Na dimensão das condições que determinam a participação encontram-se destacadas duas categorias:
a. I - Oportunidades
a. II - Obstáculos

Na dimensão das Características e Dinâmicas da Participação evidenciam-se três categorias:
b. I- Atores
b. II - Espaços
b. III - Processos

E por ultimo finalmente, na Dimensão dos Processo e Cultura de Participação encontram-se quatro categorias:

c. I - Relação Social - onde se dão as experiências participativas.

c. II - Transformações - onde se dá o exercício real da cidadania, se verifica o grau de transparência a serviço da democracia e as representações sociais da representatividade relativas aos segmentos estudados.

c. III - Avanços - na reciprocidade, no trabalho solidário, no bem estar coletivo e individual.

c. IV - Reflexões - avaliação e propostas quanto a efetividade e equidade.

Parâmetros para as abordagens trabalhadas:

Para a Dimensão das condições que determinam a participação utilizamos a técnica de entrevista com gravador e grupo focal, tendo como pano de fundo a Pesquisa Exploratória, 
realizada com os participantes do "Fórum de Democracia Participativa" (Hotel San Raphael, 04 e 05 de julho de 2002).

\section{CATEGORIZAÇÃO PRELIMINAR}

DIMENSÕES (OPAS 1990)

\section{Condições que a determinam \\ 2. Caracteristicas e dinâmicas \\ 3. Processos e Cultura}

Categorias:

I - Oportunidades

- Interno

- Externo

II - Obstáculo

- Interno

- Externo
Categoria:

I - Atores

II - Espaços

III - Processos
Categorias:

I - Relações Sociais

- Experiências

Participativas

II - Transformações

- Cidadania

- Transparência X Democracia

- Representação X Representatividade (p/segmento)

II - Avanço

- Equidade

- Efetividade

Para a Dimensão das Características e Dinâmicas da Participação, lançamos mão de pesquisa documental, nas ATAS de reuniões do COMUSAN-SP, nos relatórios e demais documentos de seus arquivos e do "diário de bordo", produzido na vivência das reuniões do COMUSAN-SP (ordinárias e extraordinárias, de grupos de trabalhos, comissão executiva e outras formas de organização / divisão de tarefas).

Para a Dimensão dos Processos / Cultura de Participação, utilizamos todo o material das dimensões anteriores, mais o referencial teórico da pesquisa bibliográfica e a técnica de Avaliação. 
Das diversas estratégias pesquisa, buscando na metodologia participativa formas de efetivar um estudo de cunho etnográfico avaliativa de modo a ( obter proporcionar) uma investigação que (formasse) explicações sobre o objeto de estudo e seu contexto, possibilitando a exploração dos elementos imprevisíveis e a utilização de diferentes técnicas de contribuição para construção do saber coletivo sobre o mesmo. objeto.

Cabe aqui explicar a intenção de buscar-se um caminho interativo no estudo deste

Tendo em vista que ter buscado parâmetros de participação que justifiquem as questões levantadas e os objetivos do COMUSAN-SP optou-se por procedimentos metodológicos e técnicas pertinentes aos conceitos pré-estabelecidos para o tema, por parecer compatível aos possíveis méritos e impactos desse canal institucional de participação na sociedade. 


\section{Anexo 04}

TRATADO DAS ONGs DE SEGURANÇA ALIMENTAR

\section{Rio-92}

\section{PREÂMBULO}

1. Por segurança alimentar se entende a situação em que um indivíduo, uma família, uma comunidade, uma região ou país alcançam níveis adequados de satisfação de suas necessidades nutricionais. A segurança alimentar inclui a erradicação da fome e da má nutrição crônicas. A segurança alimentar está mais assegurada quando os alimentos são produzidos, processados, armazenados e distribuídos localmente e disponíveis cotidianamente, independente das mudanças climáticas e outras variações.

2. Apesar do significativo incremento na produção de alimentos, ocorrido nos últimos anos, a insegurança alimentar tem aumentado. Recentes estimativas, realizadas pela FAO, indicam que as mortes nas áreas rurais do mundo em desenvolvimento em decorrência da fome, alcançaram mais de 15 milhões de pessoas em 1990. Nestas mesmas áreas, para o mesmo periodo, cerca de 500 milhões de pessoas, padeciam de desnutrição crônica. Paradoxalmente, isto ocorrem apesar de fortes incrementos na produção de alimentos.

3. Atualmente, o problema da insegurança alimentar a nível mundial é o resultado do caráter antidemocrático e desigual da distribuição e do acesso aos recursos (tais como terra, crédito, informação e incentivo), mais do que um problema global de produção alimentar. Como resultado, há uma concentração da produção em certos regimes e nas mãos de um número cada vez menor de produtores intensivos, em detrimento de outros regimes, dos pequenos produtores e da segurança alimentar local.

4. Ainda que a fome possa ser causada por conflitos políticos e sociais, perdas de colheitas ou desastres ecológicos, ela é produto principalmente da pobreza crônica - uma pobreza tão absoluta, que suas vítimas não possuem nem recursos para comprar comida, nem o controle sobre os recursos necessários para produzi-la.

5. O problema da segurança alimentar é geralmente tratado segundo dois enfoques: a procura da auto-suficiência alimentar local ou através de politicas comerciais. A política orientada para o 
comércio internacional, tal como promovida pelo Banco Mundial, pelo FMI e outras agências bilaterais e multilaterais, não supera a insegurança alimentar, mas a agrava.

6. A estratégia dominante de desenvolvimento orientada para as exportações resultou em numerosos problemas. Tais problemas se manifestam:

\# no fato de que apenas quatro empresas multinacionais controlam $90 \%$ do comércio mundial de cereais;

\# na dependência dos paises em desenvolvimento face a um pequeno número de produtos de exportação, que são também vulneráveis em decorrência da queda de preços das matérias primas;

\# na produção em grande escala de cultivos de alta rentabilidade em detrimento da produção alimentar local;

\# na progressiva marginalização dos pequenos produtores agricolas.

Ao pressionar em favor de politicas de exportação, a divida externa atual de numerosos países em desenvolvimento constitui um freio a sua segurança alimentar.

7. A dependência em relação à importação de alimentos conduz igualmente a numerosas dificuldades: o aumento da divida, problemas das balanças de pagamento e a flutuação de preços no mercado externo para os paises em desenvolvimento, que enfrentam forte redução em sua capacidade de importar. Os problemas de dependência face às importações e à ajuda alimentar envolvem também a dependência política, a vulnerabilidade em relação à imperância dos mecanismos de distribuição, o desestímulo aos produtores locais devido à redução dos preços dos alimentos, a concorrência com os alimentos tradicionais produzidos localmente e mudanças nos padrões de consumo. Além disso, os paises importadores se tornam vulneráveis às condições climáticas e politicas dos paises exportadores, não dispondo igualmente de mecanismos de controle sobre a qualidade dos alimentos importados, que sugerem tratamentos químicos específicos para conservação no transporte a longa distância.

\section{PRINCÍPIOS DA SEGURANCA ALIMENTAR}

1. A segurança alimentar é um direito humano fundamental. Cada um deve ter assegurado o acesso a uma alimentação saudável e de qualidade. Para assegurar o direito dos povos à alimentação, a segurança alimentar deve se fundamentar tanto quanto possivel na auto suficiência alimentar. A segurança alimentar é mais solidamente garantida quando a produção, o transporte e o consumo de 
produção local de alimentos constitui uma prioridade e quando a dependência em relação às importações alimentares é reduzida tanto quanto possivel, reconhecendo-se que as importações alimentares podem tornar-se necessárias para complementar a produção local.

2. A segurança alimentar é um elemento vital para o desenvolvimento sustentável. Os seres humanos tem o direito à dignidade da auto-suficiência alimentar. As políticas comerciais nacionais e internacionais não podem ameaçar esse direito.

3. O direito à alimentação não envolve apenas os aspectos materiais como quantidade, qualidade e acesso, mas também os aspectos culturais da alimentação. Os padrões de produção e consumo alimentar refletem a diversidade ambiental, cultural, politica e social das comunidades e sociedades, que deve ser respeitada e incentivada. Entretanto, os padrões não saudáveis de consumo alimentar devem ser desencorajados. As comunidades devem determinar o que é saudável e o que não é (destaque da autora). 


\section{Anexo 05 \\ Carta de Consentimento livre e esclarecido}

$\mathrm{Eu}$, aceito participar da entrevista para a qual fui dselecionado (a), que faz parte de uma pesquisa de tese de doutorado na Faculdade de Saúde Pública, na Universidade de São Paulo, de responsabilidade da Pesquisadora Roseli Lopes de Macedo Leal, que analisará as representações sociais de participação social e práticas decorrentes, por parte dos membros do Conselho Municipal de Segurança Alimentar e Nutricional de São Paulo - COMUSAN-SP, na Secretaria Municipal de Abastecimento - SEMAB.

A pesquisa será importante para fornecer subsídios para o desenvolvimento de projetos para o COMUSAN-SP, que poderão ser considerados na propositura de politicas públicas de Segurança Alimentar e Nutricional da SEMAB e de todos os serviços correlatos à área.

A entrevista será aberta, com questões semi-estruturadas para permitir maior expressão dos(as) entrevistados(as).

Tenho ciência de que minha participação é livre, não obrigatória, podendo ser interrompida por minha decisão a qualquer momento, sem qualquer prejuizo. Será garantido o anonimato do(a) entrevistado(a) e sigilo do conteúdo da entrevista, em particular.

Estou ciente de que, com minha autorização, a entrevista será gravada.

A pesquisadora compromete-se com o retorno dos resultados após o fim das pesquisas.

Para qualquer informação adicional estarei disponivel no telefone: 011.92487146 


\section{Anexo 06}

\section{DECRETO No 42.862, DE 13 DE FEVEREIRO DE 2003}

Institui o Conselho Municipal de Segurança Alimentar e Nutricional - COMUSAN-SP.

MARTA SUPLICY, Prefeita do Município de São Paulo, no uso de suas atribuições que lhe são conferidas por lei,

CONSIDERANDO ser objetivo da segurança alimentar e nutricional garantir a todos, de modo permanente, condições de acesso a alimentos básicos de qualidade e em quantidade suficiente, contribuindo, dessa forma, para uma existência digna, em um contexto de desenvolvimento integral da pessoa humana;

CONSIDERANDO constituir a segurança alimentar e nutricional direito inalienável da população, cuja concretização reclama a participação do poder público, da sociedade civil organizada e das entidades de classe afins;

CONSIDERANDO, finalmente, a conveniência de instituir-se, no âmbito municipal, colegiado composto dos referidos segmentos, objetivando viabilizar novas ações efetivas nessa área, bem assim otimizar as existentes,

\section{E C R E T A:}

Art. $1^{\circ}$. Fica instituído o Conselho Municipal de Segurança Alimentar e Nutricional COMUSAN-SP, vinculado à Secretaria Municipal de Abastecimento, com o objetivo de contribuir para a concretização do direito constitucional de cada pessoa humana à alimentação e à segurança alimentar e nutricional.

\section{Art. $2^{\circ}$. Caberá ao COMUSAN-SP:}

I - propor, acompanhar e fiscalizar as ações do governo municipal nas áreas de segurança alimentar e nutricional;

II - cooperar na articulação de áreas do governo municipal com as organizações da sociedade civil para a implementação de ações voltadas ao combate das causas da miséria e da fome, no âmbito do Município;

III - incentivar parcerias que garantam mobilização dos setores envolvidos e racionalização do uso dos recursos disponiveis;

IV - coordenar campanhas de conscientização da opinião pública com vistas à união de esforços: 
V - cooperar na formulação do plano municipal de segurança alimentar e nutricional;

VI - propor estratégias, normatizações, projetos, ações que implementem o Código Sanitário de São Paulo, no que concerne à segurança alimentar e nutricional, bem como opinar a respeito.

Art. $3^{\circ}$. O COMUSAN-SP será composto por 40 (quarenta) membros titulares e igual número de suplentes, com mandato de 24 (vinte e quatro) meses, observada a seguinte representação:

I - 10 (dez) representantes governamentais;

II - 20 (vinte) representantes da sociedade civil organizada;

III - 10 (dez) representantes de trabalhadores de áreas afins do setor de alimentos, por meio de suas respectivas entidades de classe.

Art. $4^{\circ}$. A representação governamental contará com:

I - 1 (um) representante da Secretaria Municipal de Abastecimento - SEMAB;

II - 1 (um) representante da Secretaria Municipal da Saúde - SMS;

III - 1 (um) representante da Secretaria Municipal de Educação - SME;

IV - 1 (um) representante da Secretaria Municipal de Assistência Social - SAS;

V - 1 (um) representante da Secretaria Estadual da Saúde;

VI - 1 (um) representante da Secretaria Estadual da Agricultura;

VII - 2 (dois) representantes de instituições públicas estaduais de ensino técnico/superior e de pesquisa;

VIII - 1 (um) representante do Ministério Extraordinário da Segurança Alimentar e Nutricional;

IX - 1 (um) representante do Ministério da Saúde.

Parágrafo único. Na falta de indicação de representante por quaisquer dos segmentos governamentais relacionados no "caput", a substituição far-se-á na forma que dispuser o regimento interno do Conselho, mantido o caráter público da representação. 
Art. $5^{\circ}$. Os representantes da sociedade civil organizada serão indicados em plenária específica da Conferência Municipal de Segurança Alimentar e Nutricional, contemplando as Comissões Regionais de Segurança Alimentar e Nutricional, na seguinte conformidade:

I - 5 (cinco) representantes dos movimentos populares com interface nas questões de segurança alimentar e nutricional, de movimentos sociais e comunitários;

II - 5 (cinco) representantes de entidades sindicais e associações gerais patronais e de entidades sindicais e associações patronais da área;

III - (três) representantes de instituições de ensino privado técnico/superior e de pesquisa;

IV - 3 (três) representantes de entidades de portadores de patologias e de entidades de portadores de deficiências;

V - 2 (dois) representantes de entidades prestadoras de serviços;

VI - 2 (dois) representantes da economia informal.

Art. $6^{\circ}$. Os representantes dos trabalhadores de áreas afins ao setor de alimentos, por meio de suas respectivas entidades de classe, serão indicados em plenária específica da Conferência Municipal de Segurança Alimentar e Nutricional, contemplando as Comissões Regionais de Segurança Alimentar e Nutricional, na seguinte conformidade:

I - 3 (três) representantes de entidades sindicais de trabalhadores de áreas afins à segurança alimentar e nutricional;

II - 4 (quatro) representantes de associações de trabalhadores de áreas afins à segurança alimentar e autricional;

III - 3 (três) representantes de entidades de classes profissionais e de associações de profissionais liberais ligadas à área de segurança alimentar e nutricional.

Art. $7^{\circ}$. Os suplentes dos representantes governamentais serão indicados pelos respectivos órgãos de origem e os representantes dos trabalhadores e os da sociedade civil organizada poderão ter, como suplentes, representantes de outras entidades, desde que aprovado na plenária específica da Conferência Municipal de Segurança Alimentar e Nutricional que indicar os membros do COMUSAN-SP.

Art. $8^{\circ}$. O COMUSAN-SP será composto, eleito e empossado em Conferência Municipal de Segurança Alimentar e Nutricional.

Art. $9^{\circ}$. A presidência do COMUSAN-SP será exercida por servidor da Secretaria Municipal de Abastecimento, designado pela Prefeita. 
Art. 10. O COMUSAN-SP terá uma Comissão Técnica Institucional, composta por representantes do setor público, entidades de classe, sociedade civil organizada e instituições científicas, cujo funcionamento será definido no regimento interno do Conselho.

Art. 11. O COMUSAN-SP elaborará seu Regimento Interno, a ser aprovado por maioria simples de seus membros e submetido à Prefeita, no prazo de 60 (sessenta) dias, contados da publicação deste decreto.

Art. 12. Sempre que se fizer necessário, poderá o COMUSAN-SP solicitar aos órgãos e entidades da Administração Pública Municipal dados, informações e colaboração para 0 desenvolvimento de suas atividades.

Art. 13. Caberá à Secretaria Municipal de Abastecimento dotar o COMUSAN-SP dos recursos materiais e humanos necessários ao seu funcionamento.

Art. 14. As despesas com a execução deste decreto correrão por conta das dotações orçamentária próprias, suplementadas se necessário.

Art. 15. Este decreto entrará em vigor na data de sua publicação.

PREFEITURA do MUNiCíPIo de SÃo PAULO, aos 13 de fevereiro de $2003,450^{\circ}$ da fundação de São Paulo.

MARTA SUPLICY, PREFEITA

LUIZ TARCISIO TEIXEIRA FERREIRA, Secretário dos Negócios Juridicos

JOÃO SAYAD, Secretário de Finanças e Desenvolvimento Econômico

VALDEMIR FLÁVIO PEREIRA GARRETA, Secretário Municipal de Abastecimento

Publicado na Secretaria do Governo Municipal, em 13 de fevereiro de 2003.

RUI GOETHE DA COSTA FALCÃO, Secretário do Governo Municipal 


\section{Anexo 07}

Instituições participantes da $1^{\text {a }}$ Gestão do COMUSAN-SP

20 representantes da sociedade civil organizada:

organizações não governamentais (entidades comunitárias)

Titulares:

- Instituto de Estudos Formação e Assessoria em Políticas Sociais - Pólis

- Pastoral da Criança

- Ação da Cidadania

- Amigos de Vila Albertina

- Associação de Agricultura Orgânica

Suplentes, pela ordem:

- Associação Monte Azul

- Movimento da Fraternidade das Igrejas Cristãs

- Liga das Senhoras Católicas

- União Federativa

- Associação Beneficente Vila Araguaia e Adjacências

entidades sindicais e associações gerais patronais e entidades sindicais e associações patronais da área:

Titulares:

- Federação do Comércio do Estado de São Paulo

- Associação Paulista de Supermercados

- Sindicato dos Hotéis, Restaurantes, Bares e Similares de São Paulo - SHRBS/SP

- Associação da Indústria de Panificação

- Associação Brasileira da Indústria da Alimentação

Suplentes, pela ordem:

- Sindicato do Comércio Varejista de Carnes Frescas do Estado de São Paulo

- Associação Brasileira de Supermercados

- Associação Paulista de Controladores de Pragas

- Sindicato das Indústrias de Panificação

- Associação Brasileira das Indústrias de Ingredientes para Alimentos

representantes de instituto de ensino privado superior, técnico e de pesquisa;

Titulares:

- Instituto Brasileiro de Orientação ao Consumidor

- SENAC

- Universidade São Judas Tadeu ( $1^{\circ}$ ano)

- Faculdades Integradas de São Paulo ( $2^{\circ}$ ano)

Suplentes, pela ordem:

- Universidade Anhembi-Morumbi

- SENAC

- Faculdades Integradas de São Paulo ( $1^{\circ}$ ano)

- Universidade São Judas Tadeu ( $2^{\circ}$ ano) 
representantes de entidades de portadores de patologias e entidades de portadores de deficiências:

Titulares:

- Associação dos Celíacos do Brasil - São Paulo

- Associação de Diabetes Juvenil

- Associação de Pais e Amigos de Fenilcetonúricos - São Paulo

Suplentes, pela ordem:

- Associação Pró-falcêmicos

- Associação dos Celíacos do Brasil - São Paulo

- Associação Paulista de Renais Crônicos

representantes de entidades prestadoras de serviços:

Titulares:

- ENS Consultores Associados

- Instituto de Hospitalidade ( $1^{\circ}$ ano)

- Instituto de Saúde, Segurança e Higiene no Trabalho do Setor de Serviços em

Hospedagem, Alimentação e Similares - ISSH ( $2^{\circ}$ ano $)$

Suplentes, pela ordem:

- Ponto Critico Consultoria em Alimentação

- SOS COZINHA Consultoria e Treinamento em Segurança Alimentar representantes de economia informal:

Titulares:

- Ass. Dos Camelos Ambulantes e Vendedores Autônomos Do Estado de São Paulo

- União Nacional dos Deficientes Físicos

Suplentes, pela ordem:

- Ass. Dos Camelos Ambulantes e Vendedores Autônomos Do Estado de São Paulo

- Sindicato dos Permissionários

10 representantes de trabalhadores de áreas afins ao setor de alimentos, através de suas respectivas entidades de classe.

representantes de entidades sindicais de trabalhadores de áreas afins à Segurança Alimentar e Nutricional;

Titulares:

- Sindicato dos Nutricionistas do Estado de São Paulo

- Sindicato dos Médicos Veterinários do Estado de São Paulo

- Sindicato dos Empregados em Empresas de Industrialização Alimentícia de São Paulo

e Região

Suplentes, pela ordem:

- Sindicato dos Nutricionistas do Estado de São Paulo

- Sindicato dos Farmacêuticos no Estado de São Paulo

- Sindicato dos Agentes Vistores do Município de São Paulo

associações de trabalhadores de áreas afins à Segurança Alimentar e Nutricional:

Titulares:

- Associação Paulista de Nutrição 
- Associação Paulista de Nutrição

- Associação Brasileira de Engenheiros de Alimentos

- Associação Brasileira de Engenheiros de Alimentos

Suplentes, pela ordem:

- Associação Paulista de Nutrição

- Associação Paulista de Nutrição

- Associação Paulista de Nutrição

- Associação Brasileira de Engenheiros de Alimentos

Conselhos de fiscalização das funções-fim.

Titulares:

- Conselho Regional de Nutricionistas $-3^{a}$ Região

- Conselho Regional de Química - $4^{\mathrm{a}}$ Região

- Conselho Regional de Nutricionistas - $3^{a}$ Região

Suplentes, pela ordem:

- Conselho Regional de Nutricionistas - $3^{a}$ Região

- Conselho Regional de Química - $4^{\mathrm{a}}$ Região

- Conselho Regional de Nutricionistas - $3^{a}$ Região

10 representantes governamentais:

- Secretaria Municipal de Abastecimento - SEMAB,

- Departamento de Inspeção Municipal de Alimentos - DIMA

- Secretaria Municipal de Saúde - SMS,

- Secretaria Municipal da Educação - SME,

- Secretaria Assistência Social - SAS,

- Secretaria Estadual da Saúde,

- Secretaria Estadual da Agricultura,

- Ministério da Saúde.

- Centro Estadual de Educação Tecnológica Paula Souza

- Faculdade de Medicina Veterinária e Zootecnia da Universidade de São Paulo

Obs.: todos, acima, com titulares e suplentes 


\section{Anexo 08}

Tabela A: Comissão Executiva da $1^{a}$ Gestão do COMUSAN-SP

\begin{tabular}{|c|c|}
\hline \multirow{2}{*}{$\begin{array}{l}\text { MEMBROS TITULARES } \\
\text { Ação da Cidadania }\end{array}$} & MEMBROS SUPLENTES CORRESPONDENTE \\
\hline & $\begin{array}{l}\text { POLIS - Inst. De Estudos Formação } \\
\text { e Assessoria em Politicas Sociais }\end{array}$ \\
\hline $\begin{array}{l}\text { ACELBRA - Associação dos Celíacos } \\
\text { do Brasil }\end{array}$ & ADJ - Associação do Diabetes Juvenil \\
\hline $\begin{array}{lll}\text { APAS } & \text { Associação } & \text { Paulista } \\
\text { de Supermercados } & & \end{array}$ & $\begin{array}{l}\text { AIPAN - Associação das Indústrias de Panificação } \\
\text { e Confeitaria de São Paulo }\end{array}$ \\
\hline Universidade São Judas Tadeu & AAO - Associação de Agricultura Orgânica \\
\hline CRN.3 - Conselho Regional de Nutrição & CRQ.4 - Conselho Regional dos Químicos \\
\hline $\begin{array}{l}\text { SINESP - Sindicato dos Nutricionistas } \\
\text { de São Paulo }\end{array}$ & APAN - Associação Paulista de Nutrição \\
\hline SMS - Secretaria Municipal de Saúde & SAS - Secretaria de Assistência Social \\
\hline 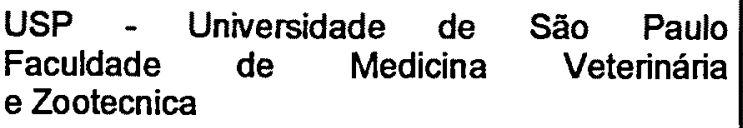 & $\begin{array}{l}\text { SEMAB/DIMA - Departamento de Inspeção } \\
\text { Municipal de Alimentos }\end{array}$ \\
\hline $\begin{array}{l}\text { Coordenadoria da Comissão Executiva } \\
\text { SEMAB-G (Suplente) }\end{array}$ & \\
\hline
\end{tabular}




\section{Anexo 09}

Tabela B: PLANO DE METAS DO COMUSAN-SP PARA 2003 (ANEXO à Ata da 10" reuniăo ordinánia)

\begin{tabular}{|c|c|c|}
\hline METAS & ESTRATEGIAS & CRONOGRAMA \\
\hline 1. Legalizacão do COMUSAN-SP & 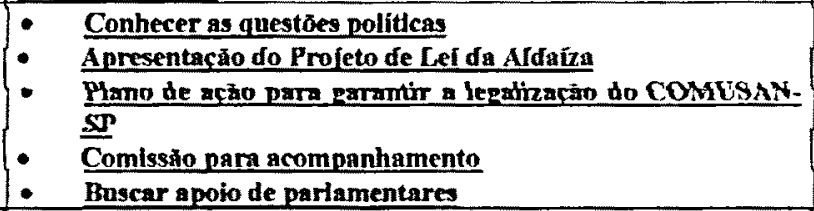 & MARCO \\
\hline 2. Estruturar o COMUSAN-SP & - Fstrutura fisica, matertal e pessoal & MARCO \\
\hline 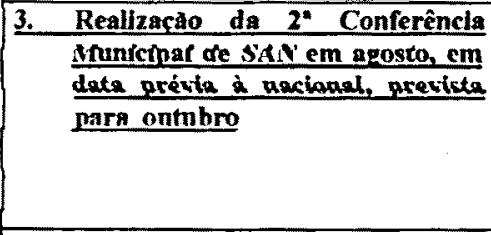 & 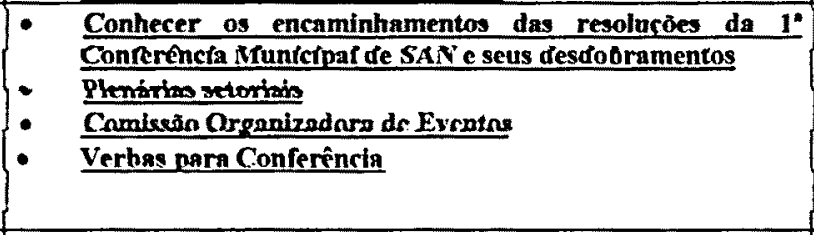 & $\begin{array}{l}\text { MARTYY } \\
\text { JINHO } \\
\text { FEVEREIRO } \\
\text { EEV.AKEO. }\end{array}$ \\
\hline 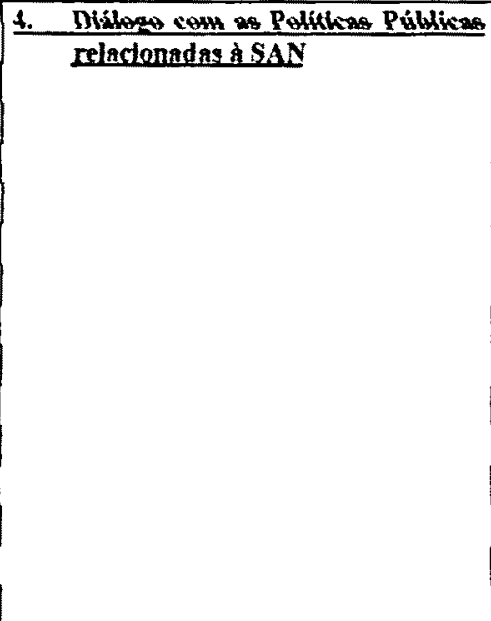 & 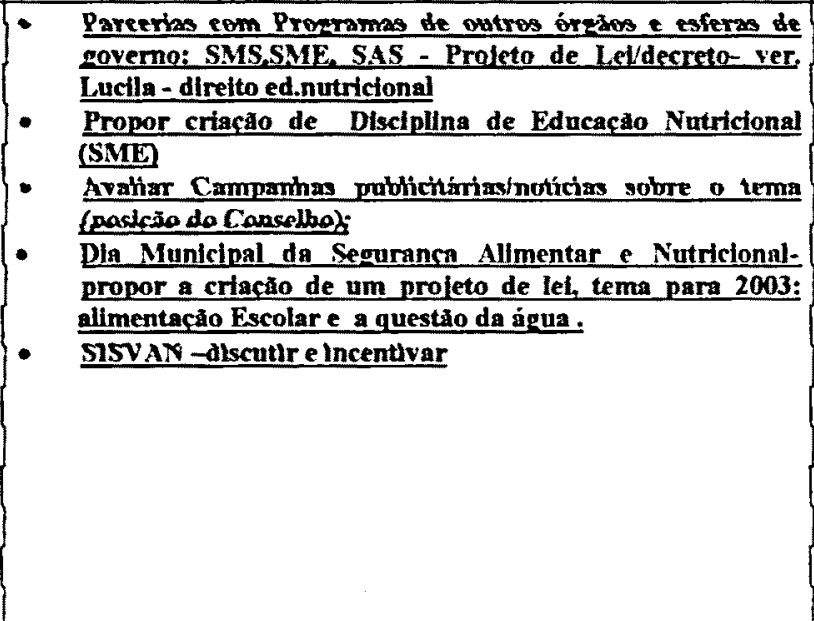 & $\begin{array}{l}\frac{2 * \text { quinzena de }}{\text { narco }} \\
\text { JANEIRO A } \\
\text { DEZEMBRO }\end{array}$ \\
\hline $\begin{array}{l}\text { 5. Inegrisio to CONIUSAN-SP } \\
\text { Proegrama Nacional Fome Zero }\end{array}$ & 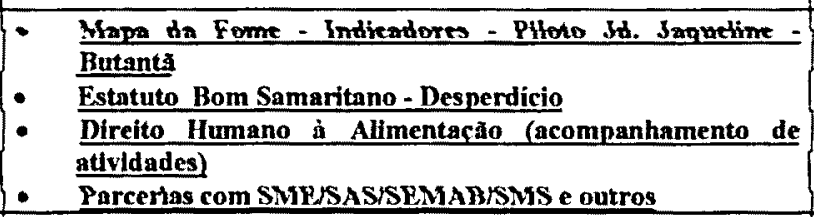 & $\frac{\text { FEVEREIRO }}{\text { A DEZEVIBRO }}$ \\
\hline 6. Formerios de Comscthetines & 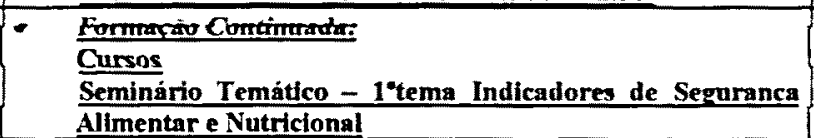 & $\frac{\text { MAIO }}{\text { FEVEREIRO }}$ \\
\hline $\begin{array}{l}\text { 7. Buscar recursos municipais e criar } \\
\text { formo SidN. }\end{array}$ & - Ter orcamento, captar doacōes, patrocinios.- & JAN A DEZ \\
\hline 8. Pramaver a COMUUSAN-SP & 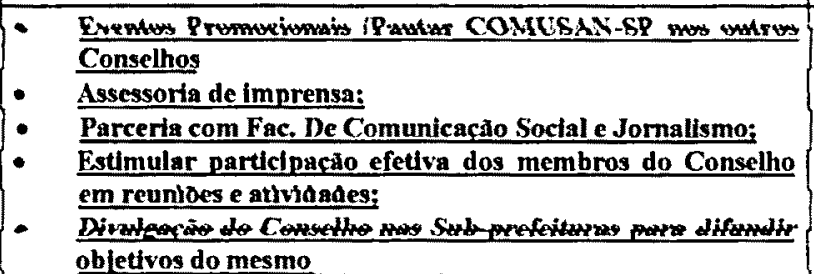 & IAN A DEZ \\
\hline 9.Plano de Metas para 2004 & 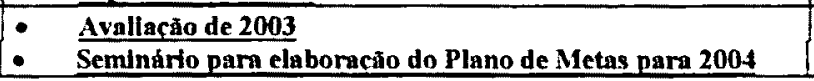 & NOVEMBRO \\
\hline
\end{tabular}




\section{Anexo 10}

Propostas aprovadas pelo COMUSAN-SP, produto da I CONFERÊNCIA MUNICIPAL DE SEGURANÇA ALIMENTAR E NUTRICIONAL DE SÃO PAULO:

SUB-TEMAS PROPOSTOS PELOS GRUPOS DE TRABALHO A PARTIR DA $1^{\text {a }}$ CONFERÈNCIA MUNICIPAL DE SEGURANÇA ALIMENTAR E NUTRICIONAL DE SÃO PAULO:

- aLimentação escolar

- VENDA diRETA a baIXo CUSTO OU PROGRAMA dE ALIMENTAČ̃o +

- DOAÇÃo dE ALIMENTOS

- ESCLARECIMENTOS À POPULAÇ̃̃o/CAMPANHAS

- VIGILÂNCIA SANITÁRIA

- gaRANTIA DE PROFISSIONAIS +

- CAPACITAÇ̃̃o TÉCNICA +

- PESQUISA

OBS.: A seguir as propostas revistas pela Plenária de 09/05/2002.

PROPOSTAS DE GRUPOS DE TRABALHO:

4. Acessibilidade

$\$$ Políticas Públicas

b Qualidade e consumo

\section{SUB-TEMA: ALIMENTAÇÃO ESCOLAR}

\section{PROPOSTAS}

1) Deve o Governo Municipal garantir o fornecimento de alimentação escolar adequada às crianças de diversas faix etárias, atendidas em creches, escolas e Projetos Institucionais, abrangendo todo o período em que as mesm permaneçam nas Unidades de Ensino e/ou Equipamentos sociais, considerando ainda as diferentes patologias e su. restrições alimentares. Os nutricionistas deverão assumir a responsabilidade técnico de todo o planejamento, supervisão educação alimentar direcionados a esses grupos, sendo a ação educativa extensiva a pais, familiares, professores funcionários dos Estabelecimentos

2) Deve, ainda, o Governo Municipal proibir a existência/instalação de cantinas em Unidades Escolares, bem como a ven de salgadinhos, balas, refrigerantes e outros alimentos supérfluos, nas dependências desses estabelecimentos públicos. 


\section{PROPOSTAS}

3) Que a alimentação escolar seja baseada no envio de alimentos in natura, considerados os hábitos alimentares regionais, com mai diversificação de gêneros e melhor qualidade, reduzindo o fornecimento de alimentos industrializados, procurando adequar sistema de compras aos alimentos de maior aceitação e prevendo a aquisição de alimentos para as crianças com patologias q4 impõem restriçð̃es alimentares no seu dia-a-dia, possibilitando adaptaçðes nos cardápios da merenda.

4) Que seja desenvolvido um projeto envolvendo as Secretarias Municipais de Saúde, Educação, Abastecimento e Associações Patologias e comunidade, para viabilizar o levantamento de dados relativos às crianças com patologias ligadas a restriçó alimentares, o qual poderá ser por meio de:

(4) manual de orientação aos funcionários das Escolas;

(5) aplicação de questionário nas Escolas, no ato da matricula;

(4) trabalho desenvolvido pela Secretaria de Saúde, por intermédio do SISVAN - Sistema de Vigilância Alimentar e Nutriciona

5) Garantir a inclusão do tema segurança alimentar junto aos Conselhos Gestores das Escolas.

\section{PROPOSTAS}

6) Que a alimentação escolar seja baseada no envio de alimentos in natura, com maior diversificação de gêneros e melh qualidade, reduzindo o fomecimento de alimentos industrializados, procurando adequar o sistema de compras aos alimento de maior aceitação e prevendo a aquisição de alimentos para as crianças com patologias que impðem restrições alimentar no seu dia-a-dia possibilitando adaptações nos cardápios da merenda e estabelecendo critérios de sanidade dos alimento oferecidos à rede de ensino para a produção de refeições e lanches.

OBS.: texto encaminhado também para o Grupo de Trabalho de POLÍTICAS PÚBLICAS.

7) Que seja criado pelo Governo Municipal o cargo de MERENDEIRA, possibilitando uma formação especifica e exclusi para essa função. 


\section{PROPOSTAS DE GRUPO DE TRABALHO:}

\$ Acessibilidade

\& Políticas públicas

\section{SUB-TEMA: VENDA DIRETA A BAIXO CUSTO OU PROGRAMA DE ALIMENTAÇÃO}

\section{PROPOSTAS}

1) O Governo Municipal deve apoiar e estimular a produção e comercialização de produtos orgânicos, de modo a proteger saúde dos trabalhadores, consumidores e meio ambiemte.

Deve, ainda, flexibilizar a legislação de vigilância sanitária de modo a não excluir os pequenos produtores e distribuidores trabalhar, viabilizando a sua regularização, bem como a educação sanitária e a promoção à saúde.

2) O Governo Municipal deve desenvolver e apoiar a criação de restaurantes populares, em lugares de grande fluxo trabalhadores, principalmente de baixa renda, utilizando como modelo os projetos já existentes bem sucedidos.

3) Que uma parte dos produtos agrícolas adquiridos pelos segmentos institucionais do município provenha dos agricultor familiares do Estado de São Paulo.

4) Incentivar os agricultores familiares e a população da periferia agregar valores aos produtos agrícolas através de $\mathrm{u}$ programa de apoio à produção em pequena escala a ser implantado no município de São Paulo.

\section{PROPOSTAS}

5) Redução dos impostos incidentes sobre os produtos que constituem a cesta básica de alimentos e os produtos de higier e limpeza, especificamente ICISS PIS COFINS

6) Governo Municipal, juntamente com o Governo Estadual, deverá desenvolver politicas de abastecimento aliment popular, com a oferta de alimentos de boa qualidade fisico-quimica, biológica, nutricional e sensorial, com preços justo em áreas urbanas de baixa renda, articulando os pequenos produtores, pequenos varejistas e consumidores.

Essa política governamental ampla deverá contemplar várias frentes de ação, para possibilitar maior acesso à alimentação menor peso desse item no orçamento familiar, através de:

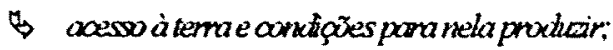

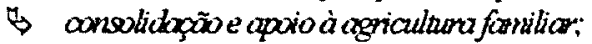

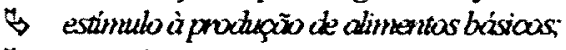

4) estimulo àcriacä̃o de fortalecimento de pequenas emprexas urbonas e nurais;

4) estimulo co associativisno es cooperativisno:

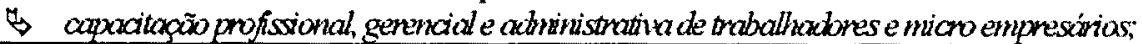


5) epoio ìsiniciatives de Crédto Popular;

b iniciativas de garantia de Renda linima.

4 abastecimento alimentor a prescas justas para áneas de baixa renda articulando o procutur com o consumidor.

PROPOSTAS DE GRUPO DE TRABALHO:

b) Qualidade e consumo

SUB-TEMA: DOAÇÃO DE ALIMENTOS

\section{PROPOSTAS}

1) Cumprimento de legislação específica permitindo a doação de alimentos diretamente às unidades receptoras, co transferência de responsabilidade, inclusive com relação a retirada e transporte.

2) Apoiar as Entidades que estão propondo a aprovação de Legislação Federal (Estatuto do Bom Samaritano)

\section{PROPOSTAS DE GRUPO DE TRABALHO:}

4. Acessibilidade

\$) Políticas públicas

b Qualidade e consumo

4. Vigilância em Saúde

\section{SUB-TEMA: ESCLARECIMENTOS Ȧ POPULAÇÃO/CAMPANHAS}

\section{PROPOSTAS}

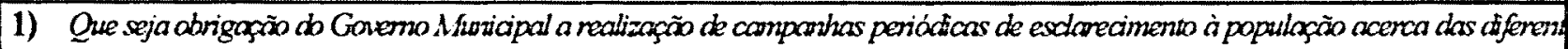

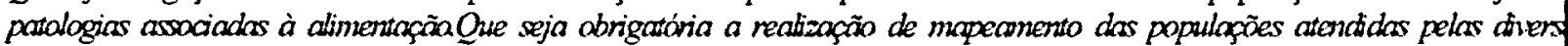

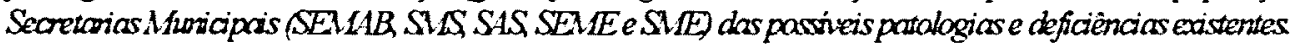

2) Govemo Muricipal deve cricr, manter ou anpliar o Prograna de Banco de Leite Humano e intensificor componhas de deitomen matemo, passibibitando melhores condịäes de saride à populaçäo infantil

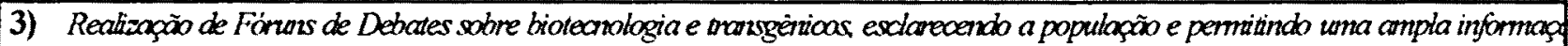
sobre as hemax 
4) Que os estabelecimentos varejistas (bares, restaurantes, lanchonetes, mercados, padarias, etc) que comercializa alimentos sejam obrigados a informar os ingredientes desses produtos, de forma acessível e clara ao consumido para evitar o consumo de alimentos/produtos impróprios por parte de pessoas com restriçð̃es alimentares.

\section{PROPOSTAS}

5) Informar, capacitar e inserir componentes de segurança alimentar em programas públicos e conselhos municipa que guardem relação com 0 alimento.

6) Incentivar, atranés de Föruns Regionais, a realização de palestras cum a participação dos diferentes segment (entidades de classe, patronais, bairros; associaçũes, entre outros) abordando neçōes de legislação sanitári administração geral, direitos da boa alimentação, incluindo a discussão de cardápios da merenda escolar autonomia na compra de gèneros, apresentando propostas para amenizar os problemas de segurança aliment no municipio.

7) Disponibilizar a legislação sanitária municipal por meio dos meios de comunicação eletrônicos.

8) Elaborar um programa de educação sanitária e nutricional para as escolas públicas e privadas, com materi padronizado, destinado às diferentes faixas etárias aplicado por profissionais capacitados.

9) Fazer a efetiva utilização da Ouvidoria Pública no tocante a queixas e denúncias recebidas pelo COMUSAN-S quando não couber ao Conselho a ação pertinente.

10) Incentivar a participação popular nos Conselhos Distritais de Saúde, para promover o controle social relativo segurança alimentar e nutricional.

\section{PROPOSTAS}

11) Inserir $e$ divulgar os conceitos de Segurança alimentar e nutricional e as ações da vigilância em saúde, dentro Programa Saude da Familia - PSF e para a comunidade.

12) Educação Nutricional e higiene dos alimentos para agentes comunitários de saúde, dados por profission capacitado em segurança alimentar e nutricional ( o GT do COMUSAN/SP definirá quais serão os profissionais).

13) Ampliar dentro dos temas transversais do Ensino Fundamental da Rede Municipal, assuntos sobre vigilância dd alimentos e os valores nutricionais.

14) Instituir evento anual em comemoração ao Dia Mundial da Alimentação na Rede Municipal de Ensino sobre tema Segurança Alimentar e Nutricional, em parceria com as instituiçðes e órgãos públicos, e com o apoio $\mathrm{c}$ COMUSAN-SP. 


\section{PROPOSTAS DE GRUPO DE TRABALHO:}

4) Acessibilidade

\$ Políticas públicas

7. Qualidàde e consumo

G. Vigilância em saúde

\section{SUB-TEMA: VIGILÂNCIA SANITÁRIA}

\section{PROPOSTAS}

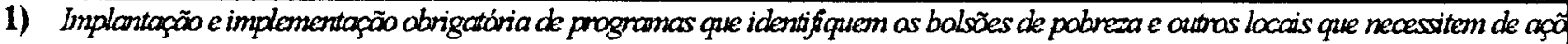

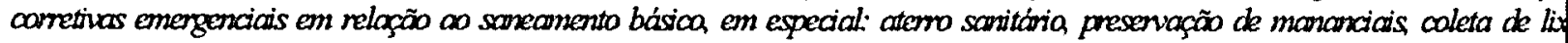

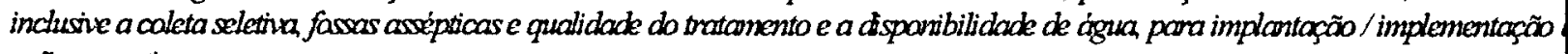
açäescorretivas

2) Inctuir ou adkptor ao Código Saritćnio Municipal vigente, açöes exeqüíneis, bem como nomatizar o comércio ambulante de aliment com pasterior copacitagão de manipuladores ou vendedores de afmentos em locais públicas.

3) Deve o Gaveno Municipal proceder à análíse de produtas in nothara comencializadas na cidade de Sx̃o Paulo, do ponto de vista higiênic sanitóio, com a devida ênfase na legislação que regulanenta a utilização cometa das agrotóxicas, adtivas e outras substàncias present mas alimentas.

4) Disponibibzar a legislação scanitária municipal pelainternet.

\section{PROPOSTAS}

5) Criar uma resolução conjunta entre a Secretaria de Abastecimento Municipal - SEMAB, através da Vigilânc Sanitária e Secretaria de Agricultura e Abastecimento de São Paulo (Escritório de Defesa Agropecuária de Sã Paulo), para promover o controle de resíduos de agrotóxicos, hormônios e antibióticos nos alimentos de orige vegetal e animal comercializados e /ou cultivados no município de São Paulo.

Obs: Esta propostainchi a propasta de n. ${ }^{\circ} 9$ do GT Acessibilidade, sub tema: vigilância sanitária 
6) Que seja criada uma Unidade de VGGLANCLA EM SAUDE em parceria com cada Administração Regional o Organização Administrativa Descentralizada (Sub - prefeituras), tornando a Vigilância em Saúde descentralizad para que tentha poder de promoção e fiscalização no comércio informal de alimentos e coibindo o comérc. clandestino.

7) Solicitar à Câmara Municipal de São Paulo que sejam elaborados projetos de incentivos fiscais e tributários para empresas que investirem, comprovadamente, em projetos de segurança alimentar e nutricional, com aprovação o COMUSAN-SP

8) Solicitar a aprovação, pela Câmara Municipal, do Código Municipal de Controle de Vetores e Pragas Urbana tendo como objetivo a implantação do controle integrado de Pragas, para minimizar a ação prejudicial dessas prag: urbanas, bem como a diminuição do uso de pesticidas, em caráter de urgência.

9) Fiscalização efetiva e contínua dos estabelecimentos que comercializam alimentos por profissionais especializad e capacitados.

\section{PROPOSTAS}

10) Criação do SERVIÇO DE INSPEÇÃO MUNICIPAL (SIM), com poderes para fiscalizar o cumprimento legislação que regulamenta as atividades de abate e comércio de produtos de origem animal.

11) Criação de legislação especifica para o segmento do comércio varejista, supermercadistas, com participação o setor.

12) A administração municipal deverá ter número de equipes de fiscalização suficientes para atender ao número estabelecimentos que comercializem alimentos, dando prioridade aos locais com pendências e prazos dados duran as vistorias, valorizando o enfoque educativo das ações.

13) Que as ações de vigilância em saúde se dêem de forma integrada de acordo com o Sistema Único de Saúde - SUS

14) Mudança do modelo cartorial e policialesco das ą̧ð̃es de vigilância em saúde para um modelo que garanta controle social, a promoção a saúde e a inclusão social, formado por equipes multiprofissionais capacitadas comprometidas com a ética

\section{PROPOSTAS DE GRUPO DE TRABALHO:}

6) Acessibilidade

t) Qualidade e consumo

\section{SUB-TEMA: GARANTIA DE PROFISSIONAIS}

\section{PROPOSTAS}

1) Garantir a participação de profissionais habilitados da área de alimentação nas equipes dos projetos sociais qu envolvam alimentağ̃o, segurança alimentar e nutricional (renda-mínima, bolsa alimentaç̃o, PSF, entre outros).

2) Estabelecer a exigència de Responsável Técnico qualificado e habilitado, reciclado periodicamente na área 
qualidade e segurança alimentar para restaurantes comerciais e estabelecimentos que manipulem, industrializem comercializem alimentos.

Obs: Esta proposta foi destacada para ser objeto de estudo de um GT composto por: Idati (CRN3), Benedito (AIPAN Maria Isabel (SINESP), Ana Marisa (DIMA), Liliana (ABEA) e Rogério (SOS Cozinha).

\title{
PROPOSTAS DE GRUPO DE TRABALHO:
}

t) Qualidade e consumo

\section{SUB-TEMA: CAPACITAÇÃO TÉCNICA}

\section{PROPOSTAS}

1) Criação de cursos obrigatórios de formação básica em higiene na manipulação de alimentos exigidos para toda equipe dos estabelecimentos de produção e comercializafão de alimentos. ministrados por órgãos públicos privados. capacitados e credenciados, ficando a contratação desses profissionais vinculada à apresentação o referida habilitafão. a qual deverá ser renovada periodicamente.

2) Que as integrantes das equipes de fiscalização tenham formaç̃̃o acadêmica relacianada sam a atividade vigilância sanitárian, ex: Nutricionistas, Engenheiros de Alimentos, Veterinários e Agrònomos

3) Estabelecer a obrigatoriedade de qualificação e atualização dos profissionais das equipes de fiscalização através cursos sobre segurança alinzentar e mutricional promovidos pelas próprias institứções municipais.

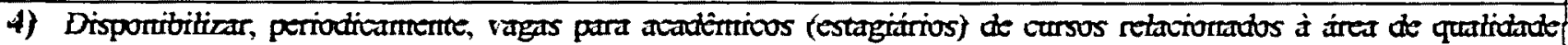
segurança alimentar nos depanamentos de vigilância em saúde e alimemtação escolar.

\section{PROPOSTAS DE GRUPO DE TRABALHO:}

\author{
t) Acessibilidade \\ b) Políticas públicas \\ † Qualidade e consumo
}

\section{SUB-TEMA: PESQUISA}

\section{PROPOSTAS}

1) Sugerimos que se faça um estudo cientifico para testar a hipótese de que a farinha da folha de mandioca seja um produ mais rico em ferro. mais barato e de efeitos mais saudáveis e rápidos que o sulfato ferroso industrializado, assim como. multimistura .

Obs: Para estudo desta proposta foi formado o GT formado por: Christiane (Polis). Regina Pontin (SMS). Cristir (Associação Amigos de Vl. Albertina). Irmã Cecilia (Pastoral da Criança), Nadja (Ação da Cidadania) e Sr. Ferrei (SINDEIA)

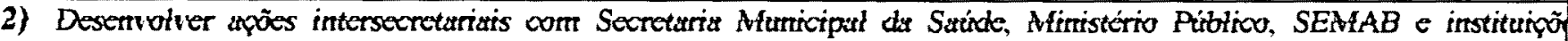
públicas de ensino visando a seguranģa alimentar de populações indigenas com controle de carências nutricionais, e especial a desnutriçión de forma a assegurar aroesso ato alimento. 
3) Que o COMUSAN/SP incentive as Instituições de Ensino e Pesquisa, bem como as instituições financiadoras para gu desenvolvam pesquisas relacionadas à alimentação, com aprovação de um Comitê de Ética em Pesquisa.

Obs : Para o desenvolvimento desta proposta foi instituído o GT formado por: Sra Cristiane (Polis), Sra. Simone (Fac. Me Vet./USP), Sra. Nina (APAN), Sra. Nadja (Ação da Cidadania), Sra. Maria Luisa (USJT) e Sra Roseli (DIMA), para estudar criação de um fundo para pesquisa.

\section{PROPOSTAS}

4) Propor a unificação dos parämetros laboratoriais para análise de alimentos, vigentes nas legislação Municipal, Estadual Federal.

Obs: GT para estudar a proposta 12 do GT Políticas Públicas, sub-tema pesquisa com os seguintes componentes:

Sra. Ana Marisa (DIMA). Sra. Simone (FAC.MED.VET/USP). Sr. Deodato (Sind. dos Farmacêuticos de São Paulo)

OBS: As propostas foram aprovadas por consenso, com exceção das de número:

3 - Qualidade e Consumo

12 - Acessibilidade

12 - Políticas Públicas

19 - Políticas Públicas

REDIGITADO EM 08/07/02 


\section{Anexo 11}

NOVA COMPOSIÇÃO DO COMUSAN-SP

$2^{2}$ Gestão, publicada no Diário Oficial do Municipio de 16 de outubro de 2003.

\section{COMUNICADO}

Segue a nova composição do CONSELHO MUNICIPAL DE SEGURANÇA ALIMENTAR E NUTRICIONAL DE SÃo PAULO, a ser empossada na Reunião Ordinária de 11 de dezembro de 2003, em local e horário a serem divulgados com antecedência, munidos dos documentos necessários. Para que tomem posse oficialmente todas as Instituições eleitas devem provar sua constituição jurídica, com CNPJ e Estatuto registrado em cartória, em rerox autenticada, encaminhados por oficio, em papel timbrado da mesma, indicando o nome, RG e cargo de quem representará na gestão 2003/2005. As mesmas poderăo ałterar os nomes de seus representantes sempre que entenderem necessário, mas somente os nomes formalizados poderão votar nas reuniões do Conselho.

\section{COMUSAN-SP, gestão 2003/2005}

\section{GOVERNO}

01 Representante da Secretaria Municipal de Abastecimento - SEMAB (Titular e Suplente)

01 Representante da Secretaria Municipal de Saúde - SMS (Titular e Suplente)

01 Representante da Secretaria Municipal de Educação - SME (Titular e Suplente)

01 Representante da Secretaria Municipal de Assistência Social - SAS (Titular e Suplente)

01 Representante da Secretaria Estadual da Saúde (Titular e Suplente)

01 Representante da Secretaria Estadual da Agricultura (Titular e Suplente)

02 Representantes de instituições públicas estaduais de ensino técnico / superior e de pesquisa
$>$ Titular:
$>$ Suplente:
$>$ Titular:
Centro Estadual de Educação Paula Souza
$>$ Suplente:
Centro Estadual de Educação Paula Souza

Universidade de São Paulo - Faculdade de Saúde Pública

Universidade de São Paulo - Faculdade de Medicina Veterinária

01 Representante do Ministério Extraordinário da Segurança Alimentar e Nutricional (Titular e Suplente)

01 Representante do Ministério da Saúde (Titular e Suplente)

\section{SOCIEDADE CIVIL}

05 Representantes dos movimentos populares 
$>$ Titular: Ação da Cidadania

$>$ Suplente: Movimento Alternativo de Transformação Social

$>$ Titular: Movimento Nacional de Luta pela Moradia

> Suplente: Casa da Criança e Adolescente Betinho

Titular: Conselho Popular Saúde Jabaquara

$>$ Suplente: Centro Social Comunitário Jd. Lurdes

$>$ Titular: Associação Vila Araguaia

$>$ Suplente:' Sociedade Amigos de Vila Zilda e Pq Casa de Pedra

Titular: Movimento de Moradia Sudeste x Centro - Entidade Caico

$>$ Suplente: TEN-YAD

05 Representantes de entidades sindicais e associaçōes gerais patronais e de entidades sindicais e associações gerais patronais da área

$>$ Titular: Federação do Comércio do Estado de São Paulo

$>$ Suplente: Sindicado do Comércio Varejista de Carnes Frescas do Estado de São Paulo

$>$ Titular: Associação Paulista de Supermercados

Suplente: Associação Brasileira de Supermercados

$>$ Titular: Associação Paulista de Controladores de Pragas Urbanas

$>$ Suplente: Associação Paulista de Supermercados

$>$ Titular: Associação Brasileira das Indústrias de Alimentos

$>$ Suplente: Sindicado do Comércio Varejista de Carnes Frescas do Estado de São Paulo

$>$

$>$ Titular: Associação Brasileira da Indústrias de Ingredientes para Alimentos

$>$ Suplente: Associação Paulista de Controladores de Pragas

03 Representantes de instituições de ensino privado técnico / superior e de pesquisas 2004

$>$ Titular: Universidade São Judas - USJ

$>$ Suplente: Universidade São Judas - USJ

$>$ Titular: Faculdades Integradas de São Paulo - FISP

$>$ Suplente: Faculdades Integradas de São Paulo - FISP

Titular: Instituto Brasileiro de Orientação ao Consumidor - IBOC

$>$ Suplente: Centro Universitário Nove de Julho - UNINOVE 2005

$>$ Titular: Universidade São Judas - USJ

Suplente: Universidade São Judas - USJ

$>$ Titular: Faculdades Integradas de São Paulo - FISP 
$>$ Suplente: Faculdades Integradas de São Paulo - FISP

Titular: Centro Universitário Nove de Julho - UNINOVE

$>$ Suplente: Instituto Brasileiro de Orientação ao Consumidor - IBOC

03 Representantes de entidades de portadores de patologias e de entidades de portadores de deficiências

$>$ Titular: $\quad$ ACELBRA - Associação dos Celíacos do Brasil

$>$ Suplente: APAH - Associação Paulista de Atenção ao Hipertenso

$>$ Titular: APAF - Associação de Pais e Amigos de Fenilcetonúricos

$>$ Suplente: Conselho Municipal da Pessoa com Deficiência

$>$ Titular: Movimento pelo Direito das Pessoas com Deficiência

$>$ Suplente: União Nacional dos Deficientes Físicos

02 Representantes de entidades prestadoras de serviços

2004

$>$ Titular:

$>$ Suplente: INTEGRA - Segurança Alimentar

$>$ Titular: $\quad$ A.A.O. - Associação de Agricultura Orgânica

$>$ Suplente: $\quad$ INSTITUTO POLIS - Estudos, Formação, Assessoria em Políticas Sociais

\section{5}

$>$ Titular:

$>$ Suplente:

$>$ Titular:

$>$ Suplente:
INTEGRA - Segurança Alimentar SOS Cozinha S/C

INSTITUTO POLIS - Estudos, Formação, Assessoria em Políticas Sociais A.A.O. - Associação de Agricultura Orgânica

02 Representantes da economia informal

\section{$>$ Titular:}

Suplente:

Titular:

$>$ Suplente:
ACOMESP - Associação dos Comerciantes, Ambulantes, e Prestadores de Serviços em Pontos Fixos nas Vias e Logradouros Públicos no Município de São Paulo

ACOMESP - Associação dos Comerciantes, Ambulantes, e Prestadores de Serviços em Pontos Fixos nas Vias e Logradouros Públicos no Município de São Paulo

SINPESP - Sindicato dos Permissionários em Pontos Fixos nas Vias e Logradouros do Municipio de São Paulo

$$
\text { SINPESP - Sindicato dos Permissionários em Pontos Fixos nas Vias e }
$$

Logradouros do Município de São Paulo 


\section{TRABALHADORES DA ÁREA}

03 Representantes de entidades sindicais de trabalhadores de áreas afins à segurança alimentar e, nutricional:

$>$ Titular: $\quad$ Sindicato dos Nutricionais do Estado de São Paulo

$>$ Suplente: Sindicato dos Médicos Veterinários de São Paulo

Titular: Sindicato dos Farmacêuticos de São Paulo

$>$ Suplente: Sindicato dos Trabalhadores dos Hotẻis e Similares

$>$ Titular: $\quad$ Sindicato dos Agentes Vistores do Município de São Paulo

$>$ Suplente: $\quad$ Sindicato dos Médicos Veterinários de São Paulo

04 Representantes de associações de trabalhadores de áreas afins à segurança alimentar e, nutricional:
$>$ Titular:
APAN - Associação Paulista de Nutrição
$>$ Suplente:
APAN - Associação Paulista de Nutrição
$>$ Titular:
$>$ Suplente:
ABEA - Associação Brasileira dos Engenheiros de Alimentos
$>$ Titular:
Centro Acadêmico Emílio Ribas
$>$ Suplente:
APSA - Associação Paulista de Segurança Alimentar
$>$ Titular:
ABPA - Associação Brasileira Para Prevenção de Acidentes
$>$ Suplente:
SPMV - Sociedade Paulista de Médicos Veterinários
Colégio Brasileiro de Medicina Veterinária

03 Representantes de entidades de classes profissionais e de associações de profissionais liberais, ligados à área de segurança alimentar e, nutricional.
$>$ Titular:
Conselho Regional de Química - $4^{x}$ Região
$>$ Suplente:
Conselho Regional de Química - 4" Região
$>$ Titular:
Conselho Regional de Nutricionistas - SP
$>$ Suplente:
Conselho Regional de Nutricionistas - SP
Titular:
Conselho Regional de Medicina Veterinária - SP
$>$ Suplente:
Conselho Regional de Medicina Veterinária - SP 


\section{Anexo 12}

\section{Conferência Municipal de Segurança Alimentar e Nutricional de São Paulo (realizada de 08 a 10 de outubro de 2003)}

\section{Consolidado das Propostas dos Grupos para Plenária Final}

São Paulo, 10 de outubro de 2003.

(as propostas abaixo foram votadas $\mathrm{e}$ aprovadas até $\mathrm{o}$ item $\mathrm{f}$, as restantes, a partir de $\mathrm{g}$, foram levadas para a segunda parte da Plenária Final a ser realizada em 29/11/2003)

\section{a) Centro de Referência em Segurança Alimentar:}

a) Formação do centro de referência com participação de todas as Secretarias em Segurança Alimentar e Nutricional em cada Subprefeitura com dotação própria e formação intema de conselhos regionais ou fóruns de Segurança Alimentar e Nutricional, participando a Sociedade Civil, Governo e Organizações Sociais. Oferecendo: cursos de segurança alimentar, grupos de geração de renda, alimentação para Comunidades locais, postos de venda de alimentos com menor custo (do produtor direto ao consumidor), implementação de Horta Municipal Urbana, Horta Escolar, desenvolvimento da feira solidária, banco de alimentos e incentivo ao crédito (grupo 1).

a) Criação de Centros de Referência em Segurança Alimentar e Nutricional em todas as Subprefeituras do municipio, com cursos de aproveitamento integral de alimentos de forma permanente, com trabalho voluntário e formação de multiplicadores da própria comunidade (grupo 2).

a) Se acatado os centros de referência em segurança alimentar e nutricional nas 31 Subprefeituras, possa ser instituido uma comissão gestora que tenha um terço (1/3) dos membros da comunidade e movimentos sociais, com assessoria técnica da PMSP (SAS e outras), para gestão dos programas/cadastros nas regiões. (grupo 3)

a) Implementar os Centros de Referência em Segurança Alimentar nas 31 Subprefeituras (grupo 3).

a) Criação dos Centros de Referência de Segurança Alimentar e Nutricional nas subprefeituras, com participação de todas as Coordenadorias, tendo como enfoque à "educação nutricional", evitando o desperdício de alimentos (grupo 3).

a) Criação de centro de referência em Segurança Alimentar e nutricional em todas as Subprefeituras (grupo 3).

a) Formação de centro de referência de segurança alimentar nas 31 áreas administradas pelas Subprefeituras para favorecer um olhar mais detalhado a todos os aspectos que envolvem, a agricultura familiar, os excedentes de produção, disponibilidade, acesso, combate à pobreza, desperdicio, politicas de educação alimentar, nutricional, projetos e programas de qualificação, agentes multiplicadores e com apoio das Secretarias de Saúde, Educação, Meio Ambiente, Agricultura, Assistência Social apoiadas pelo Subprefeito local e estabelecendo parcerias com universidades, ONG's, comerciantes e produtores locais, respeitando e fortalecendo as iniciativas locais já existentes. (grupo 4). 
a) Criação de centros de referência em Segurança Alimentar e Nutricional em todas as Subprefeituras.

a) Implantação de centros de referência em segurança alimentar, nas 31 áreas administradas pelas Subprefeituras, através da articulação de uma rede local envolvendo diversas secretarias, empresas e organizações sociais em apoio ao trabalho de formação de agentes multiplicadores da politica local de segurança alimentar. (Grupo 5)

a) Uma criação de Centros de Referência em Segurança Alimentar e Nutricional em todas as Subprefeituras. (Grupo 6)

a.1) Os restaurantes, cantinas (inclusive escolares) bares e fast Food devem expor em cartazes bem visíveis o valor nutricional similar a legislação dos produtos embalados, dos produtos vendidos direto para 0 consumidor (venda de balcão, produtos não embalados); juntamente devem mencionar alertas quando se tratar de alimentos potencialmente novos se consumidos em excesso, com menção dos agravos à saúde (Grupoll).

a.1) Padronizar a informação Nutricional das embalagens de maneira que permita a leitura a qualquer cidadão. (Grupo 11)

a.1) Uso indiscriminado de adoçantes pela população. Proponho maiores informações na rotulagem quanto aos possiveis perigos. (Grupo 11 )

a.2 Propor aos órgãos de registro de alimentos que sejam mais criteriosos quando de liberação de produção e comércio de certos tipos de alimentos. Vemos no comercio inúmeros produtos sem valor nutritivo com grande campanha na mídia atingindo crianças e adolescentes, dificultando a implantando bons hábitos alimentares. $\mathrm{E}$ ainda, trabalhar por campanhas pró-alimentação saudảvel. (Grupo 5)

a.2) Constar nos rótulos de sucos de frutas se o produto é ou não pasteurizado, ou esterilizado comercialmente. (Grupo 6)

a.2) Disponibilizar ao consumidor informações relativas às categorias de alimentos que estão sujeitos a registro ou isentos de registro e quais são os órgãos oficiais responsáveis por esta atividade. (Grupo 5)

a.2) Embalagens: Há que se ter segurança total ao usuário, quando do seu manuseio - abertura de tampas metálicas.

a.2) Implantação de uma rede capaz de absorver as políticas de Segurança Alimentar com as Secretarias envolvidas como SEMAB, SAS, SMS, SME, Subprefeituras, Ongs e Entidades representativas dos movimentos sociais envolvidos com o tema.

a.2) Legislação que determine número mínimo de profissionais de vigilância sanitária por mil habitantes para garantir a fiscalização alimentar de todos os estabelecimentos de interesse à saúde. (Grupo 11)

a.2) Necessidade de legislação mais moderna. Proponho apresentarmos proposta de legislação sanitária, com diretrizes duras a ser encaminhado à câmara Municipal de São Paulo, para modernização dos termos prioritários discutidos nesta 11 conferencia Municipal de Saúde.

a.2) Obrigatoriedade dos Produtores: (desde a origem até processamento final dos alimentos) $1^{\circ}$ ) produção de alimentos saudáveis. $2^{\circ}$ ) indicação de todos os produtos químicos adicionados no produto. $3^{\circ}$ ) colocar no 
rótulo todas as informações de aditivos químicos, origem do produto, riscos para a saúde, beneficios se consumido. $4^{\circ}$ ) Constar nos rótulos à quantidade em (g) gramas ou (ppm) partes por milhão de aditivos. (Grupo 6)

a.2) Proibição de propaganda de obras e eventos que intercedem em vigilância sanitária e sim divulgação dos direitors da população em vigilância sanitária (Grupo 11).

a.2) Proponho que sejam implantadas melhorias sanitárias e estruturais em todas as feiras livres para que haja segurança na distribuição de alimentos, conservação adequada dos alimentos pereciveis e condições satisfatórias para a higiene dos manipuladores e do meio ambiente. (Grupo 11)

a.2) Proposta de reintegração dos agentes vistores nas ações de Vigilância em Saúde conforme sua competência legal. (Grupo 11)

a.2) Quanto a produção, fazer com que tenha um maior número de esclarecimentos para o

a.2) Quanto à comercialização, fazer com que tenha um maior número de esclarecimentos para o consumidor: obrigatoriamente a data bem clara para que os idosos possam ler as validades. (observar este item)

a.2) Quanto às cames embaladas (fracionadas ou homogeneizadas) e embutidas fracionadas, vendidas em supermercados, deveria exigir rotulagem incluindo validade (relacionada ao rotulo original) lote, marca, origem (produtor), parte/corte de came, temperatura de armazenamento (Grupo 6)

a.2) Que além da informação nutricional da lei atual, as embalagens de alimentos tivessem identificação quanto ao nivel calórico desproporcional aos demais nutrientes.

a.2) Que os estabelecimentos varejistas (bares, restaurantes, lanchonetes, mercados, padarias e etc.) sejam obrigados a informar os ingredientes dos alimentos de fabricação própria, comercializados de forma clara e acessivel, para evitar o consumo de alimentos impróprios por parte de pessoas com restrições alimentares. (Grupo 6)

a.2) Que se crie uma lei de reaproveitamento de alimentos sem responsabilizar os doadores. (Grupo 11)

a.2) Rotulagem mais clara com informações básicas como composição e data de validade mais visivel. Um controle mais rigoroso de embalagem danificada. (Grupo 6)

a.2) Rotulagem, que haja de forma legivel, o nome completo, qualificação técnica e número de seu registro no órgão competente, do responsável técnico pelo produto envasado, sob pena da empresa e seus diretores responderem civil e criminalmente pelo ato. (Grupo 6)

a.2) Utilizar mecanismos de diferenciação por embalagens entre bebidas lácteas e leite e derivados, evitando com isso o engano na aquisição. (Grupo 6)

a.3) Campanha esclarecedora maciça à população sobre alimentos transgenicos. (Grupo 6)

a.3) Mobilizar a sociedade representada pelo COMUSAN e co-irmãs para interpelar o governo frente a sua atitude liberando os transgênicos pelas consequências irreparáveis. 
a.3) Os produtos que contenham transgenicos como leite de soja e queijos japoneses devem ser discriminados em rotulagem. (Grupo 6)

a.3) Produtos cámeos provenientes de animais alimentados com rações contendo transgenicos deverão ter obrigatoriedade de constar do rótulo tal informação. (Grupo 6)

a.3) Que haja obrigatoriedade de identificação no rótulo dos alimentos a presença de produtos transgênicos, tendo em vista a atual liberação no plantio destes. (Grupo 6)

a.4) Apoio à criação de creches 24 horas.

a.4) Apoio para a incubação de cooperativas e cursos profissionalizantes nas entidades.

a.5) Criação de um fundo municipal de combate à pobreza, com controle social.

b) Educação Nutricional:

b.1) Encaminhar a conferência Estadual propostas de melhoria da qualidade nutricional das cantinas escolares estaduais e particulares. Criação da disciplina de Segurança Alimentar e Nutricional na grade curricular (grupo 1).

b.2) Incluir na grade curricular o tema transversal da segurança alimentar e nutricional na educação infantil, e ensino fundamental (grupo 1).

\section{b.3) Suprimido}

b.4) Promover educação nutricional para população na área de educação em parceria com as Subprefeituras, SEMAB e demais Secretarias do municipio.

Criar uma Comissão dentro do COMUSAN para incentivar e fiscalizar a utilização das leis vigentes relacionadas a Segurança Alimentar, controle de doenças transmitidas por alimentos, zoonoses, higiene na manipulação de alimentos e prevenção da obesidade. Esses temas devem perpassar todas as fases, do ensino, envolvendo todas as matérias curriculo (transversalidade). (Grupo 5

b.5) Sensibilizar a iniciativa privada participante do PAT quanto a segurança alimentar do trabalhador com restrição alimentar ( celiacos, diabéticos, fenilcetunúricos e hipertensos) na relação dos itens da cesta básica e promover palestras sobre estas patologias ( grupo 1).

b.6) Obrigatoriedade do Programa de Educação Nutricional/Alimentar em equipamentos das Subprefeituras tais como: Coordenadorias de Educação, Saúde, Assistência Social, Abastecimento e outros utilizando profissionais da área, parcerias com Universidades e Escolas Técnicas ( grupo 2).

b.7) Educação nutricional com ênfase na Regra do REC (alimentos reguladores, energéticos e construtores) através de palestras e folhetos, instrutivos em Escolas, Postos de Saúde, mercados e pastorais da familia e da criança independente do nivel econômico-financeiro, todos devem ter acesso à proposta ( grupo 3).

b.8) Buscar a obrigatoriedade do ensino de segurança alimentar para as escolas do municipio ( grupo 3 ).

b.9) Implementar campanhas permanentes de segurança alimentar: rádio e televisão ( grupo 3). 
b.10) Implementação da Educação Nutricional nas escolas municipais e particulares ( grupo 3).

b.11) Criar programa de educação nutricional aplicados em comunidade - Sociedade Civil (grupo 3).

b.12) Segurança alimentar e nutricional ser disciplina nas escolas municipais, estaduais e até mesmo particulares. Trazer a consciência das crianças o que deve comer. (grupo 3 ).

Exigir a competência de "Educação Alimentar" a partir da iniciação escolar (creches, EMEI, EMP e segundo grau), dentro da grade curricular. ( grupo 3).

b.13) Suprimido

\section{b.14) Suprimido}

b.15) Criação de projetos e programas de educação alimentar para população pelo governo, atingindo a mídia, escrita e falada. (grupo 3).

b.16) Fomentar ações pedagógicas de esclarecimento ao consumidor enfocando no ensino fundamental a importância de uma alimentação saudável, evitando o desperdicio dos alimentos. Também auxiliar quanto aos valores que embasam a escolha do consumidor no momento da compra dos alimentos. A mídia deve ser utilizada como veiculo para informação de uma alimentação saudável uma vez que as informações atuais influenciam na escolha de alimentos menos saudáveis (grupo 4)

b.17) Divulgar em todos os meios (comercio; escola; supermercados; ambientes de trabalho) orientações básicas de higiene de alimentos e de uma alimentação saudável. (Grupo 5)

b.18) Implantar no calendário escolar das redes públicas e privadas a disciplina de segurança alimentar e nutricional, como forma de estar aprofundando e divulgando o tema durante todo o periodo escolar. Implantar treinamento de professores do ensino fundamental para uma orientação de uma alimentação saudável, com consumo consciente promovendo a prevenção de riscos e de doenças na idade adulta.

b.19) Inclusão nos currículos escolares dos níveis fundamental, médio e infantil noções de:

b.20) Introdução da Disciplina Educação Nutricional, Sanitária e noções básicas de prevenção de acidentes no curriculo escolar, desde a Pré-Escola até o Término do $2^{\circ} \mathrm{grau}$, com aulas práticas e teóricas. (Grupo 6)

b.21) Que a Secretaria Municipal de Assistência Social inclua em seu calendário de atividades, oficinas, seminários, entre outros com as familias assistidas em suas mais diversas áreas de atuação, sobre Segurança Alimentar e Nutricional.

b.22) Que o COMUSAN incentive e viabilize a elaboração de materiais para esclarecer o consumidor (contando com a colaboração dos próprios representantes de entidades que compõem o COMUSAN) sobre COMO interpretar os dizeres obrigatórios dos rótulos dos alimentos. (Grupo 5)

b.23) Realizar parcerias entre Setor Público (Vigilância Sanitária), Universidades e os meios de comunicação (TV, rádio, etc.), inserindo, no conteúdo de programas já existentes (como programas culinários), informações sobre segurança alimentar e higiene, doenças transmitidas pelos alimentos e seus meios de prevenção.

c-) Alimentação Escolar: 
c.1) As escolas devem incentivar uma alimentação sadia, criando novo hábito alimentar e nutricional, inclusive nas cantinas escolares estaduais e particulares.

c.2) Monitoramento dos alimentos fomecidos nas cantinas. (Grupo 3).

c.3) Inclusão de cantinas escolares estaduais e particulares.

c.4) Fazer cumprir a portaria para que as cantinas das escolas do municipio que pertencem a rede estadual e particular somente tenham produtos saudáveis na prevenção da obesidade e desnutrição, evitando salgadinhos, produtos gordurosos, etc. (grupo 4).

c.5) Questão da Merenda Escolar: melhoria da qualidade e do fomecimento em todos os horários das escolas públicas, principalmente estaduais.

Grupo 06

consumidor: Obrigatoriamente a data bem clara para que os idosos possam ler as validades. (Grupo 6)

d-) Restaurantes, Cozinhas, Café:

d.1) Ativação de restaurantes populares no Municipio de São Paulo. (grupo 1).

d.2) Buscar parceria e apoio, para a implantação de cozinhas comunitárias em área de elevada vulnerabilidade social. (grupo 3).

d.3) Estimular a criação de Restaurantes Populares e/ou comunitários em todas as regiões buscando parcerias com entidades (ONGS), com formecimento de café da manhã, almoço e jantar, com controle social. (grupo 3).

d.4) Potencializar as cozinhas dos serviços sociais para confecção de refeições nos finais de semana pelas e para as familias das comunidades (grupo 4).

d.5) Desenvolvimento de ações locais de inclusão social para atender as familias desempregadas, idosos, doentes, como: hortas comunitárias, restaurantes populares (grupo 4)

d.6) Espaço nas Subprefeituras para uma cozinha profissionalizante que fosse utilizado pela comunidade com fiscalização. (Grupo 6)

d.7) Que seja criado incentivo para Comunidades e Entidades para construção de restaurante popular em suas comunidades com fornecimento de café da manhã, almoço e jantar, com controle social.

d.8) Que seja incentivo de assistência a implantação de cozinhas comunitárias dentro das Subprefeituras e Entidades interessadas e envolvidas nos assuntos para geração de renda.

Da mesma forma as embalagens devem ter suas formas redondas, sem arestas que possam causar acidentes. (Grupo 6)

Entidades.

Enviar resultados da comusan a câmara do Municipio.

Ex.: Faixa verde: aveia, cames magras, queijos lights; Faixa amarela: cereais refinados, iogurtes com corantes; Faixa vermelha: cames gordas, bolachas recheadas, batatas tipo chips, refrigerantes. (Grupo 11)

e-) Fornecimento de alimentos a baixo custo: 
e.1) Isenção de impostos sobre os alimentos da cesta básica. (Grupo 1)

e.2) Estudo de propostas de politicas e mecanismos que visem diminuir o preço final do produto ao consumidor. Criar o Supermercado Popular: Órgãos Governamentais e da Sociedade Civil comprariam os alimentos diretamente do agricultor, acabando com o atravessador. Assim o alimento para este tipo de supermercado pode chegar mais barato. Que os mercados populares sejam criados próximos aos mais necessitados, uma vez que os mesmos não têm meios de locomoção (grupo 2)

e.3) Buscar o fortalecimento dos canais alternativos de fornecimento de alimentos: sacolões, banco de alimentos, etc. e ampliar os gêneros alimenticios oferecidos. (grupo 3)

e.4) Suprimido

e.5) Que a prefeitura adotasse os produtos para o abastecimento do pequeno produtor. (grupo 3)

f-) Pesquisa:

f.1) Verificação dos dados relacionados à SAN no âmbito das subprefeituras para se chegar ao " mapa da insegurança alimentar" (Grupo 1).

f.2) Estabelecer parceria do COMUSAN com instituições públicas ou privadas de ensino/pesquisa para avaliação dos programas governamentais destinados à Segurança Alimentar e Nutricional, contribuindo para o controle social da destinação dos recursos públicos (Grupo 2).

f.3) Suprimido

f.4) Suprimido

f.5) Fomentar pesquisas sobre agricultura urbana orgânica ou não, alcançando sua real viabilidade e aplicação visando a construção de manuais e orientação para o eventual agricultor urbano (exemplo: cultivar temperos antioxidantes ao invés de hortaliças, utilizar materiais recicláveis, ao invés de industrializados., etc.) (Grupo 4).

g-) Banco de alimentos descentralização:

g.1) Que o Banco de Alimentos seja descentralizado para as Subprefeituras, e que sua Coordenação, além de um técnico da área seja exercida por um Conselho Gestor da comunidade, o que facilitaria assim a entrega de alimentos, já com base em segurança alimentar, e acabariam os desperdícios (Grupo 2).

Espaço nas Subprefeituras para organização de fóruns de S.A.N., com "Banco de Alimentos" (poderiamos começar com espaços regionais - norte, sul, leste, oeste e centro). (Grupo 5)

h-) Apoio a reforma agrária:

h. 1) Apoio à reforma agrária ( grupo 3)

h.2) Estabelecer uma Política Pública Municipal visando uma parceria com as Cooperativas populares que produzam diversos tipos de alimentos de qualidade. 
i-) Agricultura urbana, periurbana e hortas comunitárias

i.1) Levantamento e identificação de áreas disponiveis para produção agricola nas áreas públicas e privadas urbanas e periurbanas, visando a busca de informações e dados que permitam viabilizar uma política para implementação de produção de produtos nas áreas citadas. (Grupo 5)

i.2) Que o incentivo às hortas urbanas só seja concedido para produtores que previamente se capacitem em produção e manipulação de alimentos saudáveis. (Grupo 6)

i.3) Incentivo do Governo Municipal à Agricultura Urbana (Grupo 1).

i.4) Estímulo e ampliação da ocupação de espaços públicos com agricultura urbana/hortas comunitárias, garantindo a participação da sociedade civil em parceria com o poder público com assessoria técnica e financeira. Criação de programas de feiras solidárias em todas as Subprefeituras. 0 programa deverá dar destaque a orientação dos feirantes para a participação no programa. Garantir que os mecanismos já existentes de punição para o desperdicio de alimentos seja aplicado (Grupo 2).

i.5) Dois dos principais problemas da agricultura urbana e periurbana estão no consumo de água necessário para produção, visto que já é caótico para o consumo da população humana e o destino final do lixo proveniente (grupo 4).

i.6) Criar uma estrutura governamental que dê o total suporte para o desenvolvimento organizado da agricultura urbana e periurbana, incluindo: orientação do que produzir, como produzir, preservando a qualidade da água e do solo, como comercializar, como conseguir suporte financeiro para a compra de sementes e locais de comercialização (grupo 4).

i.7) Que as Subprefeituras criem espaços para sacolões nas suas regiões privilegiando os produtores locais da agricultura familiar, garantindo um transporte mais barato e a qualidade final do produto, além de baixar custo e fortalecer a agricultura local (grupo 4).

i.8) Política de agricultura orgânica seja viabilizada, oferecendo conhecimento técnico e subsídio para os da agricultura orgânica, pois o solo precisa de descanso de pelo menos três anos. A garantia de subsídios para estas familias deverá ser garantida, já que não podemos mais poluir o solo e nossos aqüíforos subterrâneos (grupo 4).

j) Alimentos adequados às faixas etárias e portadores de patologias:

j.1) A necessidade de se consolidar ações de alimentação e nutrição no âmbito do SUS, em especial no modelo de atenção básica de saúde e da familia a investigação de doenças relacionadas a alimentação e erros inatos do metabolismo.

j.2) Agilizar a implantação de programas de alimentação específicos para portadores de patologias com restrição alimentar nas escolas e creches municipais e realizar parcerias com entidades representativas destas doenças para promover educação nutricional ( grupo I).

j.3) Garantir que nos programas de formecimento de alimentos a equipamentos sociais no municipio de São Paulo se atenda as caracteristicas e necessidades nutricionais de cada faixa etária, principalmente no caso de idosos (grupo 2). 
k) Vigilância:

k. 1) Criação e Implantação do Sistema de Vigilância Alimentar e Nutricional do Município de São Paulo para identificação e mapeamento dos agravos relacionados a Nutrição e educação. (Grupo 11)

k.2) Dar maior ênfase à fiscalização higiênico-sanitária e de segurança do trabalho em pequenas e médias empresas do ramo alimentício.

k.3) Implantação do sistema de vigilância mutricional no municipio.

k.4) Para que a vigilância sanitária seja mais rigorosa com os supermercados, restaurantes, açougues, etc. para que não deixem produtos com datas

k.5) Proponho a extinção de abate não industrial em avícolas dentro do município de São Paulo por se tratar de atividade que polui o meio ambiente e afronta o Direito a vizinhança, o Direito Ambiental, o Direito de Consumidor, o Direito Penal, o abate humanitário e principalmente, expõe a alto risco a saúde de consumidor, sendo inoportuna a aprovação de qualquer norma que teste regulamentar esta atividade diante das inúmeras irregulares envolvidas neste processo. (Grupo 11)

k.6) Que a PMSP desenvolva Programas de verificação da segurança dos alimentos disponíveis à população da capital de São Paulo e divulgue estes resultados. (Grupo 5)

k.7) Implantar ações de vigilância nutricional junto à população de risco (crianças) matriculadas nas creches e escolas municipais ( grupo 1).

k.8) Implantar ações de vigilância nutricional junto à população de risco (crianças) matriculadas nas creches e escolas municipais. (Grupo 1)

1) Não ao desperdicio/consumo consciente:

1.1) Criação de uma comissão para estudo para aprimoramento de legislação que viabilize o aproveitamento de sobras de alimentos de restaurantes, hotéis e similares, de maneira que possa dar orientação aos respectivos doadores para a conservação e preservação das sobras limpas.

1.2) Instalação das feiras solidárias em todas as Subprefeituras. Questão da merenda escola, melhoria da qualidade e do fomecimento em todos os horários das escolas. (Grupo 6)

1.3) Instituir programas de educação e conscientização da população e do poder fiscalizador par que não haja desperdicio de alimentos em geral quando estes estiverem próprios para o consumo. (Grupo 11)

1.4) Elaborar programas de consumo consciente dos alimentos visando o desperdício de alimentos e o excesso de consumo - em todas as instâncias da sociedade civil. (Grupo 3)

1.5) Instalação das feiras solidárias em todas as Subprefeituras. (Grupo 3)

m) Direito Humano à Alimentação 
m.1) Incentivo ao desenvolvimento de programas de Segurança Alimentar e Nutricional e direito humano à alimentação dentro das entidades que compõe o conselho municipal de Serviço de Alimentação e NutriçãoSAN. (Grupo 1).

n) Cardápio/Embalagens adequadas à deficientes visuais:

n.1) Atender o cumprimento da Lei de cardápio para deficientes visuais nas lanchonetes, churrascarias, e restaurantes etc... (Grupo 1).

n.2) Embalagens padronizadas para os produtos dietéticos escritos em braile, com nome do produto e validade. (Grupo 6)

Nosso laboratório hoje consegue fazer algumas avaliações quanto a qualidade da água com número de amostras reduzidas. (Grupo 11)

\section{o) Feiras e Mercados}

o.1) Adequação numérica do quadro de profissionais, responsáveis pela fiscalização sanitária, para que ocorra um monitoramento mais eficaz, garantindo a qualidade dos alimentos consumidos pela população. $O$ número de profissionais que atuam (médicos veterinários, nutricionistas, médicos sanitaristas, etc.) é inadequado à demanda. Não há segurança alimentar sem monitoramento.

o.2) Transferir as feiras livres das ruas de São Paulo para locais fechados especificos para a comercialização de alimentos (galpões como os sacolões). A exposição dos alimentos de origem animal à renda em temperatura ambiente e exposto à poeira e insetos por 6 horas compromete a qualidade sanitária. Os residuos acumulados nos bueiros favorecem a proliferação de ratos e colocam em risco as residências e os estabelecimentos comerciais da região. A falta de sanitários obriga os feirantes a fazerem suas necessidades na própria rua ou em canteiros das residências e não há como higienizarem as mãos. (Grupo 5)

o.3) Melhoria da fiscalização nas feiras e mercados. (Grupo 1).

p) Refeições sobre rodas

p. 1) Criação nas Coordenadorias de Saúde das Subprefeituras do Programa Refeição sobre rodas, para atender os idosos dependentes e que necessitem de ter 0 acesso ao alimento com qualidade e quantidade suficiente, proporcionando saúde e qualidade de vida. (Grupo 3)

q) Cesta Básica:

q. 1) Efetivar convênio da Prefeitura com instituições do $3^{\circ}$ setor com distribuição de cestas básicas em troca da participação da Comunidade adulta em cursos que facilitem a inclusão no mercado de trabalho.(Grupo 1)

q.2) Incluir nas cestas básicas produtos de Higiene pessoal e Limpeza (separados). Centro de Referência alimentar nas prefeituras. (Grupo 5)

r) Decreto:

r.1) Criar lei municipal para que o COMUSAN tenha caráter deliberativo, tendo em vista as dificuldades de execução dos projetos que são propostos pelo mesmo. 
r.2) O governo Municipal deve agilizar junto a Câmara Municipal à aprovação da Lei que confere ao COMUSAN caráter deliberativo, presidência da sociedade civil e a Secretaria Geral do Govemo. (Grupo 1)

s-) Monitoramento:

s) b4

t-) Capacitação de profissionais da área:

t.1) Aumento do número de cursos de capacitação e formação para todos os trabalhadores que manipulam alimentos, ministrados por entidades habilitadas.

t.2) Capacitar os conselheiros e líderes das comunidades e entidade da Sociedade Civil na questão de segurança alimentar para melhor desempenho da sua atividade. (Grupo 6)

t.3) Capacitar os profissionais da área de saúde (de hospitais, postos de saúde, clínicas médicas e congêneres) a diagnosticar bem como notificar as enfermidades transmitidas por alimentos visando a redução da taxa de sub-notificação destas doenças.

t.4) Maior esclarecimento aos produtores de alimentos sobre as diversas patologias com restrições alimentares para que a rotulagem dos alimentos contenha informações mais precisas sobre todos os ingredientes do produto. (Grupo 6)

t.5) Uso de defensivos agricolas naturais, mediante orientação e treinamento do produtor. (Grupo 6)

t.6) Que sejam criadas pelo menos " 4 casas de agricultura" nas regiões norte, sul, leste e oeste, para dar apoio técnico e subsidio à agricultura familiar, facilitando a informação, troca de experiência, insumos e materiais, facilitando a vida dos agricultores familiares (grupo 4).

t.7) Ao incentivo da agricultura familiar dever-se-á juntar informações e acompanhamento técnico ao que tange à contaminação, solo, água e ar, que enfim sejam observadas primeiro o saneamento básico (grupo 4).

u) Responsabilidade técnica / Recursos humanos:

u.1) Para auxiliar no combate à obesidade, desnutrição e outras carências nutricionais, proponho que todo posto de saúde tenha no seu quadro funcional pelo menos um técnico em nutrição e dietética - requisitados por meio de decretos municipais e estaduais respeitando as atribuições exercidas a cada profissão. (Grupo 11)

v) Educação ambiental / Preservação:

v.1) Promover, através da educação ambiental a conscientização da comunidade social, no espaço próprio deles.

v.2) Solicitar à ABia estudos com a finalidade de substituir todas as embalagens de alimentos processados por embalagens recicláveis com a finalidade de gerar renda a população carente e diminuir a poluição ambiental. (Grupo 5) 
w)Politicas públicas:

w.1) A unificação dos programas sociais do município (bolsa-escola, alimentação, Peti, auxílio-gás, renda minima, etc... aderindo proposta do Governo Federal "bolsa familia".

w.2) Criação de laboratórios equipados não só para investigação de alimentos mas também para o aperfeiçoamento das investigações de surtos como o PCR e outras tecnologias extremamente importantes para investigações dos ambientes quanto nas pessoas.

w.3) Fomentar a criação de grupo multidisciplinar junto as Coordenadorias de saúde local para atuar em ações de prevenção as Doenças Transmitidas por Alimentos, investigação de surtos, aspectos sócio-ambientais de riscos, campanhas educativas de prevenção. (Grupo 11)

w.4) Quanto ao programa FOME ZERO: 1 -Enfatizar a necessidade de municipalizar o Fome Zero com um programa FZ São Paulo; 2 - Priorizar o atendimento aos munícipes de São Paulo para S.A.N. garantido: quantidade, qualidade e regularidade; 3 - Envolver Subprefeituras, Secretarias (Saúde, SAS, Educação, etc.) para cadastrmento de pessas e familias com carências. 4 - Definir Programas de S.A.N. (refeitórios comunitários, refeições a domicílio, cestas básicas, restaurantes populares). 5 - Envolver instituições filantrópicas no programa. 6 - Coordenar com Associações de Supermercados e varejistas a coleta de doações para Bancos de Alimentos (do publico e prestes a vencer nos Supermercados). 7 - Utilização de imóveis do patrimônio municipal, isenção de taxas. 8 - Estimular voluntariado.

w.5) Ser implantado pelo governo um sistema de divulgação para o uso de alimentos orgânicos e barateamento no seu custo, uma vez que o seu consumo é o melhor para o ser humano e assim os residuos impactantes será menor, beneficiando o meio ambiente. (Grupo 5)

$\mathrm{x}-$ ) Incentivos:

x.1) Integração da cadeia de valores, através de acompanhamento sistemático, desde a produção de alimentos (origem, meio ambiente, responsabilidade social, embalagem, uso de recursos renováveis e não agressivos), transporte, distribuição e manipulação. $O$ acompanhamento deve ser exercido por entidades certificadoras credenciadas pelos Governos / Autoridades Públicas, atuando como base em normas nacionais e internacionais (grupo 4).

x.2) Criação de cooperativas a fim de gerar renda para que as pessoas possam se alimentar melhor. Essa cooperativa deverá ter incentivo do Governo (grupo 4).

$x .3)$ Aproximar as entidades de defesa do consumidor às associações de moradores de bairros com incentivo governamental (Municipal) de esclarecer a população enquanto consumidores sobre a questão de segurança alimentar.

$\mathrm{x}$ 4) Elaborar um selo de qualidade municipal para produtores que queiram agregar valor aos seus produtos que seguem requisitos mínimos de qualidade caracterizados por legislação vigente. Elevando assim a preocupação com a produção de qualidade e tendo o retorno conceitual e financeiro garantido.

x.5) Incentivos fiscais às organizações em geral na redução comprovada do desperdício de alimentos. 
x.6) Incentivos fiscais para empresas que adotarem de fato a reciclagem de embalagens, seja aluminio, papel ou vidro. (Grupo 5)

x.7) Que o govemo crie um plano / proposta de insentivo para industrias de alimentos e fast-food para ajudar em projetos através de patrocínios, palestras e cursos dirigidos à população em geral. Esta proposta deve ser divulgada através da midia, diários oficiais, entre outros. (Grupo 5)

x.8) Que o Governo Municipal dê incentivo fiscal para que as Indústrias Alimentícias produzam alimentos específicos para os portadores de patologia, com restrições alimentares. (Grupo 6)

y-) Controle social:

y.1) Que as consultas do Legislativo Municipal para projetos de lei da área de segurança alimentar sejam encaminhadas ao COMUSAN para consulta e parecer (grupo 4).

y.2) Conferir poderes de "fiscalização" de forma a implementar o que estabelecido no artigo 196 e seguintes da CF, à organismos de entidade da Sociedade Civil Organizadas nas politicas de vigilância sanitária das esferas municipais, estaduais e federais, nos moldes do que já vêm ocorrendo no meio ambiente, através de ONGs credenciadas. (Grupo 11)

y.3) Participação do COMUSAN no acompanhamento do projeto de Lei - PL 0366/2002 - Código Municipal de Controle de Vetores e Pragas Sinantrópicas, podendo assim contribuir na discussão que vem ocorrendo.

z) Cadastro único:

z.1) Apoio ao cadastro único para os programas sociais com critérios transparentes, melhores distribuições e controle social. (Grupo 6)

z.2) Criação de cadastro único para os programas sociais tendo em vista que o Governo Municipal e Estadual beneficia mais uns em detrimento dos outros.

Para esclarecimento:

1. Desenvolver ações locais integradas às iniciativas do Governo Federal quanto à descentralização da Secretaria Municipal de Abastecimento (grupo 4).

2. Buscar a descentralização dos entrepostos de alimentos (grupo 4). 


\section{Anexo 13}

Tabela C : Conselheiros participantes das reuniões do COMUSAN-SP, 2002 ( $\mathrm{N}^{\circ}, \%$, quorum)

Conselheiros Participantes por Reunião em 2002

\begin{tabular}{|c|c|c|c|c|c|c|}
\hline$N^{\circ}$ Reunião & $\begin{array}{c}\text { Data das } \\
\text { Reunióes }\end{array}$ & Titulares & Suplentes & $\begin{array}{c}\text { Suplentes } \\
\text { que } \\
\text { Assumiram }\end{array}$ & Quórum & $\begin{array}{c}\% \text { do } \\
\text { Quórum }\end{array}$ \\
\hline $1^{\circ}$ & $18 / 2$ & 31 & 17 & 2 & 33 & 82,5 \\
\hline $2^{\circ}$ & $14 / 3$ & 32 & 18 & 3 & 35 & 87,5 \\
\hline $3^{\circ}$ & $11 / 4$ & 26 & 15 & 5 & 31 & 77,5 \\
\hline $4^{\circ}$ & $19 / 5$ & 22 & 15 & 8 & 30 & 75 \\
\hline $5^{\circ}$ & $13 / 6$ & 21 & 17 & 6 & 27 & 67,5 \\
\hline $6^{\circ}$ & $11 / 7$ & 20 & 11 & 3 & 23 & 57,5 \\
\hline $7^{\circ}$ & $8 / 8$ & 21 & 13 & 5 & 26 & 65 \\
\hline $8^{\circ}$ & $12 / 9$ & 24 & 14 & 3 & 27 & 67,5 \\
\hline $9^{\circ}$ & $10 / 10$ & 21 & 14 & 7 & 28 & 70 \\
\hline $1^{\text {a }}$ & $7 / 11$ & 11 & 6 & 5 & 16 & 40 \\
\hline $1^{\circ}$ & $14 / 11$ & 18 & 4 & 4 & 22 & 55 \\
\hline $1^{\circ}$ & $12 / 12$ & 19 & 10 & 6 & 25 & 62,5 \\
\hline$M^{\circ}$ & & 25 & 13 & 5 & 27,9 & 69,8 \\
\hline
\end{tabular}

Fonte: listas de presença das reuniões ordinárias do COMUSAN-SP 


\section{Anexo 14}

Tabela D : Conselheiros participantes das reuniões do COMUSAN-SP, 2003 ( $\mathrm{N}^{\circ}, \%$, quorum)

\section{Conselheiros Participantes por Reunião em 2003}

\begin{tabular}{|c|c|c|c|c|c|c|}
\hline$N^{\circ}$ Reunião & $\begin{array}{c}\text { Data das } \\
\text { Reuniões }\end{array}$ & Titulares & Suplentes & $\begin{array}{c}\text { Suplentes } \\
\text { que } \\
\text { Assumiram }\end{array}$ & Quórum & $\begin{array}{c}\% \text { do } \\
\text { Quórum }\end{array}$ \\
\hline $12^{\circ}$ & $6 / 2$ & 21 & 12 & 5 & 26 & 65 \\
$2^{\mathrm{a}} \mathrm{E}$ & $17 / 2$ & 14 & 9 & 5 & 19 & 47,5 \\
\hline $13^{\circ}$ & $13 / 3$ & 19 & 13 & 8 & 27 & 67,5 \\
\hline $14^{\circ}$ & $10 / 4$ & 18 & 12 & 6 & 24 & 60 \\
\hline $15^{\circ}$ & $8 / 5$ & 20 & 15 & 7 & 27 & 67,5 \\
\hline Posse & $8 / 5$ & 27 & 18 & 3 & 30 & 75 \\
\hline 16 & $12 / 6$ & 22 & 16 & 6 & 28 & 70 \\
\hline $17^{\circ}$ & $3 / 7$ & 20 & 5 & 1 & 21 & 52,5 \\
\hline $18^{\circ}$ & $7 / 8$ & 17 & 14 & 4 & 21 & 52,5 \\
\hline $19^{\circ}$ & $11 / 9$ & 20 & 10 & 5 & 25 & 62,5 \\
\hline$\ldots$ & $\ldots$ & $\ldots$ & $\ldots$ & $\ldots$ & $\ldots$ & $\ldots$ \\
\hline MÉDIA & & 19,3 & 11,6 & 5 & 25,4 & 63,5 \\
\hline
\end{tabular}

Fonte: listas de presença das reuniōes ordinárias do COMUSAN-SP 


\section{Anexo 15}

Sistematização das Pautas de Reunião

\begin{tabular}{|c|c|}
\hline $\begin{array}{l}\text { Reunião/ } N^{0} \text { de } \\
\text { ordem/data/local }\end{array}$ & PAUTAS \\
\hline $\begin{array}{l}\text { A1-18/02/02- } \\
\text { FECOMÉRCIO }\end{array}$ & $\begin{array}{c}\text { *Instalação do COMUSAN } \\
\text { *Avaliação da I Conferência } \\
\text { *Oficialização do COMUSAN } \\
\text { *Eleger Secretaria Provisória do COMUSAN } \\
\text { *Discutir regimento interno do COMUSAN } \\
\text { *Fazer cronograma de reuniões } \\
\text { * Informes }\end{array}$ \\
\hline $\begin{array}{l}\text { A2-14/03/02- } \\
\text { SEMAB/DIMA }\end{array}$ & $\begin{array}{c}\text { *Leitura e votação das mof̧ões da I Conferencia } \\
\text { *Discussão do regimento interno do COMUSAN ( proposta da } \\
\text { comissão) } \\
\text { *Leitura da ata da } 1^{2} \text { reunião } \\
\text { *Calendário das reuniões do COMUSAN } \\
\text { *Informes }\end{array}$ \\
\hline $\mathrm{A} 3-11 / 04 / 02-\mathrm{ABONG}$ & 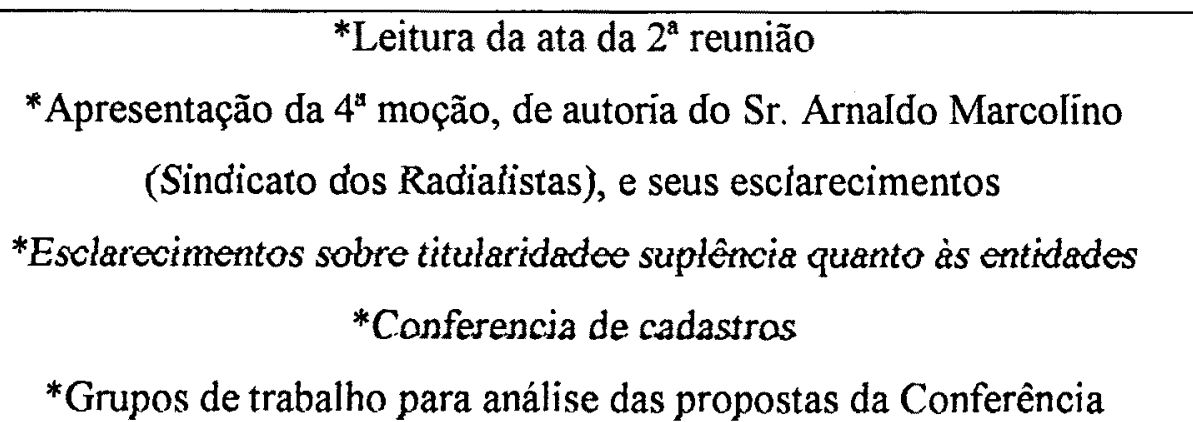 \\
\hline $\begin{array}{c}\text { A4-09/05/02 - } \\
\text { SINDEEA }\end{array}$ & $\begin{array}{c}\text { *Pedido do histórico das entidades } \\
\text { *Leitura da ata da } 3^{2} \text { reunião e votação } \\
\text { *Apresentação das propostas da I Conferência analisadas pelos GTs } \\
\text { *Informes da CE }\end{array}$ \\
\hline
\end{tabular}




\begin{tabular}{|c|c|}
\hline & $\begin{array}{c}\text { *Votação das propostas } \\
\text { *Proposta de Seminário para Conselheiros } \\
\text { *Convite para NUTRISOPA / CEAGESP } \\
\text { *URBIS } 2002 \text { e participação do COMUSAN } \\
\text { *Informes dos Conselheiros }\end{array}$ \\
\hline A5-03/06/02- APAS & $\begin{array}{c}\text { *Apresentação de proposta da SMS - Decreto } 41.660 / 02 \text { que } \\
\text { regulamenta a lei } 13.264 / 01 \\
{ }^{*} \text { Leitura da ata da } 4^{a} \text { reuniäo } \\
{ }^{*} \text { Encarrininamentos da CE } \\
{ }^{*} \text { Apresentação de nova Conselheira } \\
{ }^{*} \text { Apresentação dos relatórios dos GTs } \\
{ }^{*} \text { Informes dos Conselheiros }\end{array}$ \\
\hline A6-11/07/02-CRQ-4 & $\begin{array}{c}\text { *Leitura da ata da } 5^{2} \text { reunião } \\
\text { *Apresemtação das propostas aprovadas pelo COMUSAN-SP } \\
\text { *Relato da Experiência da Ass. Vh.Araguaia (Conselheiro) } \\
\text { *Relato da experiência do Instituto POLIS (Conselheiro) } \\
\text { *Dia Mundial da Alimentação } \\
\text { *Equipe de Informação } \\
\text { *Apresentação do Banco de Alimentos } \\
\text { *Informes dos Conselheiros }\end{array}$ \\
\hline $\begin{array}{l}\text { A7-08/08/02- } \\
\text { SEMAB/DIMA }\end{array}$ & $\begin{array}{c}{ }^{*} \text { Leitura da ata da } 6^{2} \text { reunião } \\
\text { *Exposição de trabalhos } \\
\text { a) Vila Araguaia (Conselheiro) } \\
\text { b)Banco de Alimentos (Coordenadora do Programa) } \\
\text { c)POLIS (Conselheira) } \\
\text { *Apresentação das propostas para dia mundial da alimentação } \\
\text { *Discussão sobre Seminário Democracia Participativa } \\
\text { *Informes dos Conselheiros }\end{array}$ \\
\hline
\end{tabular}




\begin{tabular}{|c|c|}
\hline A8 - 12/09/02 - SMS & $\begin{array}{c}\text { *Projetos prioritários de SMS (Coordenadora de Programas- SMS) } \\
\text { *Programa Bolsa Alimentação de SMS (Conselheira - SMS) } \\
\text { *Debate sobre a Água } \\
{ }^{*} \text { Comvidados } \\
\text { a)Pró-água / SES (Coordenadora do Programa) } \\
\text { b)Visão da Sociedade - Ação da Cidadania (Coordenador) } \\
\text { *Dia mundial da alimentação (Café da Manhã na Praça da Sé) } \\
\text {-preparativos } \\
\text {-divisão de tarefas } \\
\text { *Informes dos conselheiro }\end{array}$ \\
\hline $\begin{array}{c}\text { A9 - 10/10/02 - } \\
\text { SINDEEA }\end{array}$ & $\begin{array}{c}\text { *Apresentação do trabalho do Instituto POLIS } \\
{ }^{*} \text { Conselho de Gestão do Banco de Alimentos } \\
\text { *Projetos de SEMAB, descentralização e projetos sociais (Assessor do } \\
\text { Secretário) } \\
{ }^{*} \text { Dia Mundial da Alimentação } \\
{ }^{*} \text { Papel do COMUSAN - Doc } \\
\text { *Leitura da atas da } 7^{\mathrm{a}} \text { e } 8^{\mathrm{a}} \text { reuniões } \\
\text { *Seminário de Conselheiros (12 e } 13 / \text { / } 2 / 02) \\
\text { *Informes }\end{array}$ \\
\hline $\begin{array}{l}\text { A1 extraordinária - } \\
\text { 07/11/02 - POLIS }\end{array}$ & $\begin{array}{l}\text { *Apresentação do trabalho do Instituto POLIS } \\
\text { *Plano de metas } 2003 \text { (GTs partidários para plano de metas, dois grupos } \\
\text { A e B) } \\
\text { *Leitura das atas da } 7^{\circ}, 8^{\circ} \text { e } 9^{a} \text { reuniōes } \\
\text { * Eleição dos membros do COMUSAN para Banco de Alimemos } \\
\text { *Esclarecimentos de SEMAB-G sobre oficialização do conselho } \\
\text { (Assessor do Secretário) } \\
\text { *Encontro de conselheiros -CPP (20/11)- (dez vagas - eleger } \\
\text { representantes) } \\
{ }^{*} \text { Informes }\end{array}$ \\
\hline
\end{tabular}




\begin{tabular}{|c|c|}
\hline A10-14/11/02- POLIS & $\begin{array}{l}\text { *Apresentação das propostas dos GTs A e B, sobre o plano de metas } \\
\qquad 2003 \text { e votação } \\
\text { *Eleição dos dez representantes do COMUSAN para o encontro de } \\
\text { conselheiros } \\
\text { *Avaliação do Dia Mundial da Alimentação } \\
\text { *Informes } \\
\text { *Leituras das atas } 7^{\mathrm{a}}, 8^{\mathrm{a}}, 9^{\mathrm{a}} \text { e } 1^{\mathrm{a}} \mathrm{Ex} \text {. } \\
\text { *Seminário de conselheiros - programa minimo }\end{array}$ \\
\hline A11-12/12/02-POLIS & $\begin{array}{l}\text { *Avaliação dos trabalhos do COivUSAN em } 2002 \text { (formação de doís } \\
\text { GTs paritários) incluindo I Conferência } \\
\text { *Apresentação dos trabalhos } \\
\text { *Cronograma de reuniões para 2003-11-07 } \\
\text { *Apresentação da Implementação para } 2003 \text { Subprefeituras (Chefe de } \\
\text { Gabinete de SIS) }\end{array}$ \\
\hline A12-06/02/03-POLIS & $\begin{array}{c}\text { *Leitura da ata da } 11^{2} \text { reunião } \\
\text { *Decreto de criação do COMUSAN-SP } \\
\text { *GTs para execução do Plano de Metas } 2003 \\
{ }^{*} \text { Comissão para organizar a II Conferència } \\
\text { *Inversão das posições titulares e suplentes conforme previstos na I } \\
\text { Conferência } \\
\text { *Informes dos Conselheiros }\end{array}$ \\
\hline $\begin{array}{c}\text { A2-Extraordinária - } \\
\text { 17/02/03 - } \\
\text { SEMAB/DIMA }\end{array}$ & $\begin{array}{c}\text { *Decreto } 42.862 \text { de } 13 / 02 / 2003 \text { que institui o COMUSAN-SP num } \\
\text { comparativo com o texto original aprovado na } 1 \text { Conferência } \\
\text { * Discussão e encaminhamemtos } \\
\text { *Informes }\end{array}$ \\
\hline $\mathrm{A} 13-13 / 03 / 03-\mathrm{APAS}$ & $\begin{array}{l}\text { *Apresentação dos projetos tramitando na Câmara sobre criação de } \\
\text { Conselho de Segurança Alimentar e o Projeto de Lei 49/2001 } \\
\text { *Discussão dos mesmos e encaminhamentos } \\
\text { *Comissão para discutir alteração do decreto do COMUSAN }\end{array}$ \\
\hline
\end{tabular}




\begin{tabular}{|c|c|}
\hline & $\begin{array}{l}\text { *Evento para o lançamento oficial do COMUSAN - SP } \\
\text { *Banco de Alimentos X Fome Zero (Coordenador do Programa) } \\
\text { *Leitura das atas } 11^{*} \text { e } 12^{*}, 2^{*} \mathrm{EX} . \\
\text { *Relato dos Gis - Plano de Metas } 2003 \\
\text { *Informes } \\
\text { *Indicação dos conselheiros para o curso de formação da CPP }\end{array}$ \\
\hline $\begin{array}{c}\text { A14 -10/04/03 - } \\
\text { SindBares }\end{array}$ & $\begin{array}{c}\text { *Leitura e votação de moção pró-ACELBRA } \\
\text { *Leitura da }\left[3^{*} \text { ata }\right. \\
\text { *Retato dos Gts - plano de metas } 2003 \\
\text { *Evento de posse oficial do COMUSAN -SP / Decreto } \\
\text { *Mocão Soja transgênica - CE } \\
\text { *Relato da reunião da CE com Secretário } \\
\text { *Fórum de conselheiros (junho/2003) } \\
\text { *Curso de formação/ POLIS (14 conselheiros) - CPP (11 conselheiros) }\end{array}$ \\
\hline $\begin{array}{c}\text { A15-08/05/03 - Palácio } \\
\text { das Industrias }\end{array}$ & $\begin{array}{c}\text { *Apresentação de novos Conselheiros } \\
\text { *Discussão da Cerimônia de Posse do COMUSAN-SP } \\
\text { *Relatório dos Gts - Plano de Metas } 2003 \\
\text { *Estrutura da II Conferência de SAN } \\
\text { *Informe FISP }\end{array}$ \\
\hline
\end{tabular}

\begin{tabular}{|c|c|}
\hline A Posse do COMUSAN \\
$08 / 05 / 03$ - Palácio das \\
Industrias
\end{tabular}




\begin{tabular}{|c|c|}
\hline & ${ }^{*}$ Secretário encerra cerimônia SEMAB \\
\hline $\begin{array}{c}\text { A16-12/06/03- SEMAB- } \\
\text { G }\end{array}$ & $\begin{array}{c}\text { *II Encontro de Conselheiros } 16 \text { e 17/06/03 } \\
{ }^{*} \text { Carta de Principios Fórum Interconselhos } \\
\text { *Informes dos Conselheiros } \\
\text { *II Conferência de SAN (data de realização) } \\
\text { *Programa Fome Zero X Banco de Alimentos (corpo consultivo } \\
\text { do banco) }\end{array}$ \\
\hline AI $7-03 / 07 / 03$ & $\begin{array}{c}\text { *Participação do Secretário no Conselho } \\
\text { *Noção de apuio a ACELBRA }^{\text {*Participação no Corpo Consultivo do Banco }} \\
\text { *II Conferência (Programa/Convidados) } \\
\text { *FBSAN ( julho) } \\
\text { *Denuncia Sitio das Alamedas } \\
\text { * Informes }\end{array}$ \\
\hline A18 & $\begin{array}{c}\text { *II Conferencia de SAN } \\
\text { *Eechamento da Programação } \\
\text { *Balanço dos Patrocínios para apresentar na Conferência } \\
\text { * Informes }\end{array}$ \\
\hline A19 & $\begin{array}{c}\text { II Conferência de SAN } \\
\text { *Roteiro da Organização } \\
\text { *Relato das Grupas / Comissão } \\
\text { *Fechamento } \\
{ }^{*} \text { Informes }\end{array}$ \\
\hline
\end{tabular}

